\title{
The Strange Death of the Law Merchant - Part 2
}

\author{
Graham McBain ${ }^{1,2}$ \\ ${ }^{1}$ Peterhouse, Cambridge, UK \\ ${ }^{2}$ Harvard Law School, USA \\ Correspondence: Graham McBain, 21 Millmead Terrace, Guildford, Surrey GU2 4AT, UK. E-mail: \\ gsmcbain@aol.com
}

Received: April 11, 2016 Accepted: May 14, 2016 Online Published: June 11, 2016

doi:10.5539/ilr.v5n1p89 URL: http://dx.doi.org/10.5539/ilr.v5n1p89

\section{ADMIRALTY \& THE LAW MERCHANT ${ }^{520}$}

One area it was often said the law merchant applied was in early maritime courts.

- However, the law on such courts is scant and obscure and - while the law merchant may have been applied to some extent in these courts (as well as, later, in the High Court of Admiralty, 'HCA') - it is also likely the common law generally applied, save in cases where the customs of the local port made specific provision;

- In any case, all local maritime courts still extant were abolished 1835 - apart from the Warden's court of the Cinque Ports. Its jurisdiction was reduced in 1855 and, thus, only now survives as the Cinque Ports' Court of Admiralty which is obsolete, not having heard a case since 1914.

As to these matters:

\section{(a) Local Admiralty Courts: Cinque Ports}

The extent to which these existed is unclear. There appear to have been 9 English ports under the control of a warden in Roman times. ${ }^{521}$

- In the Anglo-Saxon period, Edward the Confessor (1042-66) may have granted a charter to the Cinque Ports (i.e. Hastings, Dover, Sandwich, New Romney and Hythe) or, possibly, just to Dover, Sandwich and Romney. However, this charter (although it was referred to in subsequent charters to the Cinque Ports) has been lost;

- $\quad$ For his part, after the Norman Conquest, William I (1066-87) may have created a palatine jurisdiction in respect of the Cinque Ports. One placed under a warden (gardien) who had his seat at Dover (and who became Constable of Dover castle). ${ }^{522}$

What does seem clear is that there was a local court - the Court of Shepway (or Shipway) ${ }^{523}$ which seems to

\footnotetext{
${ }^{520}$ See generally: (a) RG Marsden (ed), Select Pleas in the Court of Admiralty, SS, vol 6 ('Marsden I'); (b) JE Hall, The Practice and Jurisdiction of the Court of Admiralty (Baltimore, 1809)(it contains F Clerke, The Practice of the High Court of Admiralty (1667, taken from a collated edition of 1791); (c) Twiss, n 23; (d) ES Roscoe, Studies in the History of the Admiralty Court and Prize Court (1932, rep Professional Books Ltd, 1987); (e) W Senior, Doctors' Commons and the Old Court of Admiralty (Longmans, 1922); (f) R Watts, Practice of the Court of Admiralty in England and Ireland (1757); (g) FL Wiswall, The Development of Admiralty Jurisdiction and Practice since 1800 (Cambridge UP 1970); (h) RG Marsden, Law and Custom of the Sea (Naval Records Society, 2 vols, 1925) ('Marsden II'); (i) A Browne, A Compendious View of the Civil Law and the Law of the Admiralty ( $1^{\text {st }}$ American ed, 1840 from $2^{\text {nd }}$ ed, 1802); (j) H Spelman, The English Works of Henry Spelman (ed. Bishop of London, 1723); (k) TL Mears, The History of the Admiralty Jurisdiction, AALH, vol 2, pp 312-64; (1) Pritchard, n 218; (m) P Studer, The Oak Book of Southampton of c. AD 1300, vol 2 (Southampton Record Society, 1911); (n) J Reddie, An Historical View of the Law of Maritime Commerce (Blackwood, 1841)('Reddie I'); (o) J Reddie, Researches, Historical and Critical in Maritime International Law (Edinburgh, 1844)('Reddie II'); (p) J Reeves, A History of the Law of Shipping and Navigation (T Burnside, 1792): (q) DO Shilton \& R Holworthy, High Court of Admiralty Examinations 1637-1638 (Anglo-American Records Foundation Inc. 1932); (r) R Watts, The Practice of the Court of Admiralty (Dublin, 1757).

${ }^{521}$ McBain, n 50, p 93. W Camden, Britannia (1695 ed), p lxxvii 'The Count of the Saxon Shore, who was to defend the coast against the Saxons, and by Ammianus Marcellinus is called comes tractus maritimi, had seven companies of foot, two troops of horse, the second legion and a cohort under him'. See also Mears, n 520, p 314.

522 Ibid.

${ }^{523}$ This may have come from the location in the slipway (or way of the ships) in the port of Lympne, see McBain, n 50, p 111.
} 
have acted as a shire court for the Cinque Ports as early as 1150 and which, likely, also dealt with maritime matters. $^{524}$

- Demise of Court of Shepway. From, at least c. 1358, it seems that the Court of Shepwey became an appeal court ${ }^{525}$ and there developed a Warden's Court, sitting in Dover. However, it seems this judicial innovation was opposed by the portsmen and that admiralty matters, in particular, continued to be held on an ad hoc basis at the relevant place of the wreck or the port where the dispute was located; ${ }^{526}$

- Warden's Court: Maritime. This court dealt with chancery matters as well as acted as a court of admiralty (it appears to have encompassed both in one court). ${ }^{527}$ However, it may have existed as a separate maritime court from the time of Charles II (1660-85). It also dealt with pilotage; it was said to have been established as a court of load manage (or pilotage) in 1526 although it was, probably, operating earlier. Perhaps, prior to $1495 .^{528}$ Its last session as a court of pilotage was in 1851 ;

- Demise of Warden's Court. Save for admiralty matters, this court's jurisdiction was terminated by legislation in $1855 .^{529}$ It had its last sitting in 1872 and the place where the court sat was destroyed as a result of bombing in World War Two (1939-45). ${ }^{530}$ However, in respect of maritime matters (dealing with wrecks and prize), this court (qua the Cinque Ports' Court of Admiralty) still exists (with appeal to the Judicial Committee of the Privy Council). However, its last case was in 1914. ${ }^{531}$ A prior article has asserted that this court should be abolished. ${ }^{532}$

Did the Court of Shepway dispense justice according to the law merchant, in its existence from c. 1150 to c.1358? Did its successor (the Warden's Court) when it operated?

- It seems likely that the former, being a shire court, and the latter - being merged in effect with Chancery - would, generally, have dispensed the common custom of the realm (common law). So too, the local borough courts of the Cinque Ports - as well as of the Two Ancient Towns (the towns of Winchelsea and Rye) from $1200^{533}$ - although the position is unclear $;^{.54}$

- The only exception (one would suggest) is where there were specific local maritime customs (often, contained in local custumals) ${ }^{535}$ which provided otherwise and (one would suggest) there were few such customs prevailing.

\footnotetext{
${ }^{524}$ Ibid. Ballard I, n 51, p lxi 'As early as 1156 the court of the Cinque Ports was established at Shepway...'.

${ }^{525}$ As an appeal court, it only handled appeals on: (a) high treason; (b) falsifying money; (c) failure of ship service; (d) false judgment; (e) treasure trove. The Court of Shepway was falling in desuetude by the time Lambarde wrote in 1570, see W Lambarde, A Perambulation of Kent (Adams \& Dart, Bath, 1970 rep), p 165. See also McBain, n 50, p 112. A writ of error lay from this court to the King's Bench, Ibid, p 112 and Blackstone, n 186, vol 3, p 79. The Court of Shepway has never been formally abolished although it should be, since it has not sat as such for, likely, more than 400 years (possibly, since 1471), see S \& B Webb, The Manor and the Borough (Frank Cass \& Co, 1908, rep1963), vol 1, p 375, n 3. SPH Statham, Dover Charters and other Documents (JM Dent, 1902), pp 61- 69 contains an Inquisition of 14 April 1358 which suggests the Court of Shipway was held at the same time, and place, as the Warden's court.

${ }^{526}$ McBain, n 50, p 111. Also, Green, n 320, vol 2, p 392.

${ }^{527}$ For a plea as to the arrest of a ship before the Warden's court in 1358, see Statham, n 525, p 71 and pp 77-87 for pleas held at the church of St James at Dover.

${ }^{528}$ Webb, n 525, vol 1, p 376, n 1 'The regulations of the court of Lode manage date from 1495, and even then merely codified earlier custom.' See also Mears, n 520, p 315 (established in reign of Henry VIII (1509-47).

${ }^{529}$ Cinque Ports Act 1855 ( 18 \& 19 Vict c 48).

${ }^{530}$ McBain, n 50, p 112.

${ }^{531}$ See generally, Halsbury, Laws of England (4 ${ }^{\text {th }}$ ed), vol 1(1), para 532. Also, Holdsworth, n 26, vol 1, p 533.

${ }^{532}$ McBain, n 50, p 112. See also McBain, n 397, pp 50-1 (traces the history of the Cinque Ports' Court of Admiralty). See also Webb, n 525, vol 1, pp 374-6.

${ }^{533}$ Rye and Winchelsea were attached to Hastings as their head port prior to 1190 . However, from 1200, they were given the constitutional standing of head ports. See McBain, n 50, p 91.

${ }^{534}$ See McBain, n 50, pp 50-1.

${ }^{535}$ For example, Woodruff, n 457, p 230 referred to a $13^{\text {th }}$ custumal of the town which states a custom or, rather, a legal process: 'Of the Maritime Law. And it is to be known that when any neighbour or foreigner comes to the mayor and demands to have amends according to the maritime law, for the injury that some ship shall have done to another ship on the water, the mayor shall assign him two jurats [aldermen] who understand such law, and two masters of the vessels of the said town, who having heard the evidence of both parties shall award to each what he ought of right to have. And if the parties will not consent nor be willing to submit themselves to the judgment aforesaid, it is fit that they should plead either in the hundred court or in the court of the mayor at the option of the parties.' E Welch (ed), The Admiralty Court Book of Southampton 1566-1585 (Southampton UP, 1968), p xi quoted a Bristol admiralty court where admiralty causes were tried 'secundum leges et consuetudines ville, unde difficile sive impossible est singulos casus enumerare'.
} 
In conclusion, all Cinque ports maritime courts ended by 1835 with the demise of the Warden's court - save for the Admiralty Court of the Cinque Ports, which has been obsolete since 1914.

\section{(b) Local Admiralty Courts: Elsewhere}

As well as the Cinque Ports, in early times, there were local admiralty courts. ${ }^{536}$ Marsden stated:

From very early times there had been in existence in some of the seaport towns 'port' or 'marine' courts which, sitting from tide to tide and administering the law maritime to merchants and mariners, had some of the Admiralty Court of later times. ${ }^{537}$

Marsden cited 'port' courts in Ipswich, Yarmouth and Aldestowe (Padstowe). ${ }^{538}$ In respect of these local maritime courts, the best analysis is that of Welch.

- Welch noted that - in early times - borough courts of admiralty derived from those borough courts which had a port assuming jurisdiction. ${ }^{539}$ It is uncertain the number of these local courts of admiralty and where they existed. Welch listed 33 places; ${ }^{540}$

- Although contentious, ${ }^{541}$ an Ordinance of Edward I (1272-1307) may have given admirals a jurisdiction distinct from the local maritime courts in respect of certain legal matters; ${ }^{542}$

- There was also a close interconnection between the fair, market and quay in many places, such that the borough court likely handled all these matters. ${ }^{543}$

After the establishment of the HCA in c. 1340-57 (see (d)), there arose conflict between the jurisdiction of the HCA and the local maritime courts since the former began to hear cases of maritime debt, freight and ship ownership - matters formerly subject to the latter's jurisdiction. ${ }^{544}$

\footnotetext{
${ }^{536}$ The Municipal Corporations Act 1835, s 108 deprived all local courts of such admiralty jurisdiction they had (usually pursuant to a charter) excluding the Cinque Ports' Court of Admiralty. The Act provided 'so much of all laws statutes and usages, and so much of all royal or other charters, grants and letters patent heretofore granted to any borough or body corporate, whereby such borough, or any place within the precincts or liberties of the same...claims or claim to be exempted and released from the jurisdiction and office of the Lord High Admiral of England, or of the High Court of the Admiralty of England...shall be and the same is hereby repealed.' Cf. Halsbury (4 $4^{\text {th }}$ ed), n 531, vol 1(1), para 536, claimed that: (a) the Liverpool Court of Passage possessed admiralty jurisdiction until the Courts Act 1971, s 43, which abolished it; (b) the Mayor's and City of London court was an admiralty county court. Even if so, today, admiralty matters are administered by the High Court, the jurisdiction of the county court over admiralty matters being abolished in 1999, see Halsbury, n 531, para 482; McBain, n 379, p 50 and Carter, n 27, p 107.

${ }^{537}$ Marsden I, n 520, p xiii. Mitchell, n 30, p 40 stated that in 'England... the special local courts that had long existed in seaport and harbour were but the forerunners of the Admiralty, a national court with a general jurisdiction in maritime cases.' Also, $\mathrm{p} 72$. Senior, $\mathrm{n} 520$, p 19 thought that the local maritime courts were copies on a smaller scale of courts of the sea known to have existed in the mercantile cities of the Mediterranean at the beginning of the $12^{\text {th }}$ century.

${ }^{538}$ SS, vol 6, p xlix. See also Holdsworth, n 26, vol 1, p 531 and Mears, n 520, pp 329-30.

${ }^{539}$ Welch, $\mathrm{n} 535, \mathrm{p}$ xii 'In the Middle Ages boroughs were the most persistent seekers after privileges and they seem to have acquired a maritime jurisdiction very early. In every port where sufficient evidence has survived, these rights seem to have been associated with the grant of fee farm. The farming of royal revenues within the borough by the burgesses meant that they held the royal courts there. Since no distinction was then drawn between maritime and other jurisdiction each borough which was a port assumed a maritime jurisdiction. This was the origin of borough courts of admiralty.'

${ }^{540}$ For a list of 33 boroughs possessing, or claiming, some kind of admiralty jurisdiction, see Welch, n 535, p xxxiv. For Norwich, see also Green, $\mathrm{n} 320$, vol 1, p 245.

${ }^{541}$ It was contentious (especially with the common law courts' attempts to restrict the jurisdiction of the HCA) since it suggested that the heads of maritime matters (although not expressly called admirals but capitaneus maris and similar names) had jurisdiction prior to the supposed 'first' admiral in 1360, see n 551. See also Browne, n 520, vol 2, pp 24-5 and Pritchard, n 218, p 65 (Hale, Treatise on Admiralty c. 1676).

${ }^{542}$ Twiss, n 23, vol 1, p 69 'Item it was ordained at Hastings by [Edward I] and his lords, that though divers lords had several franchises to try pleas in ports, that neither their seneschals (or stewards) nor bailiffs should hold plea, if it concerns merchant or mariner as well for fact as charter of ships or (charter parties), obligations and other facts, tho' [unless] the same amounts but to twenty shillings or forty shillings.' Also 'Item any contract made between merchant and merchant, and merchant or mariner beyond the sea, or within the flood mark, shall be tried before the admiral and nowhere else by the ordinance of the said [Edward I] and his lords.' See also Hall, n 520, p xii. Scrutton, n $188, \mathrm{p} 172$ thought the Ordinance 'appears to furnish the origin of the admiral's jurisdiction in civil suits, which probably were more often settled informally by the merchants in the seaport towns 'selon la ley merchant."

${ }^{543}$ For example, as at Scarborough in 1376, when fair, market and quay were all in the same place. See Senior, n 520, pp 18-9 \& 21.

${ }^{544}$ See generally, introductions in Welch, n 535; Marsden I, n 520 and Pritchard, n 218.
} 
- The winner was the HCA since - although various towns were exempted from the jurisdiction of the HCA ${ }^{545}$ - there was a tailing off in exemptions by the end of the $15^{\text {th }}$ century, ${ }^{546}$ by which time Kiralfy maintained that the HCA had 'replaced practically all these jurisdictions'; ${ }^{547}$

- Those that may have survived had their jurisdiction effectively negated by Holland's Case (1451) where it was held that all ports and havens in England were infra corpus comitatus and that the HCA, therefore, could not hold jurisdiction of any thing done in them, which Coke CJ confirmed in Greenway \& Barker's Case (1612). ${ }^{548}$

\section{In conclusion, all local maritime courts were abolished by the Municipal Corporations Act 1835. \\ (c) Courts of Vice-Admirals of the Coast}

Technically, these still exist (they are distinct from colonial Vice-Admirals' courts). ${ }^{549}$ However, these courts seem to have become obsolete by the early $19^{\text {th }}$ century. ${ }^{550}$ In respect of them:

- Vice-Admirals of the Coast. Vice-Admirals of the Coast were appointed by patent, to represent the Lord High Admiral ('LHA'). Since the latter post only arose from $1360,{ }^{551}$ this would be the earliest date from which they could have been created. ${ }^{552}$

- These should not be confused with certain Under (Vice) Admirals of the West, North and South who seem to have been created from $1337-8 .{ }^{553}$ The latter (and their courts) likely dis-appeared after Vice-Admirals of the Coast were appointed by the LHA. ${ }^{54}$ The last admirals of the North and of the West cited by Alexander Justice (in a list he compiled) were in $1406,{ }^{555}$

- Vice-Admiralty Courts. In respect of these, the sea coast of England was divided into 19 districts, for which of each a Vice-Admiral of the Coast might be appointed. Such persons represented the LHA or

\footnotetext{
${ }^{545}$ Marsden I, n 520, p xiii-iv 'it appears to have been the practice for the sovereign to exempt certain of the seaport towns from the jurisdiction of the admiral. In some cases the charter contains an express grant of Admiralty jurisdiction. There is mention in the Admiralty Court records of such records having been made to Yarmouth, Dartmouth, Rochester and other towns...In some of the statutes referring to the admiral's jurisdiction there is an express saving of the rights of seaport towns.' Welch, $\mathrm{n} 535$, pp xiv-v asserted that the first town to get exemption was Kingston-Upon-Hull in 1382, with York in 1442, Newcastle-upon-Tyne in 1444 and Southampton in 1445. MacDonell, n 375, p lxxvii 'In the treaties between England and the Hanseatic towns it was specially stipulated that no sailor or merchant of the Hanse should be expected to endure Admiralty jurisdiction.'

${ }^{546}$ Welch, n 535, pp xv-vi.

${ }^{547}$ Kiralfy, n 208, p 106 'There were complaints in Parliament in the fourteenth century against the encroachments of these courts on the jurisdictions of borough and manor, but during the fifteenth century a united [HCA] replaced practically all these jurisdictions.'

${ }^{548}$ See Godb 260 (78 ER 151). The Earl of Exeter held a plea of the admiralty of a matter done at the port of Hull. Damages of $£ 2,000$ were recovered against him.

${ }^{549}$ Halsbury, n 531, vol 1(1), para 480 'The sea coast of England and Wales is divided into 19 districts, for each of which a Vice-Admiral of the coast may be appointed. Vice-admirals of the coast represent the Lord High Admiral, or the Lords Commissioners for executing that office, in his capacity so far as it is not concerned with the navy. They were appointed by letters patent under the Great Seal...The jurisdiction extends up to the high water mark and to the first bridges towards the sea on rivers, and is exercisable by a judge. The patent of the Vice-Admiral empowers him to appoint his own officers, excepting, however, the judge, registrar and marshal of the Vice-admiralty court. These excepted officers are appointed by letters patent, but there are none in existence at the present time, and, consequently, although the jurisdiction of these courts of Vice-Admiralty over causes of action arising in the jurisdiction has never been abolished by statute, there is now no means of executing it. There is no jurisdiction as to wreck.'

${ }^{550}$ Ibid.

${ }^{551}$ Marsden I, n 520, p xliii 'The title of 'High Admiral'...can scarcely have been used before the appointment of Sir John Beauchamp to the command of all fleets in 1360 .'

${ }^{552}$ See generally, S Baker, The Office of Vice-Admiral of the Coast (privately printed, 1884). Spelman, n 520, vol 2, p 224 'The vice or deputy admiral...seems to have had his beginning suddenly after the election of the high admiral...'

${ }_{553}$ Twiss, n 23, vol 1, pp xxx- ii \& pp 17-9. Cf. Browne, n 520, vol 2, p 25-6 who thought these existed from the reign of Edward I (1272-1307).

${ }^{554}$ Marsden I, n 520, p lii 'It is not known when the courts of the Admirals of the North, South, and West ceased to exist. Probably, they fell into disuse in consequence of the irregularities...committed by the deputy of the Admiral of the West.' The reference was to John Holland, the Earl of Huntingdon (half-brother of Richard II (1377-99)) who had given occasion for a petition to Parliament 'on account of his alleged extortion and the undue extension of his jurisdiction'. See also Twiss, n 23, vol 1, p xxxviii; Marsden II, n 520, vol 1, p xiii and Mears, n 520 p 313.

${ }_{555}$ Alexander Justice, General Treatise of the Dominion of the Sea $\left(1^{\text {st }} \mathrm{ed}, 1705\right), \mathrm{p} 287$. John Beaufort, Earl of Somerset was appointed admiral of the Northern and Western fleets in 1406. See also Twiss, n 23, vol 1, p xxxv and Senior, n 520, p 17. Kiralfy, n 208, p 107 thought that the LHA superceded these admirals of the North, South and West.
} 
the Lords Commissioners ${ }^{556}$ and they applied civil law. ${ }^{557}$ Welch thought that such courts were first created post-1540. Possibly, from $1565{ }^{558}$

- Desuetude. The appointment of Vice-Admirals fell into desuetude. ${ }^{559}$ Indeed, it seems likely that most appointments ended by the late $18^{\text {th }}$ century - although, as a sinecure, they continued into the $20^{\text {th }}$ century. ${ }^{560}$ Their courts, however, were superceded much earlier, probably, prior to $1835 .^{561}$

Vice-Admirals of the Coast - and their courts - are long obsolete, not likely having sat since 1835, at least. Further, it no longer seems possible to create them. They should be abolished. ${ }^{562}$

\section{(d) High Court of Admiralty ('HCA')}

Marsden thought the earliest evidence of the use of the title 'admiral' in England was in 1300 when Gervase Alard was called admiral of the fleet of the Cinque Ports ${ }^{563}$ and that:

For more than half a century after the first occurrence of the title 'admiral', no mention is to be found... of the existence of an Admiral's court having power to hear pleas and to administer [maritime] justice between parties. ${ }^{564}$

The HCA seems to have been established in the period $1340-57,{ }^{565}$ being formed to deal with cases of piracy 566 and headed by an admiral.

- Prior to this date, Marsden considered that jurisdiction in respect of piracy claims - and the ownership of goods taken at sea - was in various hands, viz. those of the: Chancellor (the Chancery), the King's Council, the King's Bench or commissions of oyer and terminer; ${ }^{567}$

- Further, it seems that admiralty claims in this period were heard by these bodies according to the common law and the law merchant ('secundum legem et consuetudinem dicti regni et similiter legem mercatoriam absque dilatione morosa'), although, in other cases, the common law alone was applied. ${ }^{568}$ Also, references to the law merchant were used together - or interchangeably with - references to maritime law (legem maritimam). ${ }^{569}$ This is unsurprising since, in those times, civilian ships were few

\footnotetext{
556 The LHA was in abeyance from 1709 and merged into the Crown (it was re-created for Prince Philip as a sinecure on his $90^{\text {th }}$ birthday) and his powers were exercised by the Lords Commissioners of the Admiralty who possessed the same jurisdiction, see $2 \mathrm{~W} \& \mathrm{M}$ sess 2 c 2 (1690, rep 1964). The style of the judge of the High Court of Admiralty was lieutenant of the High Court of Admiralty of England. See also Hall, n 520, p 4. For the LHA and abolition of his office, see McBain, n 289, p 54.

557 See Halsbury, n 531, vol 1(1), para 489. Also, McBain, n 397, pp 51-2.

${ }^{558}$ Welch, n 535 p xvii. JS Purvis, The Records of the Admiralty Court of York (St Anthony's Press, York, 1962) refers to records from 1601-1745, which suggest that a Vice-Admiral's Court in York was operating during this time with the Archbishop of York acting as Vice-Admiral. Prior to any Vice-Admiral's court at York, there may have been a borough court at York dealing with admiralty matters. Welch, p xxxiv refers to a charter of 1442 .

${ }_{559}$ Baker, n 552, p 2 stated that the office of Vice-Admiral had fallen into desuetude 'within the last hundred years.' J Montefiore, A Commercial Dictionary (1803) (admiralty) mentioned colonial Vice-Admiralty courts but not local ones, which suggests they had disappeared by his time. Browne (in 1802), n 520, vol 2, ch 12 discussed no domestic vice-admiralty courts, only colonial ones.

${ }^{560} \mathrm{Ibid}, \mathrm{pp} \mathrm{75-5}$, the conflict between the rights of Vice-Admirals and legislation and that there were only 3 Vice Admirals in office for England and Wales in 1863. RG Marsden, The Vice-Admirals of the Coast (1908) English Historical Review, vol 23, pp $736-57$ wrote that the office was a 'titular dignity' (i.e. a sinecure).

${ }^{561}$ Welch, n 535, pp xxi-ii. Roscoe, n 520, p 18 'the jurisdiction which at one time existed in these tribunals being absorbed by the [HCA].'

${ }^{562}$ See McBain, n 397, pp 51-2.

${ }^{563}$ Marsden I, n 520, p xii. Also, 'It would appear...the title of admiral, originating probably in the East and afterwards adopted by the Genoese and other navies of the Mediterranean, came by way of Gascony to England, and was there adopted about the beginning of the fourteenth century.' See also Carter, n 27, p 102 and Holdsworth, n 26, vol 1, pp 544 et seq.

${ }^{564}$ Ibid, p xiii. Mitchell, n 30, p 74 'Gervase Abelard is mentioned as admiral of the fleet of the Cinque ports, but for half a century there is no evidence that an admiral's court existed with judicial powers over non-members of the fleet.' See also Shilton, n 520, p xvi.

${ }^{565}$ For the latter date, see Marsden I, n 520, p xli. Also, Kiralfy, n 208, p 107 and Carter, n 27, p 102.

${ }^{566}$ Marsden I, n 520, pp xiv-v.

${ }^{567}$ Ibid, pp xiv-v. Kiralfy, n 208, p 107 'It is thought that the civil jurisdiction of the [HCA] was largely acquired in the same manner as that of the Chancery, namely, that petitions to the Council were delegated to the Admiral or his deputy.'

${ }^{568}$ Ibid, p xix. See e.g., p xxxix, a Yearbook case of 1348, 22 Edw III fo 16, pl 63, Seipp no 1348.173 (property in goods re-captured at sea from an enemy came before the common law courts and the case was decided according to the 'commun loy'.) See also Carter, n 27, pp 103-4.

${ }^{569}$ Marsden I, n 520, pp xlii-iii.
} 
and small and many merchants would also have been mariners, undertaking both roles. Also, the jury in the local admiralty courts was, often, a mixture of mariners and merchants. ${ }^{570}$

As well as the HCA coming into conflict with local maritime courts (see (b)) ${ }^{571}$ it was also hearing cases of wreck by $1377{ }^{572}$ - a common law matter. It was almost inevitable, therefore, that there would be a 'turf' war between the HCA and the common law courts (as well as the local maritime courts) and this occurred early likely, within 50 years (or less) of the existence of the HCA. As a result of such conflict, two statutory attempts were made to limit the jurisdiction of the HCA: ${ }^{573}$

- Act of 1390. ${ }^{574}$ It provided: 'Forasmuch as a great and common clamour and complaint has been oftentimes made before this time, and yet is, for that the admirals and their deputies hold their sessions within divers places of this realm as well within franchise as without, accroaching to them greater authority than belongs to their office, in prejudice of our lord the king, and the common law of the realm, and in diminishing of divers franchises, and in destruction and impoverishing of the common people: it is accorded and assented that the admirals and their deputies shall not meddle from henceforth of any thing done within the realm, but only of a thing done upon the sea, as it has been used in the time of [Edward III, 1327-77]';

- $\quad$ Act of 1392. ${ }^{575}$ It provided: 'It is declared, ordained and established, that of all manner of contracts, pleas, and quarrels, and all other things rising within the bodies of the counties, as well by land as by water, and also of wreck of the sea, the admiral's court shall have no manner of cognizance, power, nor jurisdiction; but all such manner of contracts, pleas, and quarrels, and all other things rising within the bodies of counties, as well by land as by water, as afore, and also wreck of the sea, shall be tried, determined, discussed and remedied by the law of the land, and not before nor by the admiral, nor his lieutenant in any wise...'. 576

Despite these Acts, the HCA was intent on augmenting its jurisdiction ${ }^{577}$ and an Act in 1540 gave it jurisdiction to deal summarily with cases of freight, damage to cargo and charterparties. ${ }^{578}$ By the $16^{\text {th }}$ century, Marsden noted that the HCA was hearing - besides cases of spoil, piracy, wreck and contempt ${ }^{579}$ - mercantile, shipping and commercial matters. He stated:

\footnotetext{
${ }^{570}$ See, e.g., Marsden, n 520, p xlix who referred to Hamely v Alveston (1383)( application made to the King's Bench upon scire facias to obtain execution of a judgment obtained in a curia marina (maritime court) held at Aldestowe (Padstow) in an action for trespass to a ship in Plymouth sound). See also Pritchard, $\mathrm{n} 218$, $\mathrm{p}$ xxxi 'secundum usum et consuetudinem ville predicte et secundum legem maritimam.'

${ }^{571}$ Ibid, p xiii. In 1371, there was a complaint in Parliament that the people were vexed by a novel procedure, which may refer to the HCA. Ibid, pp xliv and xlvii (for the petition). See also Thornely, n 30, p 19. Shilton, n 520, p xvi 'The attempts of the [HCA] to assume general maritime jurisdiction aroused the jealousy and opposition of the local franchisal seaport towns, of the common law courts, and of Parliament itself.'

${ }^{572}$ Ibid. See also Carter, n 27, p 103 (mentions a case in 1353 re ownership of goods) and p 157 (re prize).

${ }^{573}$ They may have been a result of the behaviour of John Holland, Admiral of the West, see, n 554. Kiralfy, n 208, pp 107-8 'In the reign of Richard II [1189-99] the admiral was exercising a wide jurisdiction in civil matters, but it seems that the Council was considered to be the proper tribunal to hear petitions and that for convenience they were referred to him by way of special case. At this time there were a number of petitions against the exercise of judicial functions by the Council and it may well be that the close association of the [HCA] with the Council was one of the causes of the outcry against the Admiralty jurisdiction in his reign.' See also Senior, n 520, p 26.

57413 Ric 2 st 1 c 5 (rep 1881). See also Holdsworth, n 26, vol 1, p 548.

57515 Ric 2 st 2 c 3 (rep 1879, 1967). Kiralfy, n 208, p 108 'These statutes [of 1389 and 1391] did not apply to matters arising on land beyond the seas; it is probable that the Council would have heard petitions concerning such disputes and that delegation to the admiral then took place in the fifteenth century.' See also Holdsworth, n 26, vol 1, p 548.

${ }^{576}$ Marsden, $\mathrm{n} 520 \mathrm{p}$ li 'The statutes of Ric II do not appear to have prevented the evils which they were intended to meet, and in 1400 another Act [2 Hen IV c 11, rep 1861] was passed by which a penalty was imposed upon those who sued in the [HCA] contrary to the statutes of Richard II.'

${ }^{577}$ Kiralfy, n 208, pp 108-9. Carter, n 27, p 104 notes the first patent appointing a judge of the HCA was in 1482. See also Holdsworth, n 26, vol 1 , pp 545 et seq.

578 Ibid, p 109. Marsden I, n 520, p lvii 'The [Act of 1540, 32 Hen VIII c 14], giving the admiral jurisdiction to try summarily matters of freight and damage to cargo, appears to have been passed with a view to attract business to the [HCA]. That some important change must have taken place in the working of the court about this period is evident from the very great increase in the business transacted during the first ten or twenty years after the commencement of the records [of the HCA].'

${ }^{579}$ Marsden I, n 520, p lxviii noted these were proceedings by the HCA (as it fought for supremacy) against local courts such as the bailiffs of Yarmouth, Dartmouth and Southampton.
} 
How and when it [the HCA] acquired a jurisdiction in maritime cases generally, is not so clear, ${ }^{580}$ but there is evidence that from the end of the fourteenth century it was exercising such a jurisdiction...

It was, probably, the rapid increase of business in the [HCA] connected generally with shipping and foreign trade that first aroused the professional jealousy of the practitioners of the common law. All contracts made abroad, bills of exchange...commercial agencies abroad, charter-parties, insurance, average, freight, non-delivery of, or damage to, cargo, negligent navigation by masters, mariners, or pilots, breach of warranty of seaworthiness, and other provisions contained in charterparties; in short, every kind of shipping business was dealt with by the [HCA]. The law merchant, which was there administered, particularly with reference to bills of exchange, bills of lading, and charter-parties, appears to have been recognized in the [HCA] earlier and far more fully than it was in the courts of common law. ${ }^{581}$

Marsden mentioned the 'professional jealousy of the practitioners of the common law' and this friction became acute in the late $16^{\text {th }}$ century, ${ }^{582}$ especially when Coke became Chief Justice $(1606-13){ }^{583}$ The loser was the $\mathrm{HCA}^{584}$ which only began to, later, revive due to a great increase in its prize jurisdiction. ${ }^{585}$ The Admiralty Court Act 1840 and its successors gave the HCA an, almost complete, jurisdiction over shipping matters. ${ }^{586}$ Finally, the HCA became a division of the High Court in $1875 .{ }^{587}$ As for the HCA's jurisdiction over matters relating to the law merchant:

- To the extent the same comprised local maritime customs, it is asserted that many of these customs would have disappeared after Holland's Case (1451) (see (b)) since the HCA, then, had no jurisdiction over ports and havens in England;

- This, together with the decline at the same time of local maritime courts, (since they were superceded by the HCA) would have meant that common law courts (borough courts) would have dealt with such

\footnotetext{
${ }^{580}$ Ibid, p lx. Marsden stated that the records of the [HCA] began in 1524 and continued until the court was merged in the High Court of Justice, pursuant to the Judicature Act 1875. Cf. AA Ruddock, The Earliest Records of the High Court of Admiralty. BIHR vol 22 (1949), 139, 151. See also Pritchard, n 218, p xix.

${ }^{581}$ Ibid, pp lxvii-iii. Also, 'Owners of ships and goods wrecked upon the shores of England resorted to the [HCA] to obtain possession of their property. Spoil or pillaging wrecks was of common occurrence, and commissions frequently issued from the [HCA] directing the persons named in the commission to search for, and take possession of, wrecked goods which had come into the hands of persons other than their owners...The statutes of Richard II [see ns 574 \& 575] providing that wreck should be tried by the common law appear to have been disregarded, and no prohibitions occur upon this matter.' Thornely, n 32, p 25 'In 1548 the admiralty court tried a case of insurance, and in 1593 the first mention is made of bottomry.'

${ }^{582}$ For the history see Pritchard, n 218, introduction. Kiralfy, n 208, p 109 'During the reign of Elizabeth I the attack upon the court by the common law judges began in earnest, though at first the ground for their interference in a case was merely that the cause of action in question arose within the body of a county. In spite of this moderation, prohibitions pressed so heavily upon the [HCA] that certain articles of agreement were drawn up in 1575, which allowed the [HCA] a jurisdiction over contracts arising beyond the sea and charter parties to be performed on or beyond the sea, although made 'at land.' For the Articuli Admiralitatus (Remonstrance of the Court of Admiralty to King James I) by the HCA complaining about the violation of the Articles of 1575, see Coke, n 16, vol 4, ch 22. MacDonell, n 375, p lxxvii 'By Lord Hobart's decision in Bridgeman's Case [Hob 11, 80 ER 162] the cognizance of contracts made at sea, but not for or in respect of maritime matters, was withdrawn from the [HCA]. By fictitious allegations that contracts really made at sea were made at the Royal exchange, actions on charter-parties were brought within the purview of the courts of common law.' See also Carter, n 27, pp 106-7; Holdsworth, n 26, vol 1, pp 553-9; Coquillette, n 13, p 106 et seq. and Pritchard, n 218, pp 55-6.

${ }^{583}$ For a useful summary see Kiralfy, n 208, p 110 who also noted: 'In the eighteenth century hypothecation of the ship, or what is now called a 'bottomry bond', was admittedly within the [HCA] jurisdiction though made 'at land.' The court also had jurisdiction over forfeitures of ships and cargo for the numerous offences against the customs laws which were committed at that time. By the encroachments of the common law courts, however, there was nothing left of its jurisdiction over contracts made beyond the seas, charter parties or marine insurance.'

${ }^{584}$ An unsuccessful defence of the HCA, and of maritime law being ius gentium, may be found in texts such as: (a) J Exton, The Maritime Dicaeologie or Sea Jurisdiction of England (1 $1^{\text {st }}$ ed,1664, last ed, 1755); (b) Zouch, n 19; (c) Godolphin, n 7; (d) L Jenkins, Argument on the Statute of 13 R II [1390] concerning the Jurisdiction of the Admiralty before the House of Lords, in answer to Lord Chief Justice Vaughan (contained in Wynne, Life of Sir Leoline Jenkins (printed for J Downing et al, 1724)). For Coke on the HCA, see n 16, vol 4, ch 22. For the struggle between common and civilian lawyers see BP Levack, The Civil Lawyers in England 1603-1641 (Oxford, Clarendon Press, 1973).

585 See generally, GS McBain, Modernising the Law of Prize (2014), issue 6, pp 465-83.

${ }^{586}$ See Kiralfy, n 208, p 111 and Carter, n 27, p 107.

${ }^{587}$ Roscoe, n 520, p 4 'its [the HCA's] jurisdiction was, in 1873, by the Judicature Act of that year, transferred to the newly created Supreme Court of Judicature and conferred on one division of that tribunal, the Probate, Divorce and Admiralty. The Judicature Acts of 1873 and of 1875 did not, however, come into operation until November 2, 1875, and on that day the [HCA] nominally ceased to function.'
} 
matters and (likely) they would have had little interest in upholding local medieval maritime customs of increasing irrelevance and of little benefit to the community. ${ }^{588}$

Prior to concluding on the extent early English maritime law comprised part of the law merchant, something needs to be said of the reception by the HCA - and, prior to it - local maritime (and Vice- Admiralty courts), of foreign laws (and foreign commentary thereon).

\section{(e) Laws of Oleron ${ }^{589}$}

When applying maritime law/law merchant, ${ }^{590}$ the HCA (and local maritime courts) referred to foreign maritime laws. However, despite later claims that such laws were part of a 'ius gentium' (see 19) there seems to be no evidence that the HCA (also, the common law courts) ever applied such foreign law directly. It was of persuasive value only. ${ }^{591}$

- The exception were certain Laws (also called rules, rolls, judgments or customs) of Oleron, which may have been enacted as part of English law. Confusion has arisen in respect of these Laws of Oleron since both their origin, and their relationship to English law, has been a matter of dispute;

- Many English legal writers - including Coke and Selden - asserted that the Laws of Oleron were part of English law as a result of legislation made by Richard I (1189-99). Later writers, aware that there was no definite authority for this, also asserted that - in any case - the Laws of Oleron became part of the common law by way of received mercantile custom.

Both such assertions were reflected in statements made by Sir Leoline Jenkins, a judge of the HCA, ${ }^{592}$ who, in 1688, declared:

The laws of Oleron, are the ancient universally received customs of the western part of the world, which Richard I [1189-99] ... upon his return from the holy war, thought fit to review and reform, and then to give them the stamp of his royal authority. ${ }^{593}$

Also:

I call these the laws of Oleron, not but that they are peculiarly enough English, being long since incorporated into the customs and statutes of our admiralties; but the equity of them is so great, and the use and reason of them so general, that they are known and received all the world by them rather than by any other name. ${ }^{594}$

The issue, therefore, is - Did Richard I enact into English law the Laws of Oleron or did someone else? If the latter, the best candidates are that they were enacted by Eleanor (his mother) or by Edward I (1272-1307). As to this:

- $\underline{\text { Richard I. Coke }}{ }^{595}$ (as well as Selden, ${ }^{596}$ Blackstone ${ }^{597}$ and others) ${ }^{598}$ thought the Laws of Oleron were a compilation made by Richard on his return from the Holy Land, after crusading, when he

\footnotetext{
${ }^{588}$ In the case of the Cinque Ports, their heyday was until the $14^{\text {th }}$ century. After that, they went into considerable decline. See McBain, $\mathrm{n} 50$. For other ports in England, the assertion of local maritime customs to benefit themselves would also have experienced considerable decline. A list of English ports and havens (relatively few) by 1752 is contained in Beawes, n 21, pp 123-4.

${ }^{589}$ For a modern analysis of the Laws of Oleron (which supercedes much prior writing), see Piergiovanni I, n 41, pp 206-53, chapter by JW Shephard, The Roles d'Oleron: A Lex Mercatoria of the Sea? See also TJ Runyan, The Rolls of Oleron and the Admiralty Court in Fourteenth Century England (1975) 19 Am J of Legal History 95.

${ }^{590}$ In early times, because most mariners were also merchants (carrying goods and people), there was no need to make a distinction between them.

${ }^{591}$ This point was to be re-emphasised by C Abbott, A Treatise on the Law relative to Merchant Ships and Seamen $\left(1^{\text {st }}\right.$ ed, 1802), $\mathrm{p}$ vii, see $\mathrm{n}$ 952 as well as, in later Victorian times, by Esher MR, see n 685.

${ }_{592}$ Jenkins (1623-85) was a judge of the HCA, from 1665. See Coquillette, n 13, pp 189-97 for commentary on him.

${ }^{593}$ Charge given at a sessions of Admiralty within the Cinque Ports in 1668, see Wynne, n 584, vol 1, p lxxxvii. See also a Charge at an Admiralty sessions at the Old Bailey, Ibid, p xci 'the laws of Oleron, which king Richard I gave his royal stamp to in that island, part of the inheritance of his Queen, a countess of Guienne...'. Since Richard's queen was Berengaria of Navarre (c.1165/70-1230) this was inaccurate. Rather, it was the inheritance of his mother, Eleanor of Aquitaine.

594 Ibid.

${ }^{595}$ Coke, n 16, vol 1, 159(b)(meaning of an ordinance) \& vol 4, p 144 'Quae quidem leges et statuta per dominim Richardum quondam regem Angliae in reditu suo a terra sancta correcta fuerunt, interpretata et in insula Oleron publicata et nominata in Gallica lingua La Ley Olyronn.' [which laws and statute by Lord Richard on his return to England from the Holy Land, were corrected, interpreted and published in the island of Oleron in the Gallic language [as] the Law of Oleron].

${ }^{596}$ J Selden, The Dissertation of John Selden annexed to Fleta (London, trans, 1771), p 241 'Richard the first (who was...looked upon as the author of the Oleronian)...' J Selden Mare Clausam, Of the Dominion of the Sea (published in latin in 1635, see English trans by M Nedham
} 
stopped at the Isle of Oleron - an island in the Bay of Biscay, off the coast of France. ${ }^{599}$ This cannot be correct since Richard never visited Oleron on his return from the Holy Land (nor, indeed, when he went to the Holy Land). ${ }^{600}$

- Ordinance on Martial Law 1190. Confusion may be due to the fact that Richard issued an Ordinance in 1190 (new calendar, 1189, old calendar) which applied to those going by sea to the Holy Land on crusade. It imposed martial law on military and naval personnel ${ }^{601}$ and it was later said to be part of the laws of Oleron. However, there is no basis for this since its terms are quite different; ${ }^{602}$

○ Chancery Roll of 1339. Coke (and Selden) may have made their mistake by referring to a Chancery roll of 1339 containing a 'Fasciculus de Superioritate Maris'. ${ }^{603}$ As Scrutton noted, this document recited that the justiciaries of the king were to be consulted as to the proper mode of revising and continuing the form of proceeding instituted by Edward I (1272-1307) and his Council for the purpose of :

'maintaining the ancient supremacy of the Crown over the sea of England, and the right of the admiral's office over it, with a view to correct, interpret, declare, and uphold the laws and statutes made by the kings of England, his ancestors, in order to maintain peace and justice amongst the people of every nation passing through the sea of England, and to punish delinquents, 'which laws and statutes were by [Richard I] on his return from the Holy Land, corrected, interpreted and declared and were

(London, 1652), p 386 'Richard [I], being in the isle of Oleron, which he possessed as seated in his own sea, not so much for that he was Duke of Aquitaine as king of England ...did, as sole ruler and moderator of sea affairs, first publish those naval or sea laws in that his island, which hold in force to this day, and from that time gave them so large and perpetual an authority by that name...so the laws of Oleron having obtained a kind of authority by sea, from their first institution, must ever declare the king of England as the author, to be lord of the neighbouring sea around him.'

${ }^{597}$ Blackstone, n 186, vol 4, p 416 'Richard...when abroad, composed a body of naval laws at the isle of Oleron; which are still extant, and of high authority...' Ibid, vol 1, p 405 'To so much perfection was our naval reputation arrived in the twelfth century, that the code of maritime laws, which were called the laws of Oleron, and are received by all nations in Europe as the ground and substruction of all their marine constitutions, was confessedly compiled by our king Richard the first, at the isle of Oleron on the coast of France, then part of the possessions of the crown of England'. He cited Coke (see n 595).

${ }^{598}$ Zouch n 19 (see Malynes, $3^{\text {rd }}$ ed, 1686, n 22, vol 1, pp 89-90 which contains his text) followed Coke and Selden. Molloy, n 20 ( $9^{\text {th }}$ ed, 1769 ), vol 1, p 386 stated that Richard I made the laws 'at Oleron...(then part of his dominions, as sovereign lord of the ocean, and all those maritime kingdoms).' A Duck, De Usu et Authoritate Juris Civilis (1653, text appended to CJ de Ferriere, The History of the Roman or Civil Law (1724)), p xxxv 'the laws of Oleron, made by Richard I, who was in possession of that island, are in use.'

599 Later legal writers were more equivocal. Kiralfy, n 208, p 103 'The laws of Oleron predominated in the west. This ....code, traditionally associated with the commune of Oleron on the Bay of Biscay, was adopted by the seaports of Normandy and Brittany and was later transplanted to England.' Thornley, n 32, p 8 'The judgments of Oleron... have been described as part of English law, the tradition being that Richard I [1189-99] brought them from Palestine; whether or not this legend be true, it is certain that the judgments of Oleron had universal application, and were regarded, at least, by the merchants as being of the utmost value.' Holdsworth, n 26, vol 1, p 527 the laws of Oleron 'originated in the laws of the commune of Oleron; they were adopted by the seaport towns of Normandy and Brittany; and they were transplanted' to ... England.' (italics supplied).

${ }^{600}$ Noted by Twiss, n 23, vol 2, p xlviii. Also, vol 1, p lviii (more likely, on his return from England). Pritchard, n 218, pp xxxiii \& 62, (Hale, Treatise on Admiralty c. 1676), Hale thought this tradition was 'altogether incredible' and 'utterly improbable' although Hale also noted, $\mathrm{p} 59$ 'the laws of Oleron are of greatest esteem and authority, at least among us in England.' See also Ibid, p 67.

${ }^{601}$ Pritchard, n 218, p 61 (M Hale, Treatise on Admiralty, c. 1676) 'no affinity with the laws of Oleron'. For the text of the Ordinance, E Samuel, An Historical Account of the British Army (London, 1816), p 60 'Made at Chinon, $1^{\text {st }}$ Richard, 1189. Charter of king Richard, for the government of those going by sea to the Holy Land. 'Richard, by the grace of God, king of England, Duke of Normandy etc. To all his men going by sea to Jerusalem, greeting, Know ye, by the common council of all good men, we have made the underwritten ordinances, He, who kills a man on ship-board, shall be bound to the dead man, and thrown into the sea; if a man is killed on shore, the slayer shall be bound to the dead body and buried with it. Anyone convicted by lawful witnesses of having drawn his knife to strike another, or who shall have drawn blood of him, to lose his hand. If he shall have only struck with the palm of his hand without drawing blood, he shall be thrice ducked in the sea. Anyone who shall reproach, abuse, or curse his companion, shall, for every time he is convicted thereof, give him so many ounces of silver. Anyone convicted of theft, shall be shorn like a champion, boiling pitch shall be poured on his head, and down of feathers shaken over it, that he may be known, and he shall be set on shore at the first land at which the ship touches.' Samuel noted 'Champions hired to fight legal duels, in cases of murder and homicide, had their hair clipped close to their heads.' See $R v$ Brand and Nelson (1867) Charge of the Lord Chief Justice of England to the Grand Jury at the Central Criminal Court in the case of the Queen against Nelson and Brand (London, Ridgway); W McFee, Law of the Sea (1951), p 63 and AL Poole, Domesday Book to Magna Carta (Oxford History of England, $2^{\text {nd }}$ ed, 1955), p 438.

${ }^{602}$ There is also an Ordinance of Richard I made at Grimsby (Grymsby), possibly, in 1194 in respect of impressing ships and men for the king's service, see Twiss, $n$ 23, vol 1, p xlvii \& 65-7. This, also, had nothing to do with the Laws of Oleron.

${ }^{603}$ Marsden I, n 520, p xxxii. See also Holdsworth, n 26, vol 1, pp 544-5 and Shephard, n 589, p 218. 
published in the island of Oleron, and were named in the French tongue 'la ley Olyroun.' 604

It is also possible that - on Richard I's return from the Holy Land to England on 20 March 1194 and prior to his departure for Normandy on 12 May 1994 (he never returned, dying in 1199) - he promulgated the Laws of Oleron. ${ }^{605}$

- Queen Eleanor. The Laws of Oleron may, alternatively, have been promulgated by Eleanor the mother of Richard I. ${ }^{606}$ As to when:

(a) Journey to Holy Land: 1148-9. (a) Eleanor of Aquitaine (1122/4-1204) became Duchess of Aquitaine in 1137. The same year she married Louis VII of France (1137-80) with whom she went to the Holy Land in 1148-9.

- A possibility, therefore, is that - on her return - she took back with her to Aquitaine certain Assizes (laws) of the kingdom of Jerusalem (see below). Oleron was the seat of the special court of the duchy of Guyenne and, as duchess of Guyenne, Eleanor may have ordered the court to incorporate these Assizes in respect of maritime matters; ${ }^{607}$

- However, this still does not explain how the Laws of Oleron became part of English law (if at all). Further, the maritime provisions in the Assizes of Jerusalem (see below) cannot account, per se, for the Laws of Oleron, since they are fewer articles in number;

(b) Vice-Regent of England: 1190-9. (b) Eleanor's marriage to Louis VII of France was annulled in 1152. That year she became the wife of the (later) king Henry II (1154-89), the father of Richard I (1189-99). When Richard was absent from England, his mother was granted vice-regal power to act in his stead. Thus, she may have promulgated previously existing Laws of Oleron, in England, using her vice-regal power, sometime, in the period $1190-9 ;^{608}$

(c) Assizes of Jerusalem not same as Laws of Oleron. The difficulty with (a), is that the Assizes of Jerusalem are not the same as the Laws of Oleron.

- $\quad$ These assizes (laws) of the Court of Burgesses (Livre des Assizes de la Cour des Bourgeois) of the kingdom of Jerusalem were compiled in French in the 1250's. ${ }^{609}$ However, they reflected the laws at an earlier date since the kingdom of Jerusalem was established in 1099 as a result of the First Crusade (it, effectively, ended by 1291 when the kingdom was re-taken by the Moslems); ${ }^{610}$

- Twiss and Coureas cited a version of the Assizes from the time of Almaric I, since there seems to be no earlier version extant. Almaric I was king of Jerusalem from 1163-74. He was said to be skilled in customary law ${ }^{611}$ and to have instituted a

\footnotetext{
${ }^{604}$ Scrutton, n 188, p 171. See also Twiss, n 23, vol 1, p lvii.

${ }^{605}$ Twiss, n 23, vol 2, p lii mentioned this possibility, that 'the Rolls were compiled in Oleron by order of king Richard I, and that they were reviewed and sanctioned by royal authority after his return to England from the fourth Crusade.' This is based on Richard I, much earlier in his life, as Duke of Aquitaine, compiling them in Oleron. (italics supplied). See also Exton (1755 ed), n 584, pp 24-5 '[Richard I] brought those laws of Oleron hither with him [from Oleron to England], and here settled and declared them for laws.'

${ }^{606}$ This was a theory promoted by the French jurist, Cleirac in 1661, as noted by Twiss, n 23, vol 2, p xlviii (i.e. that they were drawn up by Eleanor after her return from the Holy Land). Shephard, n 589, pp 218-9 mentioned other theories, now discounted. It seems Oleron itself became a commune by a charter of Eleanor c.1199, see Twiss, n 23, vol 2, p xxv.

${ }^{607}$ McFee, n 601, p 63 'Eleanor...Duchess of Acquitaine...when she brought back the Assizes of Jerusalem from her sojourn in Palestine, she ordered that they were to be incorporated in laws of her court at Oleron.' See also Twiss, n 23, vol 4, p xxi and Studer, n 520, p xxxiv.

608 Twiss, n 23, vol 1, p lxii 'The better opinion would seem to be that [the Laws] were the result of certain legal privileges granted by the Dukes of Guienne to the Commune of Oleron, prior to the island passing into the possession of British Crown upon the marriage of Eleanora, daughter and heiress of William, Duke of Guienne, with Henry II of England, amongst which privileges was that of the prudhommes of the Commune exercising jurisdiction in maritime matters, and adjudicating on them in the Court of the Mayor, according to the usages of the sea, and the customs of merchants and mariners.' Cited by Shephard, n 589, p 219, fn 84. See also Mears, n 520, p 325.

${ }^{609}$ See N Coureas, The Assizes of the Lusignan kingdom of Cyprus (Nicosia, 2002), introduction. They were applied to the kingdom of Cyprus after its conquest by Richard I in 1191.

${ }^{610}$ In the period 1260-91, Acre, Tyre and other latin towns in Syria and Palestine were lost to the Moslems.

${ }^{611}$ See Twiss, n 23, vol 4, pp 500-19. Twiss took his translation from a $14^{\text {th }}$ century manuscript located in the Royal Library of Munich. Coureas, n 609, took his translation from Greek manuscripts of $1469 \& 1512$.
} 
maritime court as a divisional court of the Court des Bourgeois (Court of the Burgesses). It was called the Court of the Chain since a chain was drawn across the entrance to the port to protect vessels lying within. ${ }^{612}$ However, although these Assizes of Almaric contain provisions on maritime law ( 7 articles), ${ }^{613}$ the Laws of Oleron comprise many more (24 or more, depending on which version is considered). Therefore, the Laws cannot be said to be the same as the Assizes since they are more extensive.

- Edward I. The Laws of Oleron entered Castilian law - c.1266 - in the fifth part of the Seven Part Code (Las Siete Partidas) ${ }^{614}$ of king Alfonso X of Castile (1252-84). ${ }^{615}$

- Since Alfonso was the brother-in-law of Edward I (1272-1307) it is likely that Edward and his court would have been aware of the Seven Part Code, including the Laws of Oleron ( if not previously aware of them, via Richard I). Thus, it may be that Edward I promulgated the Laws of Oleron, since the English version of the Laws corresponds closely with that of the Spanish; ${ }^{616}$

- The difficulty with this is that an Ordinance made by Edward I at Hastings in 1274 made no mention of the Laws of Oleron ${ }^{617}$ and a judgment of Edward I in 1285 conflicted with them. ${ }^{618}$ Thus, it seems unlikely he made them.

There is another problem with the Laws of Oleron. There never was a universally accepted text. ${ }^{619}$

- Originally 24 Articles. Likely, the Laws of Oleron, originally, comprised some 24 articles in French. ${ }^{620}$ Further, it seems that, in the reign of Edward III (1327-77) - possibly in $1339-11$ additional articles

\footnotetext{
${ }^{612}$ An article of the Assizes of Almaric I, cited by Twiss, n 23, vol 4, pp 500-1, stated: 'Here you have in what way king Amauri established what should be the law of mariners and of vessels and of ships... as regards those who navigate the sea, if it happens that they have any dispute with their mariners about a jettison from bad weather or from any other cause that regards the ship, the laws commands that the matter should be adjudged by the court of the sea, because in the court of the sea the wager of battle is not admitted as a mode of proof, nor in support of any claim during the voyage...' See also Ballard I, n 51, p cxxxi.

${ }^{613}$ See Coureas, n 609, art 41 (what king Almery [Almaric] ordained on how the law of seafarers should be); art 42 (where goods are taken to a destination not agreed); art 43 (things which must be thrown overboard on account of bad weather); art 44 (seafarers who change their mind); art 45 (prohibited materials to Muslim lands); art 46 (goods seized by pirates or lost due to shipwreck), art 47 (things thrown overboard, entitlement of finder). See also Latin version, arts 44-8.

${ }^{614}$ Twiss, n 23, vol 1, pp 1xvii-ix. See also SP Scott (trans), Las Siete Partidas (Univ. of Pennsylvania Press, 2001), vol 4 containing the $5^{\text {th }}$ Partida (Obligations and Maritime Law). There is debate as to whether the Seven Part Code became part of Castilian law. It is thought to have been completed in 1266. See also Studer, n 520, xxxix.

${ }^{615}$ Also called Alfonso the Wise (1221-84).

${ }^{616}$ Twiss, $\mathrm{n} 23$, vol 1, p lxvii noted that the Black Book version of the Laws of Oleron was identical to a copy in the Guildhall of the City of London and that there was an identity between them and a Castilian version contained in A de Capmany, Codigo de las Costumbres Maritimas de Barcelona (1791). The latter text referred to Laws of Oleron ('con el qual acuerdan todas las leyes que estan en el titulo de la quinta Partida' [trans. 'with which accords all the laws which are in the title of the fifth Part']. Carter, n 27, pp 160-1 'There is...a tradition...that the Rolls of Oleron were adopted in Castile by Alphonso X in the thirteenth century as positive law in suits between merchants and mariners, and that the laws in the fifth Partida of ...the Siete Partidas were framed in accordance with the rolls.' See also Shephard, n 589 , p 239 who also noted, $\mathrm{p}$ 240 'The strategic importance of Oleron to the Plantagenets is confirmed by the fact that in 1252 Henry III gave the island to his son Edward under the condition that it never be separated from the Crown.'

${ }^{617}$ See Twiss, n 23, vol 1, p lxix and p 69. Also, Pritchard, n 218, p 27 (M Hale, Treatise on Admiralty c. 1676).

618 Thornely. n 32, p 9 'In 1285 complaints were made to the king by the barons of the Cinque Ports that the merchants of Gascony, England, Wales and Ireland were in the habit of compelling English shipowners to contribute for jettison on vessels, apparel and stores, and it was held by Edward I [1272-1307] that only merchandise should so contribute, thus overruling the Roman law rule and the judgments of Oleron [see Twiss, n 23, vol 1, p 97, Laws of Oleron, art 8], which empowered the shipmaster to sell furniture and merchandise for the expenses of the ship.' See also Twiss, n 23, vol 1, pp lxx, 97 and 127 and vol 2, p xxxiii-iv; Carter, n 27, p 162; Marsden II, n 520, vol p viii and pp 50-1 note; Liber Albus, n 42, pp 421-2 and Pritchard, n 218, p xxxvi.

${ }^{619}$ Shephard, n 589, p 209 noted some 44 manuscripts.

${ }^{620}$ G Miege, The Ancient Sea-Laws of Oleron, Wisby and the Hanse Towns (London, 1686), p 1 'these laws were written in the old French, after the Gascon dialect and not in English; they were made particularly for Bordeaux voyage, for the lading of wines and other commodities in the said place, and for the transporting and unloading of them at S Malo, Caen, and Rouen, sea port towns of France; and lastly, that there is not so much as any mention made of the Thames, England, or Ireland.'
} 
were treated as being part of the Laws of Oleron, although they were not there originally. ${ }^{621}$ The first printing of the Laws of Oleron appears to have been in 1485 and the first English translation in $1528{ }^{622}$

- Subsequent Additions. There was also a Brittany version of the Laws of Oleron, with 26 articles. ${ }^{623}$ And, in 1483, a French mariner, Pierre Garcie Ferrande came up with a version of the Laws of Oleron comprising 47 articles. $^{624}$ So did a French legal writer, Cleirac, who followed him and who wrote in 1647. However, Cleirac (incorrectly) attested a date of 1266 for all 47 articles of Garcie when it was clear that Garcie has asserted that only the first 26 articles bore that date (a mistake that was to cause much confusion to later writers); ${ }^{625}$

So, what is the truth of the matter, now that we know that there were many versions of the Laws of Oleron? And, that Richard I never visited Oleron after his crusading?

- French Language. It is difficult to believe that the Laws of Oleron are other than French laws (judgments or customs) since, it seems to be widely accepted that the original language was French;

- Island of Oleron. It is also difficult to believe that the Laws did not originate from the island of Oleron since that island has been consistently associated with them; ${ }^{626}$

- Wine Trade. Shephard (as did Miege and Studer) thought that the Laws of Oleron were linked to the wine trade. $^{627}$ This seems plausible, given references in the Laws to various places on the wine route. Therefore, these Laws may have originated as a charter under seal entered into between shippers on the wine route, regulating their voyage, ${ }^{628}$ one which - given its utility - was later applied generally. Alternatively, they may have been, originally, decisions (judgments) of a maritime court sitting at Oleron;

- English Law. It is reasonable to suppose that the Laws were enacted as part of English law by: (a) Richard I; ${ }^{629}$ or (b) Eleanor on his behalf; or (c) Edward I. ${ }^{630}$ Certainly, Oleron was part of the

\footnotetext{
${ }^{621}$ See Shephard, n 589, pp 210-1 \& 215-6 and Pritchard, n 218, p xxxvi. Ibid, p 60 (Hale, Treatise on Admiralty c.1676). Hale thought the Laws of Oleron comprised some 26 Articles with 'the rest added by the usage or customs or practice of the several countries where the laws of Oleron were received.' Cf. Twiss, $\mathrm{n} 23$, vol 3, pp xi-ii.

${ }^{622}$ See R Copland, The Rutter [i.e. Routiers, Rules or Sailing Directions] of the Sea ( $1^{\text {st }}$ ed, 1528). Copland took his version of the Laws of Oleron from Garcie, see n 624. A reproduction of Copland and Garcie is contained in D Waters, The Rutters of the Sea, the Sailing Directions of Pierre Garcie (Yale University Press, 1967) who asserted, p 38, that the first printing of the Laws of Oleron was in 1485 in Coustumes de Bretaigne, Lantreguer [Treguier] 1845 (the title was 'Jugemens de la Mer').

${ }^{623}$ See Shephard, n 589, pp 209-10. Also, Twiss, n 23, vol 1, p lxiv and vol 2, pp lvi-ii.

${ }^{624}$ G De Ferrande (Pierre Garcie), Grand Routier de la Mer (it was first published in Rouen between 1502-10). Twiss, n 23, vol 2, p lxxx thought that Ferrande took his version of the Laws of Oleron from a Breton source. Cf. Shephard, n 589, p 208, fn 8 .

${ }^{625} \mathrm{E}$, Cleirac, Les Us et Coustumes de la Mer (1647). For an early English translation, see Justice, n 555 (1705), pp 234-48 which text was used by Lord Tenterden. For the differences between Cleirac's and Ferrande's versions, see Twiss, n 23 vol 2, p 433. Cleirac's text was used by Sir Leoline Jenkins when acting as a judge in the HCA as well as by Mansfield CJ. See also a translation in R Peters, Admiralty Decisions in the District Court of the United States for the Pennsylvania Districts (1807), vol 1. See also Studer, n 520, xli. For the incorrect dating by Cleirac, see Waters, n 622, pp 38-9.

${ }^{626}$ Shephard, n 589, p 240 'all the evidence suggests that the island of Oleron was the likely place where the text was first complied.' This was asserted by some civilians early on. W Welwood, An Abridgement of all Sea-Lawes (1613), Epistle 'law of Oleron; a forraine [foreign] law, as all the other laws of the Admiral court commonly are, whereof no other judicature here can take cognisance'. Ibid, p 3 'on the great ocean, which is our sea, the first laws we know to be made, were devised by them of the island of Oleron.... which are therefore called La rool d'Oleron; as by which the controversies of the sea coast of France toward the ocean were ordinarily decided, in the town of the said isle, called thereupon, la vile de droict, or Oleron. As where the skilled skippers in that law did dwell, and had cognition of all such occurrent debates and questions.' ${ }^{627}$ Ibid, p 212 'The subject matter...is the wine trade between the South-West of France and Northern Europe.' See also Miege, n 620. (whom Shephard did not cite) and Studer, n 520, p xxxvii. The wine trade with England was huge. For example, 141 vessels carrying 13,429 tons of wine to London in 1350, see Sanborn, n 35, p 370. Pritchard, n 218, p xxxiv 'The judgments of Oleron entered English maritime law apparently in consequence of trade with Acquitaine and Bordeaux, not as a result of any political decision or legislative act by English kings who were dukes of Acquitaine.'

${ }^{628}$ Ibid, p 245 who noted that the earliest manuscript of the original version of the Laws of Oleron referred to the text as 'Carte d'Oleron'. Ibid, p 246 'rules to be followed by the participants to [a] maritime adventure.' Ibid, p 248.

${ }^{629}$ Abbott, $\mathrm{n}$ 591, (in 1802), $\mathrm{p}$ vii took an equivocal position. He referred, in his introduction to: 'the Ordinance of Oleron (which being considered as the edict of an English prince, has been received with particular attention in the court of Admiralty)' and yet 'they have not the binding force or authority of law in this country...' Cf. Scrutton, n 188, p 179 'laws of Oleron...which was expressly embodied in the laws of England.' See also Studer, n 520, p xxxv.

${ }^{630}$ Shephard, n 589, p 238 thought the Laws originated in Oleron in the period 1204-24. This discounts (a) and (b). Reddie I, n 520, p 418 (writing in 1841) thought that the Laws of Oleron were never expressly enacted in England but 'acquired a kind of indirect legislative authority.'
} 
English Crown after Eleanor married Henry II of England. Thus, their application would not have been problematic. Indeed, they may simply have become part of English law by way of custom since the wine trade with England was considerable. Thus, shippers may have agreed with English merchants and financiers that these were the terms on which shipment should be made.

As for references to the Laws of Oleron in early English law:

- English Cases. The Laws of Oleron were referred to in Pilk v Venore (1349) ${ }^{631}$ as well as in cases concerning general average in $1370{ }^{632}$ and cruelty to seaman in $1455 .{ }^{633}$ However, it also seems clear that their application did not override English law. ${ }^{634}$ Also, the Laws of Oleron were scant so that even if they were part of English law - they left plenty of opportunity for the common law and local English maritime custom to slip in; ${ }^{635}$

- Inquisition of 1375. The Laws of Oleron were referred to at an Inquisition taken at Queensborough by command of Edward III (1327-77) in 1375. This directed, inter alia, that inquiry be made of: 'all mariners who do lay violent hands upon or beat their masters against the laws of the sea and the judgments of Oleron thereupon made.'; 636

- Petition by Parliament - 1402. A petition of the Commons in 1402 - one which claimed that the admirals were abusing their jurisdiction - requested: 'let the said admirals exercise their laws solely according to the law of Oleron and the ancient laws of the sea, and by the law of England, and not by custom, nor by any other manner.' 637

Finally, it should also be noted that - even if the Laws of Oleron were part of English law - reference to the Laws of Oleron declined markedly after the medieval period and their terms were superceded by common law cases and legislation. Schomberg (an Oxford don), writing in 1786, noted that the Laws of Oleron 'has long ago grown entirely obsolete. ${ }^{638}$

In conclusion, the Laws of Oleron cannot be said to be part of the law merchant (including any foreign law merchant) since they (likely) comprised English legislation which applied generally. Even if this incorrect and they can be said to be have been part of the law merchant, they were obsolete by the $18^{\text {th }}$ century.

\section{(f) Continental Maritime Laws}

\footnotetext{
${ }^{631}$ H Hall (ed), Select Cases on the Law Merchant (1930), SS, vol 46, pp xcv-i. Judgment was given by the mayor and bailiffs of Bristol in a case in which a shipmaster was held liable for loss of cargo due to theft by the crew. It was certified to the Chancellor as having been given according to the law and custom of Oleron. See also Thornely, n 32, p 8; Carter, n 27, p 161 and Pritchard, n 218, p 33 (M Hale, Treatise on Admiralty c. 1676). However, as Shephard, n 589, p 215, fn 309, noted, it is difficult to see which article of the Laws was being referred to (he thought art 33). Senior, n 520, p 20 'When the laws of Oleron first had authority in English seaports is uncertain, but there is no doubt that they were the recognised code in matters within their scope in the courts of the boroughs long before those of the admirals came into being.'

${ }^{632}$ Shephard, n 589, p 251 'In London, in 1370, a general average claim arising during a voyage from Flanders to England was brought before the mayor and aldermen by certain of the merchants whose goods were jettisoned against other merchants whose goods were jettisoned against other merchants whose goods arrived safely in which the plaintiffs demanded their share of the goods saved in accordance with the Roles d'Oleron.'

${ }^{633}$ See Twiss, n 23, vol 1, pp 253-5. Also, Marsden I, n 520, p liv; Carter, n 27, p 161 and Shephard, n 589, p 251.

${ }^{634}$ See also $n 685$ for a modern statement on this.

${ }^{635}$ Senior, n 520, p 16.

${ }^{636}$ Twiss, n 23, vol 1, p 161. Also, 'concerning all mariners who are rebellious against the honest commands of their masters and of masters who do not keep their mariners quiet at table or elsewhere as the judgments of Oleron do require.' And 'of lodesmen (or pilots) who do take upon them piloting which they know not how to perform, whereby a ship is sunk or a man killed.' See also Pritchard, n 218, p xxxiv \& 73 and Shephard, n 589, p 250 .

${ }^{637}$ Parliament Rolls of Medieval England (Scholarly Digital Editions, which is also on CD), iii, 499 'les dites admiralles usent lour leies soulement par la ley de Oleron et anxiens leyes de la mer, et par la leye d'Engleterre, et nemye par custume, ne par nule autre manere.' Shephard, n 589, p 251 'In 1402, the English Parliament petitioned that the Admiralty apply only the Roles d'Oleron and the ancient laws of the sea and English law, and not customary law.' See also Scrutton, n 188, p 172 and Thornely, n 32, p 28.

${ }^{638}$ AC Schomberg, A Treatise of the Maritime Laws of Rhodes (1786), p 96. Following Coke, he thought, $\mathrm{p} 88$, that Richard I on his return from the Holy Land, rested in Oleron and while there 'gave orders for a work of this kind to be compiled.' Also, that, since Oleron (with other territories in France) was annexed to the English Crown, p 89 'these laws were as much English laws as if Richard had published them in London'. The first statement is factually incorrect. Reddie I, n 520, p 419 (writing in 1841) said of the Laws of Oleron 'trade and navigation underwent such great changes, that the subjects of many articles of this code grew entirely obsolete; and rules more conformable to modern usages and customs came, from time to time, to be recognised or established.' In France, the Laws of Oleron were obsolete (it was asserted) by 1681 , see Waters, n 622, p 41.
} 
There were many sea laws promulgated in medieval times ${ }^{639}$ and even earlier. In respect of the principal ones which influenced English legal writers (and were cited in a few English cases) the following may be noted:

- Greek - Rhodian Law ${ }^{640}$ It was often said this was earliest code of maritime law. One which prevailed at Rhodes, some centuries prior to the Christian era. ${ }^{641}$ It was (it was said) adopted into Roman law by the emperor Augustus.

- Certainly, Rhodian law with regard to average contributions in the event of jettison at sea was part of Justinian's Digest. ${ }^{642}$ However, Ashburner - who undertook a detailed analysis of manuscripts in 1909 - noted that there were many variants in the text of this code of sea laws (comprising some c. 47 articles) as well as great diversity in the title;

- Also, the contents of the earliest manuscript was, probably, only c. AD $600-800 .{ }^{643}$ In short, the Rhodian code changed considerably over time and there was no one definitive version - an important point to note for those English civilians who, later, asserted that there was a maritime ius gentium (see 19);

- Catalan - Consolato Del Mare (Book of the Consulate of the Sea). This code of sea laws, written in the Catalan dialect, was compiled by order of the kings of Aragon or (possibly) in Barcelona or Pisa. It appears to have been first published in Barcelona c. 1494. ${ }^{644}$ However, it is thought to have been compiled no earlier than $1320-40 .{ }^{645}$

- This is important since many early writers on the Laws of Oleron, incorrectly, supposed it to be subsequent to this code. English courts may have made reference to this code in early times, since - unlike the laws of Oleron - it contained provisions on prize;

- However, it also seems clear the English courts never directly adopted the provisions of this code. ${ }^{646}$ Indeed, an Act of 1442 expressly repudiated them re prize. ${ }^{647}$ This code was cited (but not followed) by Tindal CJ in Gould v Oliver (1837); ${ }^{648}$

- Nordic - Laws of Visby. These comprised a code of maritime laws promulgated at Visby (the capital of Gotland in Sweden) in the latter part of the $13^{\text {th }}$ century although they were only first printed in $1505 .{ }^{649}$

\footnotetext{
${ }^{639}$ Malynes, $\mathrm{n} 22$ ( $3^{\text {rd }}$ ed, 1686), vol 1, p 87 asserted that the 'rulers of Rome in the year 1075 made new sea laws and statutes, and so did every chief sea-faring town upon the said Mediterranean coast, adding thereunto other ordinances. So did they of Marseilles in the year 1162; Genoa in the year 1186; they of Peloponessus called Morea, in the year 1200: the Venetians in the year 1262, Constantine 1270, James [I] king of Arragon the said year [actually 1258]; Peter king of Arragon 1340; and they of Barcelona 1434.' McFee, n 601, p 66 'The medieval maritime cities which adopted their own version of the Rhodian code were really city states. Venice, Genoa, Pisa, Amalfi, Bari, Cataro, Ragusa, Trani, Ancona, Curzola, Pera, Spalato, Tortosa, Trapani, Barcelona, d'Amalric, Zara, and Marseilles, all had their own codes or tables of sea law... [their] maritime courts were held on the shore, or 'strand', a tradition handed down from the days of imperial Rome.' Pisa had its Ordo Maris in the $12^{\text {th }}$ century and its maritime ordinances were likely the earliest. For likely dates, see W Ashburner, The Rhodian Sea Law (Oxford, 1909), pp cxv-cxxii.

${ }^{640}$ For a translation, see McFee, $\mathrm{n}$ 601, pp 276-85. The standard work is Ashburner, $\mathrm{n}$ 639. It superceded more dated works, such as: (a) the first translation of the Rhodian sea law by S Schard, De Varia temporum in Jure Civili observatione Libellus item Leges Rhodiorum Navales (1561); (b) C van Bynkershoek, De Lege Rhodia (1703); (c) J Gothofredus, De Imperio Maris et de Jure Naufragii Colligendi Legeque Rhodia (1637); (d) E Meignen, Etude sur la Lex Rhodia de Jactu (1886); (e) Shomberg, n 638; (f) A Vinnius. In Tit. Dig et Cod ad rem nauticam pertinentes Commentarii (1647)(a commentary on Peckius); (g) P Peckius, Commentarii in Titulos Digestorum et Codicis ad rem Nauticam Pertinentes (1556, a collection of sea laws).

${ }^{641} \mathrm{McFee}, \mathrm{n}$ 601, p 35 '[Rhodes] commanded the entrance to the Aegean Sea...It stood at the crossroads of the Mediterranean set routes. It was a depot for the transhipment of freight for the Golden Horn, the ports of the Euxine, and the long, profitable haul to the metropolis on the Tiber.' See also ch 5 .

${ }^{642}$ See A Watson (trans), The Digest of Justinian, University of Pennsylvania Press (1985), bk 14, title 2 (the 'Rhodian Fragment'). See also Ashburner, n 639, p cclii. Coquillete, n 13, p 128, 'Citations to civil law sources outside of Digest 14.2 (The Rhodian Fragment) were extremely rare, and most likely limited to references to the Institutes 3.13 (De Obligationibus).'

${ }^{643}$ Ashburner, $\mathrm{n} 639, \mathrm{p}$ lx 'in the manuscripts used for this edition there are the greatest diversities both as to the title and as to the contents.' He also thought, $\mathrm{p}$ cxiii 'Some provisions which originally had nothing to do with maritime affairs have been doctored in order to bring them within the purview of the sea-law.'

${ }^{644}$ F Celelles (ed), Il Consolato del Mare (c. 1494). For a translation and commentary, see Twiss, n 23, vol 3. Also, McFee, n 601 , p 45.

${ }^{645}$ Modern analysis suggests that: (a) the Laws of Oleron; (b) Laws of Visby; (c) Consulate of the Sea were, historically, in that order. Thus, commentary of Twiss, $\mathrm{n} 23$ (or other, older, legal writers) to the contrary should be discarded.

${ }^{646}$ Senior, n 520, p 52 'It is doubtful whether the other prize-law principle of the Consolat that neutral goods should go free in enemy ships (subject as therein mentioned) was ever accepted English policy, but the fact of a statute being passed in 1442 expressly repudiating it [20 Hen $6 \mathrm{c}$ 1] may be evidence that there was likelihood about that time of its adoption by English admiralty courts.'

${ }^{647} 20$ Hen 6 c 1 (rep 1863). See also Pritchard, n 218, p 64 (M Hale, Treatise on Admiralty c. 1676).

${ }^{648} 4$ Bing NC 134 (132 ER 740) at $\mathrm{p} 142$.
} 
Visby was where the Hanseatic League was headquartered until $1361 .{ }^{650}$ These laws were based on the laws of Oleron ${ }^{651}$ and the Consolato del Mare and they were adopted as the commercial law of northern Europe. Various ordinances were also issued by the Hanse towns in 1597 and 1614; ${ }^{652}$

- Italian - Code of Amalfi. The first modern maritime code -the Tabula (Tavola) Amalfitana (also called the Amalfitan Table or Tavole Amalfitane) - was compiled in the $12^{\text {th }}$ century in Amalfi, an Italian town on the gulf of Salerno; ${ }^{653}$

- French - Ordonnance de la Marine 1861. This comprised an Ordinance of Louis XIV (1643-1715) published in August 1681which codified the law on shipping. ${ }^{654}$ It codified prior French law on the matter and it was inspired by the customs and statutes of the United Provinces (Amsterdam and Antwerp). Lord Tenterden (Charles Abbott) referred to it in his work on shipping. ${ }^{655}$

Duck, in his De Usu et Authoritate Juris Civilis (1653), stated, with regard to the practice of the HCA in his time:

Besides the civil law in the admiral court, the laws of Oleron, made by Richard I who was in possession of that island, are in use; and also the Marine Constitutions, published by several princes at Rome, Pisa, Genoa, Marseilles, Barcelona, Messina, and other places; together with the customs set down in the public acts of that court. ${ }^{656}$

However, it is asserted that these laws, which all had much in common, ${ }^{657}$ were only persuasive in value, even in the HCA (also, they are no evidence of a maritime ius gentium) ${ }^{658}$ They were not binding on the English courts in maritime matters - just as Roman law was not binding on the English courts in maritime matters, but only of persuasive value; a position similar to that prevailing today. ${ }^{659}$ The same applied to the many foreign writers on maritime law referred to by English legal writers on maritime law such as: ${ }^{600}$

\footnotetext{
${ }^{649}$ For commentary and text see Twiss, n 23, vol 4. See also McFee, n 601, pp 73-4. For an older text see Miege, n 620.

${ }^{650}$ For a useful note on the League see McCulloch, n 396 (Hanseatic League) 'an association of the principal cities in the north of Germany, Prussia etc, for the better carrying on of commerce, and for their mutual safety and defence.'

${ }^{651}$ A number of early texts on maritime law erroneously supposed that the laws of Visby pre-dated the Laws of Oleron.

${ }^{652}$ Malynes, n 22 ( $3^{\text {rd }}$ ed, 1686), vol 1, pp 125-9 provided an abridgment of the 1614 laws. See also R Kuricke, Jus Maritimum Hanseaticum (1667)(it contains the Ordinance of 1614 with commentary), Schomberg, n 638, pp 101-9 and Justice, n 555, pp 249-56.

${ }^{653}$ For commentary and text see Twiss, n 23, vol 4; McFee, n 601, pp 67-73 and Zouch, n 19 (for which, see Malynes, n 22 (3 ${ }^{\text {rd }}$ ed, 1686) which contains his text), vol 1, p 88. See also Mears, n 520, p 323.

${ }^{654}$ L'Ordonnance de la Marine du Mois D'Aout 1681. For commentary see RJ Valin, Nouveau Commentaire sur L'Ordonnance de la Marine (Rochelle, 1760). For a translation and commentary in English see Justice, n 555, p 293 et seq.

${ }^{655}$ Abbott, n 591, p vi.

${ }^{656}$ Duck, n 598, p xxxv.

${ }^{657} \mathrm{McFee}, \mathrm{n}$ 601, p 51 'In general the matters treated of in all the codes may be broadly classified into: (1) relationship between the master or captain and the owner and merchants; (2) duties of the master towards the crew, and vice versa; (3) precautions to be taken in the case of shipwreck; (4) the principle of 'contribution', or the obligation of all on board to participate in (a) saving the ship and cargo and (b) reimbursing those whose property is lost by jettison, piracy, or sea water in the effort to save the ship and all on board; (5) relationship between partners in a 'sea adventure' and the importance of the contract being in writing and not merely oral; (6) relationship between the master and the 'lodman' or pilot who conducts a ship into a port with which the captain is not familiar; (7) warning against the theft of vital equipment, such as anchors, from a ship, which may imperil the voyage and lose the ship; (8) the binding of all on board with an oath to stand by one another until the voyage is completed.'

${ }^{658}$ Shephard, n 589, p 252, in respect of the Laws of Oleron 'no basis for concluding that such practices and customs represented a universal body of law'. This applies to all the other foreign maritime laws I have cited. Although there was some commonality there was also a lot of diversity and no uniform text in respect of the early material. Indeed, the French Ordonnance of 1681 is really the starting point for modern maritime legislation which is uniform and internally consistent.

${ }^{659}$ Kiralfy, n 208, pp 103-4 'It is doubtful how far Roman law was binding in maritime cases not covered by these laws or 'judgments.' The civil law has been cited in court in connection with modern Admiralty law [he cited The Turbantia [1924] P 78 at pp 86-7 per Sir Henry Duke, President], but it had only a persuasive influence, where the law is deficient [he cited The Gas Float Whitton [1896] P 42, pp 47-8]. There is some authority for saying that in the seventeenth century the civil law had only a persuasive influence, and, since in that century the sea laws were administered in the [HCA] where the judges and advocates were doctors of the civil law, it is still less likely that the Roman Corpus Juris was binding on the local courts in the earlier period.'

${ }^{660}$ See generally, W Senior, Early Writers on Maritime Law (1921) 37 LQR 323-36.
} 
- French. Azuni (1810), ${ }^{661}$ Boucher (1808) ${ }^{662}$ Cleirac (1647) ${ }^{663}$ Desjardins (1890), ${ }^{664}$ Emerigon (1780) ${ }^{665}$ Ferrande (1542), ${ }^{666}$ Pardessus (1828-45), ${ }^{667}$ Pothier (1764), ${ }^{668}$ Valin (1760), ${ }^{669}$ Voisin (1584); ${ }^{670}$

- Italian. Ansaldi (1689), ${ }^{671}$ Casaregis (1719), ${ }^{672}$ Ferretus (1579), ${ }^{673}$ Roccus (1655); ${ }^{674}$

- $\quad$ Dutch. Peckius (1556), ${ }^{675}$ Vinnius (1647); ${ }^{676}$

- German. Heineccius (1740), ${ }^{677}$ Loccenius (1650), ${ }^{678}$ Kuricke (1667), ${ }^{679}$ Schardius (1561), ${ }^{680}$ Stypmannus (1652); ${ }^{681}$

- $\quad$ Spanish. Augustin (1591) ${ }^{682}$ Bolanos (1615). ${ }^{683}$

In Victorian times, in the The Gas Float Whitton, No 2 (1896), Esher MR stated the position as to these foreign maritime laws and writings:

Neither the laws of the Rhodians, nor of Oleron, nor of Wisbuy, nor of the Hanse towns, are of themselves any part of the admiralty law of England ${ }^{684}$...But they contain many valuable principles

${ }^{661}$ MDA Azuni, Origine et Progres du Droit et de la Legislation Maritime, avec des observations sur le Consulat de la Mer (Paris, 1810). Azuni (1749-1827), an Italian by birth, became French, and was a judge in the maritime and commercial court of Nice.

${ }^{662}$ PB Boucher, Consulat de la Mer (Paris, 1808). Also, Institution au Droit Maritime (Paris, 1803). Boucher was a professor of commercial and maritime law in the Academy of Legislation of Paris.

${ }^{663}$ See $\mathrm{n}$ 625. Cleirac was an advocate in the Court of Admiralty in Bordeaux.

${ }^{664}$ A Desjardins, Introduction Historique a l'Etude du Droit Commercial Maritime (1890). Desjardins (1835-1901) was a French jurist and magistrate.

${ }^{665}$ BM Emerigon, Nouveau Commentaire sur L'Ordonnance de la Marine (1780). Also, Traite des Assurances et des Contrats a la Grosse (1783), trans by S Meredith as $A$ Treatise on Insurances (Butterworth, 1850). Emerigon (1716-85) was a judge in the Court of Admiralty in Marseilles.

${ }^{666}$ Ferrande, n 624. See also JH van Linschoten, Le Grand Routier de Mer (1619). Also, Guidon de la Mer (compiled c. 1556, pub 1607, written by an unknown writer for the use of merchants at Rouen it is contained in Cleirac, see n 625). See also Senior, n 660, pp 326, 333.

${ }^{667}$ JM Pardessus, Collections de Lois Maritimes Anterieures au XVIIIieme Siècle (Paris, 1828-45). See also Us et Coutumes de la Mer (1847). Pardessus (1772-1853) was a French jurist.

${ }^{668}$ RJ Pothier, Traite des Contrats de Louage Maritimes (1764). See C Cushing (trans) Treatise on Maritime Contracts of Letting to Hiring (Boston, 1821). Pothier (1699-1772) was a judge of the Presidial Court of Orleans and a professor of law at the University of Orleans, France.

${ }^{669}$ See $\mathrm{n}$ 654. Valin (1695-1765) was an advocate and king's counsel in the Court of Admiralty in Rochelle.

${ }^{670}$ L Voisin, L'Amiral de France (Paris, 1584). An account of the office of admiral. See also Senior, n 660, p 333.

${ }^{671}$ Ansaldo Ansaldi, Discursus Legales de Commercio et Mercatura (1689). Ansaldi (1651-1719) was a Roman lawyer.

${ }^{672}$ GLM Casaregis, Discursus Legales de Commercio (Legal Discourses on Commerce, $1^{\text {st }} \mathrm{ed}, 1719$, last ed 1740). Casaregis (1670-1737) was a law professor and counsellor to the Grand Duke of Tuscany. His text contained the Consolato del Mare, with commentary.

${ }^{673}$ J Ferretus (or Ferreti), De Jure et Re Navali (Venice, 1579). Ferretus was an Italian jurist. See also Senior, n 660, pp 330-1.

${ }^{674}$ F Roccus (Francesco Rocci), Notabilia de Navibus et Naulo item de Assecrationibus ('Remarks on Ships and Freight and on Insurance')(Naples, 2 vols, 1665. The 1708 edition was translated by JR Ingersoll, A Manual of Maritime Law in 1809, rep. Lawbook Exchange Ltd, 2007). Roccus was a jurist of Naples and judge of the Magna Curia (Supreme Court).

${ }^{675}$ See $\mathrm{n}$ 640. Petrus Peckius or Peter Peck (1529-89) was a law professor at Leuven (Louvain). See also Senior, n 660, p 331. Peckius was cited by Hale in his Treatise on Admiralty c.1676, see Pritchard, n 218, p 58.

${ }^{676}$ Ibid. Vinnius (also called Vinnii or Vinnen, 1588-1657) was a law professor at Leiden who prepared an annotated reprint of Peckius, see $n$ 675.

677 JG Heineccius, Scriptorum de Jure Nautico et Maritimo Fasciculus (1740). Heineccius (1681-1741) was a professor of philosophy and jurisprudence at Halle.

${ }^{678}$ J Loccenius, De Jure Maritimo et Navali (Stockholm, 1650). Loccenius (John Locken)(1598-1677) was a German jurist and historian whose text comprised a commentary on Swedish maritime law.

${ }^{679}$ See n 652. Also known as Reinhold Curicke (1610-67), he was a jurist and historian from Danzig.

${ }^{680}$ See $\mathrm{n}$ 640. Simon Schard (1535-73) was a member of the College of Assessors to the Imperial Supreme Court at Speier. See also Senior, $\mathrm{n}$ $660, \mathrm{p} 332$.

${ }^{681}$ JF Stypmannus, Jus Maritimum et Nauticum (1652). Franz Stypmann (1612-52) was a law professor at Greifswald University, Germany.

${ }^{682}$ A Augustin, De Legibus Nauticis (Tarragona, 1591). Augustin was a Spanish jurist, at one time a papal nuncio in England. See also Senior, n 660, p 334.

${ }^{683} \mathrm{~J}$ de H Bolanos, Curia Philipica (Lima, 1615). Bolanos (1570-1623) was a Spanish jurist. See also Senior, n 660, p 334.

${ }^{684}$ In particular, Lord Esher cited various articles of the Laws of Oleron which he considered it 'would be ridiculous to suggest that they are part of English law', see pp 47-8, art 23 ('if a pilot through ignorance causes the ship to mis-carry he shall make full satisfaction or lose his head'), art 24 ('if the master or one of his mariners or any one of the merchants cut off his [the pilot's] head, they shall not be bound to answer for it') and art 26 ('if the lord of any place be so barbarous as to maintain [wreckers] he shall be fastened to a post or stake in the midst of his own mansion-house, which, being fired at the four corners, and shall be burnt together etc.)'. See also Mears, n 520, p 327. 
and statements of marine practice which, together with principles found in the Digest and in the French and other Ordinances, were used by the judges of the English court of Admiralty, when they were moulding and reducing to form the principles and practice of their court. ${ }^{685}$

There was nothing new in this, since Abbot had said much the same in the first edition of his text on Shipping in $1802 .{ }^{686}$ Further, today, it is possible to confirm - thanks to the English Reports (1220-1873) being online and with word search - that, in fact, the English courts rarely referred in their judgments on maritime matters to foreign laws or foreign writers or, indeed, to the Laws of Oleron. ${ }^{687}$ The same applies with regard to the Selden Society reports ${ }^{688}$ and the relatively scant reports on maritime law until modern times. ${ }^{689}$

\section{(g) Conclusion}

To the extent English maritime courts were applying the law merchant (including any foreign law merchant or customs) the following may be stated:

- Courts. Local maritime courts were superceded by the HCA - mainly by the $16^{\text {th }}$ century - although they were not finally abolished until the Municipal Corporations Act 1835 (with the exception of the Cinque Ports' Admiralty Court, now obsolete). Vice-Admiralty courts, likely, ended by the early $19^{\text {th }}$ century. The HCA, which existed from c 1340 became part of the High Court in 1875;

- Local Maritime Customs. To the extent local maritime customs comprised part of the law merchant (merchants and mariners often being the same in early times) from the few custumals in existence, it is probable that they died out the same time as local maritime courts. ${ }^{690}$ Thereafter, there would have been little incentive for the borough courts or the HCA to preserve them. To the extent they became borough customs, since 1974 only metropolitan boroughs have existed, such as in London; ${ }^{691}$

- Foreign Maritime Customs. Later claims by English civilian writers that local maritime courts and the HCA applied foreign maritime customs (see 19) must be treated with circumspection.

- In earlier times, it was thought the Laws of Oleron were part of English law and it was only in the $19^{\text {th }}$ century that this was openly challenged, albeit Hale (c. 1676) had been skeptical of the tradition that they had been promulgated by Richard I. In any case, these Laws were obsolete by the late $18^{\text {th }}$ century, being redundant or superceded by English legislation or the common law;

- As to other foreign maritime laws - including those referred to in (f) - while these may have been quoted by civilians (not least, as part of their defence of the HCA) such early English maritime caselaw as there exists - as well as other caselaw - indicates no direct application of the same. Indeed, they were (generally) rarely cited. This is not wholly surprising since there was confusion whether they pre or post-dated the Laws of Oleron as well as a failure to realise (until the late $19^{\text {th }}$ century) that there were many versions and much inconsistency.

- Maritime Law. With the first English shipping legislation in 1660, there was an increasing tendency to treat maritime law as a distinct area of law, separate from the law merchant (commercial law). One which continues to this day.

\section{In conclusion, to the extent the law merchant comprised maritime customs - local or foreign - which were}

\footnotetext{
${ }^{685}$ [1896] P at pp 47-8. See also Holdsworth, n 26, vol 1, p 559. The Gaetano and Maria (1882) 7 PD at p 143 per Brett LJ 'the first question raised in the argument before us was what is law which is administered in an English court of Admiralty whether it is English law, or whether it is that which is called the common maritime law, which is not the law of England alone, but the law of all maritime countries. About that question I have not the smallest doubt. Every court of admiralty is a court of the country in which it sits and to which it belongs. The law which is administered in the Admiralty Court of England is the English maritime law...it is the law which the English Court of Admiralty, either by Act of Parliament or by reiterated decisions and traditions and principles, has adopted as the English maritime law.'

${ }^{686}$ See $\mathrm{n}$ 952. R Wiseman, The Law of Laws (London, 1686), pp 229-30, seems to have thought that the Laws of Oleron were not part of English law, but were of the same ilk as Justinian's Digest which provided 'the best and richest treasury of legal reason and equitable knowledge.'

${ }^{687}$ The English Reports are online, see westlaw.uk (Sweet and Maxwell) and lexisnexis.co.uk (Thomson Reuters).

${ }^{688}$ See SS, vols 1-128 and SS website, selden.society.com. Also www.wshein.com/ which has put SS vols 1-99 online.

${ }^{689}$ For early maritime law reports see Sweet \& Maxwell, n 320, vol 1, pp 355-6. For example, RG Marsden (ed), W Burrell, Reports of Cases determined in the High Court of Admiralty temp Sir Thomas Salusbury and Sir George Hay Judges 1758-1774 (1885), p 87 (Counsel referred to Scaccia, see n 754) and p 116 (a reference to Hanseatic law, see 17(f)). Neither determined the case.

${ }^{690}$ Twiss, $\mathrm{n} 23$, vol 3, p vii noted that 'It is a remarkable fact that almost all the 'costumaries' of the English boroughs have disappeared, and that even the memory of them has in many cases passed away.'

${ }^{691}$ In 1974, municipal and county boroughs were abolished.
} 
upheld in various maritime courts this has not prevailed since, at least, 1835 due to the extinction of local and Vice-Admiralty maritime courts by that date as well as - by that date, if not long before - maritime law being treated as distinct area of law to that of the law merchant.

\section{BILLS OF EXCHANGE \& THE LAW MERCHANT}

Apart from maritime law, the principal area analysed by past writers with respect to the law merchant have been the bill of exchange ('BOE') and the promissory note. The argument has been that these provide evidence that the law merchant (customs of merchants) comprised a distinct area of law, as well as being part of a ius gentium. Further, that this law was only, slowly, incorporated into the common law and legislation. To the contrary, this article asserts that:

- The business practices of merchants were accepted by the courts and became part of the common law no different to any London (or other) customs (following Baker);

- $\quad$ These business practices evidenced no ius gentium (following Rogers); and

- $\quad 90 \%$ of the work of acceptance - whether into legislation or the common law - was completed by 1710 (following Rogers and Holden).

\section{(a) Origin}

There have been various general histories relating to BOE, ${ }^{692}$ as well as a number of early legal texts. ${ }^{693}$ In medieval England most transactions between ordinary people would have comprised the acquisition of goods and livestock at markets and fairs by way of exchange; purchase and sale or on credit terms. While merchants were involved in the same, after the Jews were expelled from England in 1290 (see 3), foreign merchants (especially Italian ones) embraced the function of moneylenders to English monarchs as well as to the aristocracy and inter se. ${ }^{694}$ When, and where, the concept of a BOE originated is unclear. ${ }^{695}$ Moshenskyi, in his History of the Weksel (2008), considered these matters in detail. ${ }^{696}$

- Given that China is credited with inventing paper money, it would seem likely they would have discovered the potential for BOE and the means of their negotiation; ${ }^{67}$

- That said, Moshenskyi thought that Western types of BOE and promissory note originated from Italy 698 since Italians were not only lenders to the popes and the extensive European network of the catholic

\footnotetext{
${ }^{692}$ See generally: (a) Rogers, n 12; (b) Holden, n 375; (c) Holdsworth, n 26, vol 8, p 113 et seq; (d) Moshenskyi, n 343, ch 2.9; (e) Salzman, n 214, ch 2; (f) MM Postan, Medieval Trade and Finance (Cambridge UP, 1973); (g) Unwin, n 446, pp 19-34 (London Tradesmen and their Creditors), for London merchants, see also pp 51-6; (h) Malynes, n 22 (3 ${ }^{\text {rd }}$ ed, 1686), vol 1, pp 269-74; (i) Street, n 16, vol 2, chs 31-9; (j) Cranch, n 16; (k) CHS Fifoot, The Development of the Law of Negotiable Instruments and the Law of Trusts (1938) J of the Institute of Bankers 433-56; (1) E Jenks, Early History of Negotiable Instruments (1893) LQR, vol 9, pp 70-85.

${ }^{693}$ See generally: (a) J Bayley, A Short Treatise on the Law of Bills of Exchange etc (1 $\left.1^{\mathrm{st}} \mathrm{ed}, 1789\right)$; (b) J Chitty, A Treatise on the Law of Bills of Exchange, Checks on Bankers etc (1799); (c) J Chitty, A Practical Treatise on Bills of Exchange, Promissory Notes etc (1834, containing cases from 1602-1834); (d) T Cunningham, Law of Bills of Exchange etc (1 $\left.{ }^{\text {st }} \mathrm{ed}, 1760\right)$; (e) S Kyd, A Treatise on the Law of Bills of Exchange and Promissory Notes $\left(1^{\text {st }}\right.$ ed, 1790, $3^{\text {rd }}$ ed, 1795); (f) P Lovelass, Explanation of the Law concerning Bills of Exchange, Promissory Notes etc (1789); (g) T Mortimer, Treatise on Bills of Exchange (1794); (h) W Stevenson, A full and practical treatise upon Bills of Exchange (1764); (i) Obscurities and Defects of the Mercantile Law considered in an Essay on Bills of Exchange (1769); (j) J Byles, A Practical Compendium of the Law on Bills of Exchange etc (1789); (k) W Forbes, A Methodical Treatise concerning Bills of Exchange (1703); (1) EW Manning, The Laws of Bills of Exchange etc (1801). See also J Marius, Advice concerning Bills of Exchange (London, $4^{\text {th }}$ ed, 1684 , printed in Malynes, $\mathrm{n} 22$ (3 ${ }^{\text {rd }}$ ed, 1686), vol 2, pp 23-42. The first edition was in 1651.

${ }^{694}$ Unwin, n 446, pp 27-8.

${ }^{695}$ Bewes, n 34, p 45 noted 'Many writers...have asserted that the [BOE] was invented by the expelled Jews as a means of withdrawing their capital left behind in France...'He rejected this, referring, inter alia, to Assyrian tablets and the Bible. Kyd, n 693 (1795 ed), p 2 'About the middle, or towards the end of the thirteenth century, the Jews, driven by the exactions of the prince, from England and France, took refuge in Lombardy, and from thence gave to merchant strangers and travellers, secret letters on those to whom they had entrusted their effects in the former countries; who honourably discharged the trust reposed in them, by complying with the orders contained in these letters. In the course of time these letters received a fixed form, and had conferred on them the name of bills of exchange.' See also Moshenskyi, $\mathrm{n} 343$, $\mathrm{p} 14$.

${ }^{696}$ Moshenskyi, n 343. The term 'weksel' for the title of his book he took from the German 'wechsel' a composite term which referred to both the BOE and the promissory. He stated, p 7 'The author wrote this book in the context of continental law, more specifically in the context of German weksel law. In this connection, there were some terminological complexities. The concepts of promissory note and bill of exchange, developed in the system of British-American law, do not correspond absolutely to the concepts of continental law.'

${ }^{697}$ Ibid, p 48 et seq. Blackstone, n 186, vol 2, p 467 thought the Mongolians invented them, stating 'in 1236 the use of paper credit was introduced into the Mogul empire in China.' Coquillette, n 13, p 250 'Bills of exchange, as such, were not known to classical Roman law...' See also Scrutton, n 188, p 185.

${ }^{698}$ Ibid, p 9 'Research shows that the West European type weksel (i.e. the bill of exchange in its classical meaning) appeared in Italy in XII-XIII centuries.' Ibid, p 19. Holdsworth, n 26, vol 8, p 136 'I should be inclined to take the view that the idea of the [BOE] originated in the customs
} 
church, they were also major participants in international fairs which became clearing houses for settling debts. ${ }^{699}$

As it is, in medieval times, BOE helped circumvent the Biblical prohibition on usury as well as being a safer and easier - means of transporting money than coin. ${ }^{700}$ Older terms for BOE were 'letters of request ${ }^{701}$ and 'letters of exchange'. The word 'bill', itself, meant no more than that: a letter. In respect of BOE - prior to analysing the extent to which the law merchant was involved - the following historical points may be noted:

- $\quad$ First Legislation. A proclamation in 1283 prohibited BOE drawn abroad on England since silver was thereby taken out of the country and none brought in. ${ }^{702}$ An Act of 1379 also referred to BOE; ${ }^{703}$

- $\quad$ First Use of BOE. Richard I (1189-99) used letters of credit as did king John (1189-1216), although these cannot be equated with BOE. ${ }^{704}$ Whether BOE's existed in England from the $13^{\text {th }}$ century has been much discussed ${ }^{705}$ and is, really, a matter of interpretation since financial instruments similar to them underwent a number of transitions prior to becoming more similar to their modern emanation in the Bills of Exchange Act 1882; $;^{706}$

- $\quad$ First Reported Case - Foreign BOE. It was often asserted that the first reported case on a BOE was in Martin v Boure (1602). ${ }^{707}$ Others have asserted that it was earlier, in Fuller $v$ Thorne (1533) and other Admiralty cases dating from the $16^{\text {th }}$ century; ${ }^{708}$

- First Reported Case - Inland BOE. The first BOE were foreign bills. Holt CJ stated that he remembered when actions on inland BOE first began in the English courts. This suggests the period c. 1660-70. ${ }^{709}$ Cranch proposed 1663 as the first case. ${ }^{710} \mathrm{He}$ also asserted that BOE were in general use by $1645-6$ and in existence (possibly) by $1622 ;^{711}$

- $\quad$ First Reported Case - Promissory Notes. Promissory notes (also called 'bills obligatory' or 'bills of debt') were said by Kyd to have been introduced some 30 years prior to the reign of Queen Anne

of the Italian commercial cities; and there is no doubt that its legal development took place under the influence of the Italian commercial lawyers.' See also Holden, n 375, p 1.

${ }^{699}$ Moshenskyi, n 343, p 75 'The church greatly influenced the commercial credit development.' Ibid, p 82. In respect of fairs, see Ibid, ch 2.3. See also Holdsworth, n 26, vol 8, p 129.

${ }^{700}$ Bewes, n 34, p 53 and Holden, n 375, p 2.

${ }^{701}$ Hence, Kyd, n 693 (1795 ed), p 3 'A bill of exchange...may be defined, to be an open letter of request, addressed by one person to a second, desiring him to pay a sum of money to a third, or to any other to whom that third person shall order it to be paid: or it may be payable to bearer.'(italics supplied)

${ }^{702}$ See Salzman, n 214, p 32.

7033 Ric 3 c 3 (rep 1948). It was forbidden to export without Crown licence 'gold, silver, nor other treasure nor commodity out of the said realm by letter of exchange etc.' See also 5 Ric II st 1 c 2 (1381)(prohibition on export of gold and silver); Bewes, n 34, p 55 and Holden, n 375 , p 21.

${ }^{704}$ Bewes, n 34, pp 55-6 'But letters of credit were common in England many years before and were issued by our kings for the purpose of makings payments or raising money abroad; thus, Richard I [1189-99], obtained an advance of 2,125 marks from the company of merchants of Piacenza on a letter apparently addressed to all merchants, and others were issued by king John. Payment was to be made on presentation of the letter with the acknowledgement of the receipt of the sum claimed.' See also Sanborn, n 35, pp 347-8 and Holden, n 375, p 21.

${ }^{705}$ See Holden, $\mathrm{n} 375$, ch 2 .

${ }^{706}$ For these, see generally Postan (n 692) and Holdsworth, n 26, vol 8, p 113 et seq, especially p 146, where Holdsworth asserted the more modern form of BOE was not recognised by the common law until the $16^{\text {th }}$ century. See also Rogers, $\mathrm{n} 12$, ch 3 .

${ }^{707}$ Cro Jac 6 (79 ER 6). See also Holdsworth, n 26, vol 8, p 159 (earliest reported case); Thornely, n 32, p 35; Scrutton, n 188, p 29; Holden, n $375, \mathrm{p} 31$ and Street, n 16, vol 2, p 347. See generally, Rogers, n 12, ch 3.

${ }^{708}$ See SS, vol 6, pp 38, 179-81. See also Bewes, n 34, p 56; Holden, n 375, pp 25-7; Rogers, n 12, pp 51-2 (who asserted there was little evidence to suggest the Admiralty Court had developed any special body of law concerning BOE); Thornely, n 32, p 22 (BOE, 1533) and p 26 (BOE, 1540). Cf. Baker I, n 38, p 1235 'the first recorded example of an action expressly founded on a [BOE] being an undated precedent of the 1590 s in Rastell's Entrees, and the first reported example being in 1602.' Cranch, n 16, vol 3, p 76 cited a precedent pre 1564. See also Holden, n 375, p 28 and Baker I, n 38, p 1244.

${ }^{709}$ Buller v Crips (1703) 6 Mod 29 (87 ER 793) per Holt CJ 'I remember when actions on inland bills did first begin, and there they laid a particular custom between London and Bristol; and it was an action against the acceptor, the defendant's counsel would put them to prove the custom: at which Hale, the chief justice [1654-76] who laughed and said that they had a hopeless case of it [because the common law did not need to be proved]. And in my lord North's time, it was said the custom in that case is part of the common law of England.' Kyd, n 693 (1795 ed), p 11 'inland bills cannot be supposed to have been very frequent before the reign of Charles II [1660-85].'

${ }^{710}$ Cranch, n 16, vol 3, p 83 citing Edgar v Chut (1663) 1 Keb 592 (83 ER 1130). See also Holden, n 375, p 54.

${ }^{711} \mathrm{Ibid}, \mathrm{p} 81$, inland BOE and promissory notes began to be in general use c. 1645-6 with (p 83) no distinction then being made between the same (the word 'bill' and 'note' also being interchangeable). See also Street, n 16, vol 2, pp 360, 369 and Rogers, n 12, pp 125-6. 
(1702-14). This suggests c. $1670 .{ }^{712}$ Cranch thought that it was earlier - possibly1645-6. ${ }^{713}$ Promissory notes were recognized by the courts by 1681 - including (it seems) their negotiability. ${ }^{714}$ However, Holt CJ refused to recognize their negotiability, ${ }^{715}$ a position reversed by the Promissory Notes Act $1704 .{ }^{716}$

\section{In conclusion, foreign BOE where recognized by the English courts by 1603 (or earlier) and inland BOE and} promissory notes by c. 1670. The negotiability of all of them was recognized by 1704.

\section{(b) Law Merchant in the Field of BOE?}

Until the twentieth century, the general tenor of legal writing was that the law merchant was a distinct (separate) body of law which gradually became incorporated into the common law. Rogers - in his Early History of the Law of Bills and Notes (1995) - challenged this 'incorporation' theory, one held by Holdsworth and others (see 25). He stated:

The general thesis of this book is that the traditional incorporation theory is inaccurate, at least with respect to the law of bills and notes. The judges of the English common law courts did not borrow the rules of the law of bills from sources external to the common law system. Rather, the English law of bills developed within the common law system itself, in response to developments in commercial and financial practice. ${ }^{717}$

Thus, Rogers asserted that, in the context of BOE, there was:

- no separate body of law merchant;

- no evidence that merchants shunned the common law courts; ${ }^{718}$

- evidence that the common law courts were enforcing obligations arising out of exchange transactions long before the $17^{\text {th }}$ century. ${ }^{719}$

all of which derogated against an incorporation theory. ${ }^{720}$ One would agree and add the following which seems to further substantiate this.

\section{(c) Differences between Law Merchant \& Common Law}

In respect of an asserted distinct body of law merchant with respect to BOE and promissory notes, writers have tended to concentrate on four issues, which I also do, but insert in italics when acceptance by the common law courts occurred.

\footnotetext{
${ }^{712} \mathrm{Kyd}, \mathrm{n} 693$ (1795 ed), p 18 'As commerce advanced in its progress; the multiplicity of its concerns required, in many instances, a less complicated mode of payment than by bills of exchange. A trader, whose situation and circumstances rendered credit from the merchant or manufacturer who supplied him with goods, absolutely necessary, might have so limited a connection with the commercial world at large, that he could not easily furnish his creditor with a bill of exchange on another man; but his own responsibility might be such, that his simple promise of payment, reduced to writing for the purpose of evidence, might be accepted with equal confidence as a bill on another trader: hence it may reasonably be conjectured, promissory notes were at first introduced; and that their period of introduction appears to have been about 30 years before the reign of Queen Anne.' Kyd cited Buller v Crips, see n 709.

${ }^{713}$ Cranch, n 16, vol 3, pp 80-1. See also Street, n 16, vol 2, ch 35.

${ }^{714}$ Shelden $v$ Hentley (1681) 2 Show (89 ER 860) per Jones J 'it was the custom of merchants that made that good.' See also Cranch, n 16, vol 3 , p 84 and Holden, n 375, pp 74-9.

${ }^{715}$ Clerke v Martin (1702) 2 Ld Raym 757 (92 ER 6). See also Scrutton, n 25, pp 31-3; Baker II, n 38, p 1280 and Rogers, n 12, pp 177-86.

${ }^{716}$ See n 733 .

${ }^{717}$ Rogers, n 12, p 2. Ibid, p 20 'In the standard accounts of the history of commercial law, the law merchant is usually taken to have been a body of substantive law based on mercantile custom, distinct from the common law applied in central courts. Although this view has won nearly universal acceptance among writers on commercial law, the evidence shows that it is quite inaccurate.'

${ }^{718}$ Ibid, p 20 'the usual assumption that merchants shunned the common law courts is inaccurate.'

${ }^{719}$ Ibid, p 54 'In fact, the common law courts enforced obligations arising out of exchange transactions long before the era of the so-called 'incorporation' of the law merchant in the seventeenth century.'

${ }^{720}$ Ibid, p 67 'The conventional account of the early common law actions involving [BOE] is an effort to solve a non-existent problem. The assumption has been that from medieval times merchants had been dealing with [BOE] in essentially the same fashion as merchants of the late eighteenth century, and that the mercantile courts resolved disputes arising out of these transactions by applying a fully developed law of [BOE] ...Yet so far as one can tell from the published records of court proceedings, the supposed disparity between the common law and the law merchant and the common law did not exist. The most plausible conclusion about English cases involving exchange or [BOE] before the seventeenth century is that they were handled in very much the same way regardless of which court they were in.'
} 
- Merchants. At first, BOE's were only enforced by the English courts if a merchant was involved. Thus, in Oaste $v$ Taylor (1612), a plea that the acceptor of a BOE was not a merchant was upheld. $^{721}$

- However, after a transition stage ${ }^{722}$ - by Sarsfield v Witherly (1692) ${ }^{723}$ - a merchant did not need to be involved; ${ }^{724}$ anyone could sue on a BOE. Further, as Pollexfen CJ (not Holt CJ) noted in 1689, the general population were using BOE. ${ }^{725}$ Thus, this restriction had gone by 1692 ;

- Days of Grace. At common law, a debtor was obliged to pay on the agreed date. However, a custom of merchants permitted days of grace in the case of payment under a BOE - although the number of days differed in different locations and countries, so there was no ius gentium. The London custom was 3 days grace.

- The common law courts accepted this - in respect of foreign BOE - by Tassell v Lewis (1695) ${ }^{726}$ and - in respect of inland BOE - by Coleman v Sayer (1728). ${ }^{727}$ Thus, days of grace were accepted by the common law by 1728 at the latest;

Assignability. The assignment of a chose in action (such as a debt) was not upheld at common law, though it was in equity. ${ }^{728}$ However, BOE were negotiated by merchants prior to $1654 .^{729}$ Indeed, it seems that tallies were negotiable from an early time (although it may be that the reference to 'bearer' was to an agent or representative). ${ }^{730}$ Hale (writing c 1676) stated: 'By the common law a thing in action is not assignable. Yet in cases of bills of exchange, being by the custom of merchants, they are assignable.' 731

\footnotetext{
${ }^{721}$ Cro Jac 306 (79 ER 262) (the acceptance of a BOE amounts, by the law merchant, to a promise to pay it. However, it must be stated that the drawee was a merchant at the time he accepted it). See Holden, n 375, p 32. Cf. Rogers, n 12, p 130.

${ }^{722}$ MacDonell, $\mathrm{n} 375$, $\mathrm{p}$ lxxxi 'The existence of a transition stage is indicated in the remarks made in certain judgments, that a person who drew a bill of exchange 'made himself a merchant within the custom'. For the transition, see Street, n 16, vol 2, pp 348-52; Holden, n 375, pp 32-6; Thornley, n 32, pp 35-6; Rogers, n 12, ch 6 and JH Baker \& SFC Milsom, Sources of English Legal History (Butterworths, 1986), pp 458-62. See also Baker I, n 38, p 1257 (useful procedural device, no more).

${ }^{723}$ Carth 82 (90 ER 652), p 82. The BOE was drawn by a non-merchant but the court upheld it "upon consideration had of the inconveniences which might ensue, and the suspicion which might increase amongst foreign merchants, upon [BOE] if persons who took upon themselves to draw such bills should not be liable to the payment thereof; they all agreed that the judgment should be reversed.' See also Witherley $v$ Sarsfeild (1689) 1 Show 125 (89 ER 491) at p 127 per Holt CJ 'this drawing a bill must surely make him a trader for that purpose.' As to whether this was Holt CJ or Pollexfen, see Baker \& Milsom, n 722, p 461 'The report says Holt, who was CJKB. Pollexfen CJCP who gave judgment in the Exchequer Chamber: cf. Comb 152 (citing Sarsfield v Witherley].' Williams v Williams (1692) Carth 269 (90 ER 759) at p 270 'this custom of merchants concerning bills of exchange is part of the common law, of which the judges will take notice ex officio as it was resolved in the case of Carter v Dowrish [see n 738] and therefore 'tis needless to set forth the custom specially in the declaration.' Kyd, n 693 (1795 ed), p 28 'it has since been decided that any person capable of binding himself by a contract, may draw or accept a bill of exchange, or be in any way engaged in the negotiation of it, and shall be considered as a merchant for that purpose; and that it is not necessary in a declaration on a bill, to aver, that the defendant is a merchant.' See also Baker I, n 38, p 1257.

${ }^{724}$ Rogers, n 12, p 141 'By the end of the seventeenth century, any pretence that the custom of merchants was to be treated as special custom had been dropped, for the judges had ruled that the custom need not even be set out in the pleadings.'

${ }^{725}$ Witherley $v$ Sarsfield (see n 723) per Holt CJ at $\mathrm{p} 127$ per Holt CJ 'we all have bills directed to us, or payable to us.' Bromwich v Loyd (1697) 2 Lut 1582 (125ER 870) at p 1585 per Treby CJ 'Bills of exchange at first extended only to merchant strangers trafficking with English merchants; and afterwards to inland bills between merchants trafficking the one with the other in England; and afterwards to all traders, and then to all persons whether traders or not; and there was then no need to allege any custom of merchants.' (see Scrutton, n 25 , p 29 for the translation). See also Holdsworth, n 26, vol 8, p 169 and Street, n 16, vol 2, pp 351-2.

7261 L Raym 743 (91 ER 1397) per Holt CJ. See also Thornley, n 32, p 36.

7271 Barn 303 (94 ER 206). For promissory notes, see Brown v Harraden (1791) 4 TR 148 (100 ER 943)(3 days grace). See also Holden, n 375, pp 159-60 and Kyd ( $3^{\text {rd }}$ ed, 1795), n 693, pp 122-5.

${ }^{728}$ The reason why it was not upheld was expressed by Coke, $\mathrm{n} 16$, vol 1, 214 'for avoiding of maintenance, suppression of right, and stirring up of suits'. Blackstone, n 186, vol 2, p 442 'no chose in action could be assigned or granted over, because it was thought to be a great encouragement to litigiousness, if a man were allowed to make over to a stranger his right of going to law.' See also Rogers, $\mathrm{n} 12, \mathrm{p} 172$. By the Judicature Act 1873, courts applied common law and equity.

${ }^{729}$ Rogers, n 12, p 170 thought that the practice of indorsement did not become common until after 1600. Street, n 16, vol 2, pp 359-60 noted that Marius gave examples of indorsed BOE dated 1654. See also Holden, n 375, pp 42-52.

${ }^{730}$ See n 214.

${ }^{731}$ Pritchard, n 218, p 55 (M Hale, Treatise on Admiralty c.1676).
} 
- The common law courts seem to have accepted the assignment of BOE without much ado; ${ }^{732}$ Further, the Promissory Notes Act 1704 provided that all 'notes in writing...made and signed by any person ... whereby [they] promise to pay to any other person ...or their order, or unto bearer, any sum mentioned in such note shall be assignable or endorsable over, in the same manner as inland bills of exchange...according to the custom of merchants.' 733

- Consideration. At common law, a written document could not be pleaded against a person unless by way of deed (i.e. in writing, sealed and delivered). However, sealed tallies had long been upheld by treating them - by way of a legal fiction - the same as a bond (obligation). ${ }^{734}$

- By 1689, Holt CJ was prepared to presume consideration in respect of BOE if it stated it was for 'value received'. ${ }^{735}$ By 1714, it was held such a presumption existed without such words. ${ }^{736}$

In conclusion: (a) any difference between the law merchant and the common law in respect of BOE and promissory notes being only capable of being sued upon if brought by a 'merchant' ended by 1692 at the latest; (b) 3 days of grace was part of the common law (that is, applied generally) by 1728 at the latest; (c) the assignability of BOE and promissory notes was accepted by the common law and legislation by 1704 at the latest; and (d) a presumption of consideration in the case of BOE and promissory notes was upheld by 1689.

\section{(d) Law Merchant part of the Common Law}

In c.1280, the author of Lex Mercatoria had made it clear that the law merchant was part of the common law (see 8) and there is no evidence the courts adopted a different approach subsequent to this. Thus, in Van Heath $v$ Turner (1621), Hobart CJ stated:

the customs of merchants is part of the common law of this kingdom, of which the judges ought to take notice: and if any doubt arise to them about their custom they may send for the merchants to know their custom, as they may send for the civilians to know their law.

A similar sentiment was expressed in Carter $v$ Downish (1688). ${ }^{738}$ Further, there is nothing to suggest, in this period, that the courts were doing other than what they were doing with customs generally. If well established and reasonable, they were upheld, the custom being proved to the court by means of a jury confirming the same. The speed of acceptance by the common law courts may also be noted:

- $\quad$ Texts on BOE. Texts on BOE's and promissory notes from the $17^{\text {th }}$ and $18^{\text {th }}$ centuries ${ }^{739}$ indicate how quickly business practices in respect of them were adopted into legislation ${ }^{740}$ or the courts recognising them. Holden thought most of this was completed by $1710 ;^{741}$

\footnotetext{
${ }^{732}$ Rogers, $\mathrm{n} 12, \mathrm{p} 171$ 'Contrary to the usual view that the main theme of the early history of the law of bills was the struggle against the common law principle that choses in action are not assignable, the practice of transferring bills seems to have been accommodated by the common law courts with relatively little difficulty.'

${ }^{733} 3$ \& 4 Anne $\mathrm{c} 9$. The preamble to the Act stated: 'Whereas it hath been held, that [promissory notes] are not assignable or indorsable over, within the custom of merchants, to any other person... therefore, to the intent to encourage trade and commerce... be it enacted.' See also Holden, n 375, pp 79-80 (and App C); Holdsworth, n 26, vol 8, pp 170-7; Cranch, n 16, vol 3, pp 72-94 and Rogers, n 12, pp 177-86. Thornely, n 32, p 36 'Bank notes received recognition in 1758 [Miller v Race (1758) 1 Burr 452 (97 ER 398) where Mansfield CJ treated them as equivalent to money] cheques and drafts in 1764 [Grant $v$ Vaughan (1764) 3 Burr 1516 (97 ER 957)] and exchequer bills in 1820 [Wookey $v$ Pole (1821 4 B \& Ald 1 (106 ER 839)].' See also Rogers, n 12, pp 177 \& 187 and Holden, n 375, p 87-98 \& pp 114-7.

${ }^{734}$ See $\mathrm{n} 214$.

${ }^{735}$ Cramlington $v$ Evans (1689) 1 Show 5 (89 ER 410) per Holt CJ 'if the drawer mention it 'for value received', then he is chargeable at common law; but if no such mention, then you must come upon the custom of merchants only.'

${ }^{736}$ Josceline v Lassere (1714) Fort 281 (92 ER 853) per Parker CJ at $\mathrm{p} 282$ 'There is no necessity in a bill of exchange of saying value receiv'd'. See also Holden, n 375, pp 63, 102-3 \& 168. Also, Bills of Exchange Act 1882, s 30(1).

${ }^{737}$ Winch 24 (124 ER 20) at p 24. See also Holdsworth, n 26, vol 5, p 146. Peirson v Pounteys (1609) Yelv 135 (80 ER 91), at p 136 'the judges ought to take notice of that which is used amongst merchants for the maintenance of traffic [business].'

${ }^{738}$ Carth 83 (90 ER 652). The Court of Exchequer Chamber stated that 'they ought ex officio to take notice of the law of merchants, because "tis part of the law of the land; and especially they ought to take notice of this custom concerning bills of exchange, because "tis the most general amongst all their customs.' See also Rogers, n 12, p 143. Kyd, n 693 (1795 ed), p 6 'The custom of merchants, which makes part of the law of the land.'

${ }^{739}$ See n 693 .

${ }^{740}$ See the regulation of inland BOE in the Payment of Bills Act 1698 (9 Wm III, c 17, rep 1882) and the negotiability of promissory notes in the Promissory Notes Act 1704 (3 \& 4 Anne, c 9, rep 1882). See also Holden, n 375, pp 54-5.
} 
- Position by 1795. Kyd, who wrote a major text on BOE and promissory notes in 1795 , referred to the custom of merchants in the context of BOE in respect of: (a) usance; ${ }^{742}$ and (b) days of grace. ${ }^{743}$ However, this was only with respect to different practices in other countries. Kyd also noted that differences between inland, and foreign, BOE ${ }^{744}$ had gone. So too, with regard to promissory notes vis-à-vis their assignability. ${ }^{745}$ Finally, Kyd noted that a married women could not be a payee (or indorsee) of a BOE since she could not sue - not possessing property in a capacity distinct from her husband. ${ }^{746}$ However, this applied generally and not just to the wives of merchants. Therefore, it cannot be said to be a custom of merchants. Thus, Kyd's treatise lends support to the contention of Holden.

Further, the fact that a custom of merchants was involved - as opposed to any other custom - did not, even from an early time, with regard to BOE, influence the court. Baker noted, with reference to mid- $16^{\text {th }}$ century cases on BOE with respect to the action of assumpsit in the King's Bench, ${ }^{747}$ that:

there is no hint that the mercantile character of the transaction in itself made any difference to the result. There was no commission in these cases to proceed according to the law merchant. The law merchant was not even mentioned in the declarations...Apart from occasional use of the phrase secundum usum mercatorum, which falls far short of a custom, in none of the sixteenth-century cases so far discovered was there any attempt to lay the custom of merchants in the declaration. ${ }^{748}$

The introduction of references in declarations to the law merchant from about 1600 does not, therefore, indicate that this comprised an incorporation of law merchant into the common law. ${ }^{749}$

\section{(e) Conclusion}

In conclusion, there is nothing to suggest that the law on BOE and promissory notes - even in an early time - was distinct from the common law. That is, there was no question of the 'tail wagging the dog' with the courts having to accepted various customs of merchants as law. ${ }^{750}$ Instead, the courts (as with all local customs) were prepared to accept them and, thereby, make them the law of the land if they were well enough established and reasonable. Further, the example of Holt CJ ${ }^{751}$ is a clear indication that the courts would not be pushed on such matters. They were in control of this process and not merchants. Finally, was the law on BOE's and promissory notes part of a ius gentium? It is asserted there is no evidence of this. As Rogers pointed out, even early English texts on commercial law such as Malynes, Marius and Molloy (see 19) were rarely referred to in cases. ${ }^{752}$ Further, a

\footnotetext{
${ }^{741}$ Holden, n 375, p 30 'By the end of the seventeenth century the law merchant was practically absorbed into the legal system of the country'. Coquillete, n 13, p 273 'Holden has demonstrated that a full ninety percent of the law merchant to be developed by the common law was in place when Holt retired in 1710.' See also Street, n 16, vol 2, p 334.

${ }^{742} \mathrm{Kyd}, \mathrm{n} 693$ (1795 ed), p 4 'Usance is the time of one, two, or three months after the date of the bill, according to the custom of the places between which the exchanges run...Usance between London and any part of France, is thirty days after date.... Between London and Spain and Portugal, two calendar months..etc.' See also Bewes, n 34, p 53 (who also noted 'Bills drawn at usance (now obsolete)...'

${ }^{743}$ Ibid, p 9 'A custom has obtained among merchants, that a person to whom a bill is addressed, shall be allowed a little time for payment, beyond the grace mentioned in the bill, called days of grace. But the number of these days varies, according to the custom of different places. Great Britain, Ireland, Bergamo, and Vienna, three days. Frankfurt, out of time of the fair, four days...etc.'

${ }^{744}$ Ibid, p 12 'what was the law and custom of merchants with respect to the one, is now, in most respects, the established law of the country with respect to the other'. Kyd referred to legislation (see n 740) which adopted the practice of one to be the same as the other.

${ }^{745}$ They were, at first, held not be indorsable or assignable within the custom of merchants. An Act of 1705 (3 \& 4 Ann c 9) made them so, by putting them on the same footing as inland bills of exchange.

${ }^{746}$ Kyd, n 693 (1795 ed), p 30. See also Law Reform (Married Women and Tortfeasors) Act 1935.

${ }^{747}$ Dolphyn v Barne (1540) and Towll v Hawkyns (1549), see Baker I, n 38, pp 1247-8.

${ }^{748}$ Baker I, n 38, p 1248. Ibid, p 1249 'It is true that no one has yet made a thorough search of the King's Bench rolls between 1550 and 1600. But enough has come to light, both from random searches and from a study of books of entries, to show that the [BOE] was received into the common law without express reliance on 'law merchant'.'

${ }^{749}$ See also Rogers, n 12, p 132 et seq. One would agree that it was procedural and not reflecting a major change in approach.

${ }^{750}$ Thus, Holt CJ rejected the negotiability of promissory notes, even though the practice was widespread. See n 715 .

${ }^{751}$ See $\mathrm{n} 715$. One has considerable sympathy for Holt. It is a major thing for a judge to accept what was a business practice practice in London as the law of the land. Thus, due consideration and seeing how that practice was developing would seem a counsel of wisdom. Mansfield CJ was also prepared to reject London customs, if unsure, see ns 918 \& 919. See also, Baker I, n 38, p 1237 and Baker II, n 38, p 1280.

${ }^{752}$ Rogers, $\mathrm{n} \mathrm{12,} \mathrm{p} 153$ 'In fact, there are relatively few references to books on the law merchant in the cases on bills...Yet by [1703], the common law courts had already worked out most of the basic principles of the law of bills of exchange, and the reports of the decisions of the common law courts contained nearly a 100 cases on bills. In the eighteenth century, one finds somewhat more frequent references to such works, but the number of instances is still very small in comparison to the volume of litigation.' See also Coquillette, n 13, pp 248 \& 274 (few references, mainly in counsel's argument).
} 
word search in the English Reports (1220-1873) of well known Continental texts such as Straacha (1553) ${ }^{753}$ and Scaccia (1619) ${ }^{754}$ indicates minimal references. ${ }^{755}$ This is unsurprising since, even a glance at these works, shows that they would hardly be something that English common lawyers (or judges) would see as of much relevance, with their copious references to the Digest and to ecclesiastical lawyers. ${ }^{756}$

Thus, there is no evidence of the English law merchant being part of a ius gentium, vis-à-vis BOE or promissory notes. ${ }^{757}$ Rather, the English courts adopted, where suitable, local custom, especially that of London. This may be readily seen from the texts. ${ }^{758}$

In conclusion, there is no evidence that customs of merchants in England in respect of BOE and promissory notes comprised a distinct law (or part of a ius gentium). Further, by 1710, such had become part of the common law, to a very great extent.

\section{MUTATION OF 'LAW MERCHANT' IN THE $17^{\text {th }}$ CENTURY}

By the early $17^{\text {th }}$ century all the benefits accorded to merchants which Bracton, Britton, the author of Lex Mercatoria and Fleta referred to in the period 1240-90 (as well as piepowder and local maritime courts) were either obsolete or they were available to subjects in general and not just to merchants. Given this, one would have expected the concept of 'law merchant' to have faded away. However, it was preserved by various writers asserting that the law merchant was part of a universal law (ius gentium) - one which included a universal mercantile law. Yet, while this sounded good and it reflected the 'spirit of the times', ${ }^{759}$ there was no evidence of a universal mercantile law. Further, those who asserted so vociferously a ius gentium were partisan. As will be seen:

○ Davies (writing in 1614-21) was seeking to uphold the Crown's prerogative to tax and his assertion of a ius gentium was tailored towards this end;

- Malynes (1622) and Molloy (1676) were merchants keen to emphasise that commerce benefitted the country. Assertion of a ius gentium helped put pressure on the courts to respect business practices and accord merchants the respect they felt they deserved;

- Zouch (1656) and Godolphin (1661) were judges of the HCA, anxious to defend its diminishing jurisdiction. Assertion of a ius gentium, and their copious references to foreign law and foreign writers, bolstered their case that the HCA should be retained as a court.

Such people 'regarded merchants as a class apart, subject to a separate law. ${ }^{760}$ However, it is asserted that this

\footnotetext{
${ }^{753}$ B Straccha (or Stracca), Tractatus de Mercatura, seu Mercatore (Venice, 1553). Piergiovanni I, n 41, chapter by C Donahue, Benvenuto Stracca's De Mercatura: Was there a Lex Mercatoria in Sixteenth-Century Italy?, p109 'Does Stracca provide any evidence about the existence of a lex mercatoria in the sense of a body of customary law like that of the Llibre del Consolat de mar? The answer must be a rather emphatic 'no'. Ibid, p 110 'He [Stracca] never, so far as we can tell, uses the term lex mercatoria or ius mercatorum....So far as we can tell, the term meant nothing to him.'

${ }^{754}$ S Scaccia, Tractatus Commerciis et Cambio (Rome, 1618). Baker II, n 38, p 1269 also cited A Merenda, De Cambio Nundinati (Pavia, 1645).

755 The English Reports (1225) contain, it is said, some 100,000 cases (see also $\mathrm{n} 687$ ). Therefore, such a search would give a reliable indication as to the extent to which foreign writers on commercial law were cited, or treated as persuasive, by the courts. Rogers, $\mathrm{n} 12$, pp 219-20 'In all of the bills cases decided during his tenure, Mansfield never seems to have cited any continental sources on mercantile law nor any of the English books on mercantile affairs derived from continental sources... By the late eighteenth century, the relevant sources of authority on the law of bills were the hundreds of decisions of the English courts spanning a period of nearly two centuries and the emerging body of native English treatises in which the cases were digested and discussed.' One would agree.

${ }^{756}$ Baker I, n 38, p 1261 'no reliance was placed in this period on learned treaties of the law merchant or of mercantile practice or of the laws of nature, and ...no calls were made on the civil lawyers for their evidence or assistance.' Rogers, n 12, p 164 'while it is certainly true that English lawyers in the seventeenth and eighteenth centuries sometimes described the law merchant as ius gentium, there is little evidence to suggest that the substantive rules of the law of bills and notes were drawn from the continental literature on mercantile law or the law of bills. Rather, the English judges and lawyers necessarily built the law of bills from native materials.'

${ }^{757}$ Rogers, n 12, p 164 'When one considers carefully the task that the English judges faced in the seventeenth and eighteenth centuries, it becomes apparent that they could not have lifted a pre-existing body of law from some other source and dropped it into the common law to serve as the English law of bills. The task that they faced was not to engraft an addition on to English law but to rework the common law system itself to accommodate the major changes in economic conditions and commercial practice that were occurring in the seventeenth and eighteenth centuries.'

758 See n 693

${ }^{759}$ From the Middle Ages onwards, in fits and starts, there were theological, philosophical and legal texts and theories emphasising the universality of nature and of law (especially canon law). The 17th century was also when economic analysis of merchants, and their capacity for wealth creation, began. See JR McCulloch (ed), Early English Tracts on Commerce (Cambridge UP, 1954).

${ }^{760}$ MacDonell,.n 375, p lxxxi.
} 
was simply untrue, in reality. Their writings are now considered.

\section{(a) Davies (c. 1614-21)}

Sir John Davies, who was Attorney-General in Ireland to James I (1603-25), wrote a tract on Impositions between 1614-21. One which was not published until $1656 .{ }^{761}$ It was partisan affair, dedicated to James I, and clearly written to support the Crown's asserted prerogative to tax without Parliament's consent as well as to create monopolies. ${ }^{762}$ In it, Davies asserted that the law merchant was part of a ius gentium. He stated:

The law merchant, as it is a part of the law of nature and nations, ${ }^{763}$ is universal and one and the same in all countries in the world; for as Cicero says of the law of nations, non erit alia lex Romae, alia Athenis, alia nunc, alia posthac, sed et omnes gentes et omni tempore una lex eademque; perpetua continebit, etc. ${ }^{764}$ [There will not be one such law in Rome and another in Athens, one now and another in the future, but all peoples at all times will be embraced by a single and eternal and unchangeable law]. So we may say of the law merchant, there is not one law in England, another in France, another in Spain, another in Germany, but the same rules of reason and the like proceedings of the law merchant are observed in every nation. ${ }^{765}$ (wording divided)

Davies' quotation from Cicero was not wholly accurate. ${ }^{766}$ It was also dis-ingenuous since it is clear that Cicero was not asserting that the law merchant was part of the ius gentium. ${ }^{767}$ That is the assertion of Davies - who also argued that the law merchant was the 'principal' branch of the law of nations. ${ }^{768}$ However, in his tract, Davies provided no evidence that the commercial law in England, France, Spain or Germany etc. was the same, both at the time he was writing or before. Davies went on to enumerate various differences between the common law and the law merchant ${ }^{769}$ as part of his thesis that the latter was distinct. Thus, he cited differences:

(a) partnership - a merchant had a duty to account; ${ }^{770}$

(b) partnership - the rule of survivorship applied to a merchant; ${ }^{771}$

\footnotetext{
${ }^{761}$ Davies, $\mathrm{n} 18$.

${ }^{762}$ Noted by Holdsworth, n 26, vol 1, p 572. Rogers, n 12, pp 156-8 described Davies' tract as 'a polemic produced by a loyal supporter of James I in favour of royal prerogative to levy impositions.' One would agree and it was in tenor with others. See, e.g., J Cowell, in his law dictionary, The Interpreter (1607)(subsidie) 'Some hold opinion, that this subsidy is granted by the subject to the Prince, in recompense or consideration, that whereas the Prince of his absolute power, might make laws of himself, he does of favour admit the consent of his subjects therein, that all things in their own confession may be done with the greater indifferency.'(italics). See also Coquillette, n 13, p 86.

${ }^{763}$ Davies, n 18, p 4 'Jus gentium, or the general law of nations is of equal force in all kingdoms, for all kingdoms had their beginning by the law of nations.' Ibid, p 7 'the law of nations...which is nothing else but that which common reason has established among all men for the common good of all men, and which all nations have received and embraced for their mutual benefit and commodity.'

${ }^{764}$ Ibid, p 10 'both the common law and statute law of England do take notice of the law merchant, and do leave the causes of merchants to be decided by the rules of that law.'

${ }^{765}$ Ibid, pp 17-8. Also, p 10 'Mercatura vel societas mercatorum est magna republica (says Ulpian) and therefore that Commonwealth of merchants has always had a peculiar and proper law to rule and govern it; this law is called the law merchant, whereof the laws of all nations do take special knowledge..' Ibid, p $27^{`}$ the general law of nations, which is and ought to be law in all kingdoms, and the law merchant is also a branch of that law, and likewise the imperial or Roman law have been ever admitted, had, received, by the kings and people of England, in causes concerning merchants and merchandizes...' $R v$ Cusacke (1619) 2 Rolle Rep 113 (81 ER 694) at pp 113-4 Davies (the king's sarjeant) arguendo, 'the law merchant is the law of nations, and the mercatura or fellowship of merchants in every realm is a great commonwealth (magna republica), as Ulpian says, for of this commonwealth all nations participate.' Cited by Baker I, n 38, p 1255 \& Baker II, n 38 , p 1265.

${ }^{766}$ Noted in E McKendrick, Goode on Commercial Law (4 ${ }^{\text {th }}$ ed, Penguin, 2010), p 1355.

${ }^{767}$ See N Rudd (trans), Cicero, De Republica (OUP, 1998), 3.22.33 'law in the proper sense is right reason in harmony with nature. It is spread through the whole human community, unchanging and eternal, calling people to their duty by its commands and deterring them from wrongdoing by its prohibitions. When it addresses a good man, its commands and prohibitions are never in vain; but those same commands and prohibitions have no effect on the wicked. This law cannot be countermanded, nor can it be in any way amended, nor can it be totally rescinded. We cannot be exempted from this law by any decree of the Senate or the people; nor do we need anyone else to expound or explain it. There will not be one such law in Rome and another in Athens, one now and another in the future, but all peoples at all times will be embraced by a single and eternal and unchangeable law; and there will be, as it were, one lord and master of us all - the god who is the author, proposer, and interpreter of that law.' (italics supplied)

${ }^{768}$ Davies, n 18, p 146 'the law merchant, which is a principal branch of the laws of nations...'

${ }^{769}$ Ibid, p 15 'we see how merchandizes do differ from other goods and chattels in the eye of the law, and how the law merchant does differ from the common law of England, and how the common law does admit and allow thereof.' Ibid, p 10 'both the common law and statute law of England do take notice of the law merchant, and do leave the causes of merchants to be decided by the rules of that law.' Cf. Holdsworth, n 26, vol 1, p 570 (he thought Davies was asserting the law merchant only applied to foreign trade).

${ }^{770}$ Ibid, p 12 'If two merchants be joint owners, or partners in merchandizes, which they have acquired by a joint contract, in this case the one shall have an action of account against the other ...yet by the rule of the common law, if two men be jointly possessed of other goods which are not merchandizes, the one shall not call the other to account for the same.'
} 
(c) letters of reprisal were available to merchants; ${ }^{772}$

(d) wager of law on a debt in a simple contract was unavailable to a merchant; ${ }^{.73}$

(e) a suit not by way of deed on a BOE etc. could be brought by a merchant; ${ }^{774}$

(f) Statute of Merchants 1285 and Statute of the Staple 1353 applied to merchants; ${ }^{775}$

(g) the stolen goods of a merchant were not forfeit to the Crown (waif). ${ }^{776}$

However, these matters hardly comprised a ius gentium prevailing in all nations. Further, some of them did not apply just to merchants and Davies must have known this. Others had been recognized by the common law, or soon were to be and, thus, were no longer privileges just of merchants. Thus:

- Letters of Reprisal \& Recognizances. In the cases of (c) ${ }^{777}$ and (f) ${ }^{778}$ citation was inappropriate since they not only applied to merchants; they could be availed of by any subject. Further, (c) would have been rare when Davies wrote. By then such letters were, generally, only given to privateers, ${ }^{779}$

- $\quad$ Partnership. In the case (a), the Statute of Westminster 1285 gave executors the right to have an action for account ${ }^{780}$ and the common law later recognized the right of the merchants to this. ${ }^{781}$ The action was, later, extended to all partners. ${ }^{782}$ In the case of (b), the common law had accepted this by the time

\footnotetext{
${ }^{771}$ Ibid. 'if two merchants have a joint interest in merchandizes, if the one die the survivor shall not have all, but the executor of the party deceased, shall by the law merchant call the survivor to an account for the moiety... whereas if there be two joints [joint owners] of other goods which are not merchandizes, the survivor shall have all, per jus accrescendi, even by the rule of the common law.' Davies may have taken this from Hamond v Jethro (1611) 2 Brown 99 (123 ER 836).

${ }^{772}$ Ibid, pp 13-4 'if an English merchant be spoiled of his merchandizes upon the seas or beyond the sea, by the subject of another king, [he has] a writ of reprisal against all the subjects of that nation.' Letters of reprisal were also called letters of marque and letters of marque and reprisal, see GS McBain, Abolishing Obsolete Crown Prerogatives relating to the Military (2011) Nottingham LJ, vol 20, pp 20-3. See

also MacDonell, n 375, p lxxviii and Sanborn, n 35, pp 317-9, 354

${ }^{773}$ Ibid, pp 12-3 'in an action for debt, upon a simple contract... without deed in writing, the defendant by the common law may wage his law' but a merchant could not.' Davies cited a case in 1328. See also Baker I, n 38, p 1239, n 28.

${ }^{774}$ Ibid, p 15 'in a suit at the common law no man's writing can be pleaded against him as his act and deed, unless the same be sealed and delivered; but in a suit between merchants, bills of lading, bills of exchange, being but tickets without seals, letters of advice and credences, policies of assurance, assignations of debt, all which are of no force at the common law, are of good credit and force by the law merchant.'

775 Ibid, p 16.

${ }^{776}$ Ibid, p 11 'if the merchandises of a...merchant stranger [alien merchant], be stolen and waved [waived] by the felon, the king himself shall not take those merchandizes as waifs, though in that case the goods of another person were lost [to the Crown] by the common law of England.' Davies, likely, took this (although he failed to so state) from the Carrier's Case (1485), see text and M Hemmant, Select Cases in the Exchequer Chamber before all the Justices of England (1461-1509), SS, vol 64, p 34.

${ }^{777}$ Letters of marque and reprisal could be issued to anyone (qua privateers) as well as to merchants. Indeed, it was principally to the latter that they were issued from Elizabethan times onwards, e.g. Pritchard, n 218, p 137 (Fleetwood, Treatise on Admiralty Jurisdiction c.1568) 'Any of the Queens Majesties subjects being damnified [i.e. suffering loss] by any foreign prince's subjects after league and truce taken....must sue first for letters of request and afterwards for letters of mark [marque]...' (italics supplied).

${ }^{778}$ See 16.

${ }^{779}$ Reprisals between merchants were abolished by 3 Edw 1 c 23 (1275). Letters of marque and reprisal ended in practice by 1815 . Further, the Declaration of Paris respecting Maritime Law of 16 April 1856 to which Britain was a signatory, renounced privateering an essential aspect of which was the issuing of such letters. See also GS McBain, Abolishing Obsolete Crown Prerogatives relating to the Military (2011) Nottingham LJ, vol 20, pp 20-3 and Holdsworth, n 26, vol 5, p 74.

${ }^{780}$ Coke, n 16, vol 2, p 403 'By the common law executors should not have an action of account for an account to be made to the testator, because the account rested in privity: for remedy whereof this act was made; but per legem mercatoriam an action of account did lie for executors.' Statute of Westminster 1285, c 23 'Executors from henceforth shall have a writ of accompt, and the same action and process in the same writ as the testator might have had if he had lived.' Baker II, n 38, p 1274 'there was no reason why the common law could not itself recognise special rules of law applying to merchants, as in the case of the duty to account between partners, which was enforceable by a special form of action of account.' This form of act did not just apply to merchants, see e.g. A Fitzherbert, The New Natura Brevium $\left(6^{\text {th }}\right.$ ed, 1817), pp257-62 (writ of account)

${ }^{781}$ Coke, n 16, vol 1, 182a (s 282) 'an exception is to be made of two joint merchants: for the wares, merchandizes, debts or duties, that they have as joint merchants or partners, shall not survive, but shall go to the executors of him who deceases; and this is per legem mercatoriam, which ... is part of the laws of this realm, for the advancement and continuance of commerce and trade, which is pro bono publico...'. Pritchard, n 218, p 55 (Hale, Treatise on Admiralty c 1676) 'by the common law of England one joint proprietor cannot have an account against another, and [survivorship] carries all. But by the custom of merchants it is otherwise; and the common law being assured of this custom, allows it'. DM Walker, The Oxford Companion to Law (Clarendon Press, Oxford, 1980)(account, action of ) 'At common law in England an action lay against a receiver or bailiff, or by one merchant against another in respect of dealings between them in their mercantile capacities, for not rendering a proper account of profits.'

${ }^{782}$ See $\mathrm{n} 887$ and the Partnership Act 1890, s 28.
} 
Davies was writing, as Coke (and, later, Hale) noted. ${ }^{783}$ The rule of survivorship was, later, to be treated as a rule of equity; ${ }^{.74}$

- Wager of Law \& Suits not on Deeds. In the case of (d), wager of law would have been uncommon when Davies was writing ${ }^{785}$ and St Germain in his Doctor and Student (1528) made no reference to such an exception. ${ }^{786}$ In the case of (e), by 1692, BOE were upheld at common law in the case of non-merchants. ${ }^{787}$ Further, bills of lading and insurance policies were not limited to merchants (see 20);

- Exception to Waif. In the case of (f), the Crown could not seize stolen foreign merchants' goods by way of waif. However, this exception was due to the Crown's duty (covenant) pursuant to Magna Carta 1215, chapter 41 (see 6). In other words, it was a benefit accorded by statute, not the 'law merchant' as such. 788

Davies also referred to the Carrier's Case (1473), a Star Chamber case, which considered whether it was felony when a carrier broke bulk and converted certain bales of woad (dye) belonging to a foreign merchant to his own use. ${ }^{789}$ In it, the Lord Chancellor (Robert Stillington, a cleric and civilian) stated:

This suit is taken by an alien merchant who has come here under a safe conduct: he is not bound to sue according to the law of the land to await trial by twelve men and other formalities of the law of the land, but he ought to sue here. And in the Chancery it shall be determined in accordance with the law of nature, and, for the speeding of merchants, there should be suing there from hour to hour and day to day. ${ }^{790}$

And he said further that merchants shall not be bound by our statutes where the statutes are introductive of a new law but only where they are explanatory of an old law of nature. And since they have come into the kingdom, the king for this reason has jurisdiction over them to put them to stand at right etc. But this shall be according to the law of nature [legem nature] which by some is called the law merchant, which is law universal throughout the world.

His latter observation is puzzling. It was not relevant to the case. Further, one suspects that Ulpian would have referred to the ius gentium and not to the ius naturale. ${ }^{792}$ More particularly, like the wide observations of Davies, it was not based on fact. There was no evidence of such a universal law in 1473 (indeed, Stillington, in 1473, would have had no idea how big the world was). Finally, the context of the case does not suggest that Stillington was treating the law merchant as distinct from the common law. Rather, he was dealing with a procedural issue whether the carrier should be arraigned on an indictment for felony found by a grand jury. ${ }^{793}$

In conclusion, the assertion by Davies that the English law merchant was part of a universal law, was fiction. $^{794}$

\section{(b) Malynes (1622)}

\footnotetext{
783 See n 781.

${ }^{784}$ Lyster v Dolland (1792) 1 Ves Jr p 434 (30 ER 422) at p 434, per Lord Thurlow. See also Noy, n 249, pp 63-4 and Street, n 16 , vol 2, p 334.

${ }^{785}$ Wager of law was abolished in 1833 but was in decline in the $16^{\text {th }}$ and $17^{\text {th }}$ centuries (it was last asserted in 1824). Blackstone, $\mathrm{n} 186$, vol 3 , p 348 described it (in 1768) as 'quite out of use, being avoided by the mode of bringing the action.'

${ }^{786}$ See $\mathrm{n} 369$, p 61 'in an action of debt upon a contract the deff [defendant] may wage his law that he owes nothing, even though there be witnesses of the contract.

787 See ns $723 \& 724$.

788 See Hemmant, n 776, p 34. Blackstone added (much later) another rationale (without referring to Magna Carta), n 186, vol 1, p 287 'The goods of a foreign merchant, although stolen and thrown away in flight, shall never be waifs: the reason whereof may be, not only for the encouragement of trade, but also because there is no wilful default in the foreign merchant's not pursuing the thief, he being generally a stranger to our laws, our usages, and our language.' See also GS McBain, Abolishing some more Obsolete Crown Prerogatives (2011) Liverpool LR, vol 32, pp 77-8.

${ }^{789}$ Davies, n 18, pp 10 \& 18. YB 13 Edw IV pl 5, fo 9a-10b. Seipp no 1473.005 (Star Chamber, Exchequer). See also Senior, n 520, p 23; Holdsworth, n 26, vol 9, p 95 and Baker I, n 38, p 1238.

${ }^{790}$ One wonders whether the Lord Chancellor was referring to the Carta Mercatoria (1303), see 12.

${ }^{791}$ Hemmant, $\mathrm{n}$ 776, p 32. See also discussion at $\mathrm{p}$ xxx (judges of the Exchequer Chamber held that the action of the carrier was felony).

792 Digest, n 642, vol 1, bk 1.1. Ulpian defined ius gentium as 'the law of nations, is that which all human peoples observe. That it is not co-extensive with natural law can be grasped easily, since the latter is common to all animals whereas ius gentium is common only to human beings among themselves.' He defined ius naturale as 'that which nature has taught to all animals; for it is not a law specific to mankind but is common to all animals.' See also Bk 1.9, citing Gaius, Institutes 'ius gentium ... the law which all nations observe.'

793 See Baker I, n 38 pp 1240-1 \& Baker II, n 38, p 1273.

${ }^{794}$ Coke CJ, his contemporary, was firmly of the opinion that the law merchant was part of English law, as was Hale CJ, see $\mathrm{n} 805$.
} 
Malynes, a merchant, in his Lex Mercatoria (1622) ${ }^{795}$ which is said (incorrectly) to be the first English text on commercial law, ${ }^{796}$ also supported the idea of the law merchant being part of a ius gentium. He stated:

I have entitled the book according to the ancient name of lex mercatoria, and not jus mercatorum; because it is a customary law, approved by the authority of all kingdoms and commonwealths, and not a law established by the sovereignty of any prince, either in the first foundations, or by continuance of time. ${ }^{797}$ [also] the law merchant has always been found semper eadem; that is, constant and permanent, without abrogation, according to the most ancient customs, concurring with the law of nations in all countreys. $^{798}$

However, Malynes was not a lawyer but a merchant ${ }^{799}$ and - despite seeking to trace the historical roots of the law merchant ${ }^{800}$ - he provided no legal evidence to support his claim that the law merchant was 'constant and permanent' or part of a unified customary law which was approved by the authority of all kingdoms and commonwealths, ${ }^{801}$

- Indeed, reference in his text to differing standards of measurement in England and aboard, as well as to different practices in respect of purchase and sale, revealed the considerable diversity of foreign laws, inter se;

- This was something also evidenced in a widely read text published some 16 years after Malynes wrote Roberts, Merchant's Map of Commerce (1638) - which also indicated the lack of uniformity between countries in terms of weights, measures, rates of exchange etc. ${ }^{802}$

It may be that Malynes was influenced by the definition of the law merchant in the (civilian) Cowell's law dictionary of $1607,{ }^{803}$ which definition was subsequently repeated in many later law dictionaries without questioning whether it was accurate. As it is, a more accurate statement of the law was given - almost at the same time the text of Malynes was produced. In Vanheath v Turner (1621), Hobart CJ made it clear that the law merchant was part of the common law and he referred to no ius gentium. ${ }^{804}$ That was also the view of Coke. In his Institutes of the Laws of England, volume 1 (on Littleton), first published in 1628, Coke referred to:

legem mercatoriam, which...is part of the laws of this realm, for the advancement and continuance of commerce and trade, which is pro bono... ${ }^{805}$

\footnotetext{
${ }^{795}$ Malynes, $\mathrm{n} 22$ ( $3^{\text {rd }}$ ed, 1686), vol 1.The edition of [1686] contained, inter alia, (a) a collection of sea laws by Welwod (a professor of civil law, published in 1613); (b) Marius on Bills of Exchange (1651)(see n 693); (c) Laws of Oleron (see 17); (d) Laws of the Hanse towns (see 17). For Malynes, see Rogers, n 12, p 84 et seq; Coquillette, n 13, pp 133-40 and Holdsworth, n 26, vol 5, pp 131-2.

${ }^{796}$ It is more a text for merchants/traders, based on FB Pegolotti (ed A Evans), La Practica della Mercatura (Medieval Academy of America, 1936)(Book of Descriptions of Countries and Measures, c. 1310-40). Pegalotti was an agent for the Florentine bankers. For an earlier text purporting to be a law book for English merchants, containing a translation of an Edict of Henry II of France in 1556 establishing the royal exchange in Rouen for merchants, see Anon, The Merchants new Royal Exchange or A Law Book for English Merchants (London, 1604, rep EEBO).

${ }^{797}$ Preface. Cited by MacDonell, n 375, p lxxxi. See also Holdsworth, n 26, vol 1, p 570.

${ }^{798}$ In his Dedication to James $I$ [1603-25] in the 1622 ed. Also, 'the law merchant... has proved always firm and inviolable.' In his Address to the Reader, Malynes stated: 'Law merchant...the same does properly consist of the custom of merchants, in the course of traffic, and is approved by all nations...'. Ibid. 'the law merchant, the knowledge whereof is of so great consequence that without it all temporal laws are not complete, but imperfect.' Ibid. 'even as the roundness of the globe of the world is composed of the earth and waters, so the body of lex mercatoria is made and framed of the merchants' customs and the sea laws, which are involved together as the seas and the earth.' Malynes cited no legal cases to support these statements.

${ }^{799}$ Malynes, n 22 ( $3^{\text {rd }}$ ed, 1686), p 4 defined a merchant as 'he that continually deals in buying and selling of commodities, or by way of permutation of wares at home and abroad in foreign parts, is a merchant.'

${ }^{800}$ Ibid, p 1. He considered the most ancient evidence of Abraham's merchandising was his purchasing a field for burial. Ibid, p 3 'the said customary law of merchants, has a peculiar prerogative above all other customs, for that the same is observed in all places, whereas the customs of one place, do not extend in other places...But the customs of merchants concerning traffic and commerce, are permanent and constant...'

${ }^{801}$ Thornely, n 32, p 32 'Malynes, who writes as a merchant rather than as a lawyer, is in many points discredited.'citing Goodwin v Robarts (1875) LR 10 Exch 347 per Cockburn CJ at p 347. Baker II, n 38, p 1266, n 18 'Malynes [his text] is more a guide to trade practice than a law book.' Ibid, p 1270 'a treatise on mercantile practice rather than a work of mercantile jurisprudence.'

${ }^{802}$ Roberts, $\mathrm{n} 6$.

${ }^{803}$ Cowell, $\mathrm{n}$ 762(lawe merchant) 'is a privilege or special law differing from the common law of England, and proper to merchants and summary in proceeding.' Cowell cited the Statute of Merchants 1285 and Statute of the Staple 1353. See also Baker I, n 38, p 1256 , fn 82.

${ }^{804}$ See n 737. See also Holdsworth, n 26, vol 5, p 146.

${ }^{805}$ Coke, n 16, vol 1, 182. See also Ibid, 172a. Also, Ibid, vol 2, p 57 'merchants strangers...have speedy recovery for their debts and other duties, etc per legem mercator; which is part of the common law.' See also Baker I, n 38, p 1255. The view of Hale CJ both in respect of the law merchant and maritime law was the same. M Hale, The History of the Common Law of England (ed CM Gray, Univ. of Chicago Press, 1971),
} 
In conclusion, there was a mis-match between what Malynes, a merchant, was writing and what judges were writing.

\section{(c) Godolphin (1661)}

A civilian and judge of the HCA, Godolphin, in his A View of the Admiral Jurisdiction (1661), ${ }^{806}$ stated:

all maritime affairs are regulated chiefly by the imperial laws, the Rhodian laws, the laws of Oleron, or by certain peculiar municipal laws and constitutions, appropriated to certain cities bordering on the sea, or by those customs... between merchants and mariners...It is most true that the civil law in England is not the law of the land, but the law of the sea.... ${ }^{807}$

Godolphin failed to note that the Laws of Oleron were, generally, treated as part of English law (see 17(e)). He also cited no evidence that other foreign maritime laws - such as the Rhodian law, Consolato del Mare, the laws of Visby etc. - were uniform or that the HCA applied them directly as a ius gentium, as opposed to considering them only as persuasive. It may also be noted that Godolphin adopted a narrower definition of 'merchant' than hitherto where it had tended to refer to anyone who bought and sold as a profession. Godolphin stated:

not every one that buys and sells, is ...to be denominated a merchant, but he only who in the way of trade and negotiation deals in movables for gain or profit, upon design of disposing thereof in the way of commerce either by importation, exportation, or otherwise, in the way of emption, vendition, barter, permutation, or exchange.

In his definition, one who bought and sold 'one off' was not a merchant. ${ }^{808}$ However, a person could be a merchant by repute. ${ }^{809}$ Artisans were excluded ${ }^{810}$ but bankers were included. ${ }^{811}$ Although Godolphin took his definition of a merchant from civilian writers, it was adopted by Jacob in the first edition of his law dictionary in 1729 and it was widely followed thereafter.

\section{In conclusion, Godolphin narrowed the definition of a 'merchant.'}

\section{(d) Zouch (1663)}

Support for the idea of the law merchant being part of a ius gentium also came from Zouch, a judge of the HCA. In his Jurisdiction of the Admiralty of England Asserted (1663), ${ }^{812}$ a work published posthumously, he stated:

The law merchant is likewise mentioned, and allowed by Sir Edward Coke, in his comment[ary] upon Littleton, as a law distinct from the common law of England. ${ }^{813}$ And so does Mr Selden mention it, in his notes upon Fortescue. ${ }^{814}$ And Sir John Davis more fully owns it in a manuscript tract touching

p 18 'the common law includes...lex mercatoria, as it is applied under its proper rules to the business of trade and commerce.' Ibid, p 24 , the admiralty court 'is not bottom'd or founded upon the authority of the civil law, but has both its power and jurisdiction by the law and custom of the realm, in such matters as are proper for its cognizance...' See also Baker II, n 38, p 1255.

${ }^{806}$ See n 7. Godolphin (1617-78), a lawyer, was a judge of the HCA during the Commonwealth. See Coquillette, n 13, pp 186-9.

${ }^{807}$ Godolphin, n 7, Preface and p 174. Cited by Scrutton, n 188, p 174.

808 'So that he is not properly said to be a merchant, who once and no more does buy commodities that he may sell the same, for it is not one act that does denominate a merchant, but a certain assiduity or frequent negotiation in the mystery of merchandising, unless he be matriculated or entered as such in the society or corporation of merchants.'

809 'He also may be said to be a merchant, who by common fame and in the opinion of men is commonly reputed a merchant.'

810 'They that buy wares or merchandizes to reduce them by their own art or industry into other forms than formerly they were of, are reputed rather artificers than merchants; unless by their order they are so transformed by the art and industry of others upon design of selling the same to gain thereby, in which case they may be said to be rather merchants than craftsman or artificers.'

${ }^{811}$ Ibid 'such as buy wares for present money, that without altering the form thereof they may sell the same at a future day of payment at a far dearer price than they were bought, are reputed rather usurers than merchants. But bankers, money changers, and such as deal by way of exchange are reputed under the notion of merchants. For whereas it is formerly said that a merchant deals only in movables, understand that money is comprised under that notion. So also are ships.' Godolphin also did not treat sailors (or the ship's captain) as a merchant.

${ }^{812}$ On Zouch, see Coquillette, n 13, pp 174-82. He was appointed a judge of the HCA in 1641 but lost his position during the Commonwealth. Re-appointed in 1661, he died in 1662. See also Pritchard, n 218, p cxiii.

${ }^{813}$ Littleton in his Tenures, see Coke, $\mathrm{n}$ 168, vol 1, 113 (s 169) had stated that 'a custom, used upon a certain reasonable cause, depriveth the common law [quia consuetudo, ex certa causa rationabili usitata, privat commune legem].' See also Coke, vol $133 \mathrm{~b}$ 'consuetudo tollit commune legem.' (custom ousts (or supercedes) the common law). This may have lent support to civilians who argued that mercantile law was distinct from the common law. One would suggest that Littleton probably meant to indicate that local custom, being particular, ousted the common law which was general. However, there is no reason to believe that Littleton did not think that a proved custom that was reasonable was 'part of' the common law in a wider sense, which was Coke's view, text to $\mathrm{n} 801$. See also Coquillete, n 13 , p 130 .

${ }^{814}$ Fortescue himself did not assert this; the only reference he made to the law merchant seems to be as follows: S Lockwood (ed), Sir John Fortescue, On the Laws and Governance of England (Cambridge UP, 1997), p 46, art 32 'in courts of certain liberties in England, which proceed by the law merchant, contracts among merchants made outside the realm are proved by witnesses. This is because in these cases 
impositions [see (b)] ...Whereby it is manifest that the causes concerning merchants are not now to be decided by the peculiar and ordinary laws of every country, but by the general laws of nature and nations. $^{815}$

This was tendentious since Coke's view was the opposite. ${ }^{816}$ Nor did Fortescue indicate that the law merchant was a law distinct to the common law. Zouch also stated:

I suppose no man will deny but the civil or imperial laws, the roll of Oleron, and others (by which, I suppose, may be understood, the articles of the Inquisition of Quinborough [see text to n 636]) are of force in the admiralty of England ... ${ }^{817}$

the kingdom of England is not destitute of special laws for the regulating of sea businesses, which are distinct from the common laws of the realm; as namely, the civil law, and others, of which the books of common law take notice by the names of ley merchant and ley mariner...businesses amongst merchants and seamen, are to be determined according to the civil law, and equity thereof, as also, according to the customs and usages of the sea...

instruments made beyond the sea have usually clauses relating to civil law, and to the law of the sea. ${ }^{818}$

As with Godolphin, Zouch failed to note that the Laws of Oleron were, generally, treated as part of English law and he also cited no evidence that other foreign maritime laws - such as the Rhodian law, Consolato del Mare, the laws of Visby etc. - were uniform or universal.

\section{In conclusion, Zouch provided no evidence of a ius gentium in the maritime field.}

\section{(e) Molloy (1769)}

Finally, a lawyer, Molloy, in his Treatise of Affairs Maritime and of Commerce (I quote from the last ed,in 1769) 819 supported the idea of a ius gentium in the maritime field. He stated:

Merchandise is so universal and extensive, that it is in a manner impossible, that the municipal laws of any one realm should be sufficient for the ordering of affairs and traffic relating to merchants. The law concerning merchants is called the law merchant from its universal concern, whereof all nations do take special knowledge, and the common and statute laws of England take notice of the law merchant, and leave the causes of merchants in many instances to their own peculiar law. ${ }^{820}$

Molloy's text went through a number of editions and it, doubtless, influenced others. ${ }^{821}$

neighbours, by whose oath juries of twelve men can be made, are not to be found, as is customary in contracts and other cases arising in the kingdom of England.' See also Fortescue, De Laudibus Legum Angliae (E\& R Nutt \& R Gosling, 1737) (with notes by J Selden). See also Scrutton, n 188, p 178.

${ }^{815}$ Ibid, p 89. Zouch continued 'He [Sir John Davis] says further 'That until he understood the difference between the law merchant and the common law of England, he did not a little marvel, that England, entertaining traffic with all nations of the world, having so many ports, and so much good shipping, the king of England also being lord of the sea, what should be the cause that, in the books of the common law of England, there are to be found so few cases concerning merchants or ships: but now the reason thereof was apparent, for the common law of the land did leave those cases to be ruled by another law; namely, the law merchant; which is a branch of the law of nations.'

${ }^{816}$ Zouch had previously stated, n 19, vol 1, p 89 'Touching the civil law, how it is observed in the admiralty of England, Sir Edward Coke shows, in his comment upon Littleton, where he mentions divers laws which are in use in this kingdom'.

${ }^{817}$ Ibid, p 95. Zouch also quoted Sarjeant Callis in his Reading on the Statute of Sewers (delivered in 1622, see $2^{\text {nd }}$ ed, 1685) p 42 'I acknowledge that the king rules on the sea by the laws imperial, as by the Roll of Oleron and other; but that is only in the particular case of shipping; and for merchants and mariners.' However, Callis cited no authority for this remark which was by way of an aside.

${ }^{818}$ Ibid, pp 89 \& 118. See also Scrutton, n 188, p 173 (who slightly misquotes).

${ }^{819}$ Molloy was a civilian and a member of Lincoln's and Gray's Inns. On him, see Coquillette, n 13, pp 124-46. See also Holdsworth, n 26, vol $5, \mathrm{p} 131$.

${ }^{820}$ Molloy, n 20 ( $9^{\text {th }}$ ed, 1769), vol 2, p 322-3. Molloy, vol 2, pp 319-20, defined a 'merchant' as 'Every one that buys and sells is not from thence to be denominated a merchant, but only he who traffics in the way of commerce, by importation or exportation, or otherwise in the way of emption, vendition, barter, permutation, or exchange, and which makes it his living to buy and sell, and that by a continued assiduity, or frequent negotiation in the mystery of merchandizing. But those that buy goods to reduce them by their own art in industry into other forms than formerly they were of, are properly called artificers, not merchants... but persons buying commodities, though they alter not the form, yet if they are such as sell the same at future days of payment for greater price than they cost them, they are not properly called merchants, but are usurers, though they obtain several other names, as warehouse-keepers, and the like, but bankers, and such as deal by exchange, are properly called merchants.' This definition was the same as in the $2^{\text {nd }}$ ed, 1677, pp 436-7.

${ }^{821}$ Such as Sir Bartholomew Shower in Carter v Dowrish (1689) Show 127 (89 ER 492) at p 128 'It is not like a particular custom, which is confined within a certain precinct in this realm, but it is of universal extent, and concerns the whole realm; nay, reaches further, for it is ius gentium, and concerns all countries where traffick is used.' See also Baker I, n 38, p 1255. Holdsworth, n 26, vol 6, p 326 cited Jeffreys CJ in East India Co v Sandys (1684) 10 ST 371, 509 who asserted that all matters connected with foreign trade were determined by the universal law 


\section{(f) Analysis of Baker}

In an article on The Law Merchant and the Common Law before 1700, Baker noted that there was confusion in respect of the concept of law merchant 'which has been differently understood by different writers and continues to be used in widely divergent senses. ${ }^{822}$ Baker specified 4 divergent views of the law merchant, viz.

- Distinct System of Law. The law merchant was a distinct, and independent, system of law, akin to civil or canon law and (perhaps) derived from Roman law; ${ }^{823}$

- Ius Gentium. The law merchant was an aspect of the ius gentium (and, as such, akin to international law); ${ }^{824}$

- Immemorial Custom. The law merchant was a form of immemorial custom; ${ }^{825}$

- Changeable Usages of Merchants. The law merchant was the same thing as mercantile practice. That is, the changeable usages of merchants. ${ }^{826}$

In a later article, Law Merchant' as a Source of English Law, Baker added two more views:

- Specialist Courts. The law merchant was the same as the customary practices of certain specialist courts such as the court of piepowder; ${ }^{827}$

- Part of Common Law. The law merchant was that part of the common law which handled mercantile (commercial) matters ${ }^{828}$ - with a variant being that the law merchant had become absorbed into the common law and no longer had an independent existence. ${ }^{829}$

In respect of the law merchant being a distinct system of law or part of a ius gentium, Baker stated:

it is far from clear [the] law merchant was ever conceived of as a distinct body of substantive law. There were no doctors in lex mercatoria, and even the ius gentium was not taught in the university law schools. Most of the medieval literature consists in codes of mercantile procedure observed in particular cities and towns; at this level, far from there having been a universal law throughout the world, the local

merchant which was a branch of the ius gentium and that 'All other nations have governed themselves by this principle; and upon this ground stands the court of Admiralty in this kingdom viz. that there might be uniform judgments given there to all other nations in the world, in causes relating to commerce, navigation and the like. And in as much as the common and statute laws of this realm are too strait and narrow to govern and decide differences arising about foreign commerce, and can never be thought to bear any sort of proportion to the universal law of all nations, as the interests of all foreign trade do necessitate them to contend for; it will become us that are judges in Westminster Hall...to.. take notice of the laws of nations.'

${ }^{822}$ Baker I, n 38, p 1233.

${ }^{823} \mathrm{Ibid}, \mathrm{p} 1233$ 'Some have regarded it as a distinct and independent system of legal doctrine, akin in status to civil or canon law, and perhaps derived from Roman law.' Baker cited, inter alia: (a) Scrutton, n 188, pp 177-86; (b) Carter, n 27, p 240 who stated 'Possibly the law merchant was the channel through which the Roman law chiefly affected our law.'; (c) C Allen, Law in the Making (Oxford, $7^{\text {th }}$ ed, 1964), p 274, who stated that the law merchant was 'profoundly affected' by Roman law; (d) Mitchell, n 30, pp 160-1 'Roman law was, in the main, the basis of the law merchant...But great as was the influence of Roman law, the customs and usages of the merchant himself remained the decisive factor... Roman law was the raw material of the law merchant, but that material the medieval merchant fashioned and framed as seemed good to him.' As Baker noted, p 1234, n 5 'This assumes a rather surprising degree of legal erudition on the part of the medieval merchant.' See also Baker II, n 38, p 1265. Also LE Trakman, Evolution of the Law Merchant (1981) 12 Journal of Maritime Law and Commerce at p 154.

${ }^{824} \mathrm{Ibid}, \mathrm{p} 1234$ 'a particular aspect of natural law, or the universal ius gentium, and as such akin to international law.' Baker cited, inter alia: (a) Davies; (b) Zouch; (c) HJ Berman \& C Kaufman, The Law of International Commercial Transactions (Lex Mercatoria) (1978) 19 Harvard International Journal, pp 224-9. See also Baker II, n 38, pp 1265-6. See also isolated statements such as Mogadara v Holt (1691) 1 Show KB 317 (89 ER 597) at p 318 per Eyre J 'the law of merchants... is ius gentium, and we are to take notice of it.'

${ }^{825} \mathrm{Ibid}, \mathrm{p} 1234$ 'Another school regards it as a form of immemorial custom, which by familiarity was eventually noticed by the common-law judges in the same way as the customs of gavelkind and borough English was judicially noticed, without formal proof.' Baker cited Blackstone (see 21). Also, Baker II, n 38, p 1266.

${ }^{826} \mathrm{Ibid}, \mathrm{p} 1234$ 'which was doubtless influenced by the seventeenth- century writer Malynes, is that the law merchant is the same thing as mercantile practice, the changeable usages of merchants'. Baker cited, inter alia, (a) Malynes; (b) Cockburn CJ in Goodwin v Robarts (1875) LR 10 Ex 337; (c) Postan (a historian), n 692, p 61 'everything which entered into the everyday practice of merchandise and was indispensable for the efficient conduct of trade was, eo ipso, part and parcel of merchant custom and thereby sanctioned by the law merchant.'; (d) Sutherland, n 37. See also Baker II, n 38, pp 1266-7.

${ }^{827}$ Baker II, n 38, p 1267 'synonymous with the customary practices of specialist mercantile jurisdictions such as the courts of piepowder... Since such jurisdictions were largely in the hands of merchants, they could be regarded as a form of dispute-resolution which operated, without recourse to law at all, in any technical sense.'

${ }^{828}$ Ibid, the law merchant - for the purposes of English law - is that part of the common law which concerns mercantile affairs.'

${ }^{829}$ Ibid. 
variations seem as numerous as the coincidences. ${ }^{830}$

This would seem (indubitably) correct since:

- $\quad$ Fair \& Markets. There is no evidence there was a universal law on fairs and markets - one which the English courts in 1290 (when fairs in England were at their zenith) or later, could apply. ${ }^{831}$ Further, modern research on Continental fairs and markets in early times indicates diversity rather than uniformity. ${ }^{832}$ In respect of a distinct body of substantive law merchant, there is also a lack of evidence under English law. Rather, at most, there was a summary process (pie powder) in markets and fairs, soon to be availed of by non-merchants (and merchants could also choose the common law courts). ${ }^{833}$ Also, by 1290, there were a few privileges given to merchants in respect of summons, attachment, proof etc.;

- Maritime Courts \& Customs. Although Baker did not analyse these, the same applies in respect of maritime customs. Laws commonly cited as disclosing some form of universal custom, such as Rhodian law, the laws of Oleron, the laws of Visby etc., had many variants. Further, they were not identical in their propositions of law. Also, the most cited in English cases - the Laws of Oleron - were thought to be part of English law;

- BOE \& Promissory Notes. As Rogers noted, there was no evidence of a distinct law merchant or a ius gentium . Further, early Continental literature evinces no ius gentium. ${ }^{834}$ And, although (like the common law) some continental law was prepared to accept mercantile custom as law when accepted by the ruler, ${ }^{835}$ this neither made it a distinct law, nor universal in scope.

As for the view that the law merchant comprised the changeable usages of merchants (which was usually also linked to Baker's fifth view, of its also being derived from specialist courts) and that it was a separate field of law which was eventually incorporated into the common law - a view expounded by Holden (who followed Holdsworth and Cranch) - one which Baker called the 'orthodox view' ${ }^{836}$ it is asserted that:

- This fails to note that the courts - in early times - were treating mercantile custom no different to other customs (including London customs) and that the law merchant was treated as part of the common law as far back as c. 1280 - and not as part of the common law only by 1666 (as Holden alleged);

- Further, one would agree with Baker that such a view of the law merchant confused 'usage' with 'custom'. The usage (business practice) of merchants was never part of English law; ${ }^{837}$ it only became

${ }^{830} \mathrm{Ibid}, \mathrm{p} 1234$. See also Baker II, n 38, p 1268 'The principal difficulty with it [that the law merchant was distinct] is that it is not historically true.'

${ }^{831}$ See also Baker I, n 38, p 1328, fn 23. Baker cited D de Ruysscher, From Usages of Merchants to Default Rules (2012) 33 JLH 3-29 (no ius gentium re Antwerp).

${ }^{832}$ See the articles referred to in Piergiovanni I and II, $\mathrm{n} 41$.

${ }^{833}$ Baker I, n 38, p 1241 'That the merchants dominated the urban and fair jurisdictions is very likely, but it does not follow that they disdained to use the central courts.' Sutherland, n 37, p 152 'To the medieval lawyer the jurisdiction of the merchant courts was little more than a limited devolution of authority made in the interest of speed and simplicity. The common law courts did not hesitate to try cases involving merchants if the occasion arose.'

${ }^{834}$ See e.g. Pegolotti, n 796; J Nider (trans CH Reeves), On the Contracts of Merchants (University of Oklahoma Press, 1966)(De Contractibus Mercatorum, c. 1468) and Scott, n 614, vol 4, Pt 5, title 7 (concerning merchants, fairs and markets).

${ }^{835}$ See, for example, the influential writings of the Jesuit and Spanish professor of law, F Suarez, A Treatise on Laws and God the Law Giver (De Legibus ac deo Legislatore, 1612, trans Williams et al, Liberty Fund, 2015), p 515 'If....custom be reduced to writing by one who has authority to establish law, it ceases to be custom by the very fact that it is so written: it is now written and not unwritten law, and is law not by tacit but by express consent.' Ibid, p 603 'a community of merchants has not power to make law, yet a custom of theirs can establish a legal rule...' Ibid, p 605, '[a] body of merchants... has power to frame conventional statutes only [ed. that is, statutes which regulate the merchant body] but not true laws. If, however, it be regarded as united with the prince or as wielding authority granted by him, this merchant body has power to frame statutes of a quasi-municipal character. Hence, it can establish custom, which has, with the same limitations, the force of law.' Ibid, p 648 'the Spanish law [Las Siete Partidas, see n 614] requires no more than that the custom be established with the consent of the prince.' Ibid, p 507 'An evil custom...creates no legal force.'

${ }^{836}$ Baker I, n 38, pp 1234-5 referred to Holden's version as the 'orthodox' view on this (one would agree). The basic tenor of this was that, until the $16^{\text {th }}$ century, the law merchant was confined to special courts, such as those of piepowder and admiralty. However, in the $17^{\text {th }}$ century, the principle developed that mercantile custom could originate a legal duty on which the plaintiff could declare in an action on the case. Two technical difficulties were then overcome: viz. the custom (a) had to be immemorial. This was held to be unnecessary; (b) it had to be local, not general. This was overcome, in 1666, when the courts declared 'by one of the boldest fictions known in our legal history' (Holden) that the custom was part of the law of the land and, thereby, applied to everyone. Further, by 1693, it was held that such a custom did not need to be laid in any particular locality. Finally, thanks to Mansfield CJ, the courts took notice of mercantile custom and treated it as part of the law.

${ }^{837}$ Baker II, n 38, p 1266, n 17 'The supposed rules of the law merchant were originally pleaded as customs (consuetudines) of particular cities, as the custom of merchants (usus vel consuetudo mercatorum), but never as lex mercatoria.' Cf. p 1270 'When seventeenth-century English 
so when legislation or the courts accepted it, 'universalizing' it. Thus, the expression 'law merchant' could only, accurately, apply to the latter. However, it was often, incorrectly, used to describe the usage (business practices) of merchants - something easy to comprehend since merchants, when discussing matters in common speech, were not seeking to distinguish usage from custom in legal terms and probably did not know the difference anyway.

\section{In conclusion, Baker adverted to the confused use of the term 'law merchant' since it was being used in a number of different ways.}

\section{(g) Conclusion}

The writings of Davies, Malynes, Molloy, Godolphin and Zouch are indicative of expansive statements not being supported by factual evidence (further, the latter two restricted their views to maritime matters and Malynes was a merchant). Out of all of them only Davies provided some detail as to the supposed technical differences between the law merchant and the common law. However, it evidenced no distinct law and the very examples he gave contradicted a ius gentium. In his two articles, Baker concluded that:

Mercantile customs were either local facts or they were the common law of England. In so far as the judges took notice of such customs as common law, they were not taking over for their own use a pre-existing body of jurisprudence. The lex mercatoria in its principal medieval sense of speedy procedure was never adopted by the common law... ${ }^{838}$ The substantive mercantile law, on the other hand, had no existence as a coherent system of principles before the common law itself developed the means of giving it expression...To the extent that there was a law merchant before Lord Mansfield, it was not an importation from the ius gentium, though without doubt internationally current moral views and economic practices informed this branch of the law as they informed others. ${ }^{839}$...Whatever the seventeenth-century writers may have said in vague rhetorical terms about the lex mercatoria in England, there was nothing arcane about it. It was in reality nothing more than a refinement of the common law which had always governed mercantile affairs. ${ }^{840}$

One would agree. There is no evidence of any universal continental practice to which the English courts could refer to, including in the areas of maritime and insurance law (which Baker did not deal with). Nor was the law merchant distinct. ${ }^{841}$ Indeed, there is nothing to suggest that - in the $17^{\text {th }}$ century - the courts were doing anything different to what they were doing c.1280. ${ }^{842}$ Further, none of Davies, Malynes, Zouch etc. drew attention to the fact that many early privileges accorded to merchants derived from London customs which had legislative approval as a result of Magna Carta ${ }^{843}$ or which stemmed from an Ordinance(s) of Edward I $(1272-1307){ }^{844}$ They were unaware of this - just as Coke CJ who had been the Recorder of the City would (likely) have been aware of this.

\section{In conclusion, Davies, Malynes, Molloy, Godolphin and Zouch mis-stated the law. The law merchant did not}

lawyers referred to the law merchant, they seem to have meant the general assumptions and working practices of merchants of the day...rather than rules of law found in a body of learned literature.' Ibid, p 1277 'Fluctuating usage derives such force as it has solely from the express or implied consent of individual parties, but cannot create legal obligations independently of the law of contract. It therefore cannot be competent to a body of tradesmen, however large, to invent laws to bind other people without their knowledge.'

${ }^{838}$ Ibid, p 1261. Baker continued: 'at any rate, not until the establishment of the Commercial Court in the 1890's, and that was more a case of unconscious repetition than of borrowing.'

${ }^{839}$ Ibid. Baker continued 'Neither was it in any recognisable sense the law of the specialist mercantile courts of fairs, boroughs and admirals, though we may reasonably suppose that merchants in a piepowder or guildhall court would have administered the same kind of justice as merchants on a jury at nisi prius.'

${ }^{840}$ Ibid. Baker continued, p 1261 'And the process of refinement was not one of borrowing ready-made law from other jurisdictions, in the way that the developed canon law was adopted into the common law after the Reformation. It was a crystallisation of principles which had previously been left to the general knowledge and common sense of City juries. The procedures which precipitated those principles as positive law were developed, not by medieval mercantile tribunals or international conference, but by the common law courts of the Renaissance period. And the common-law courts did not operate those procedures by 'incorporating' a law merchant in any of the usually accepted senses of that term. They used them to create it.'

${ }^{841}$ Baker II, n 38, p 1274 'It is a myth, therefore, to suppose that there was at some point in history a comprehensive body of mercantile law current throughout the world - or even, to put it considerably lower, in the special courts belonging to merchants in England - and waiting to be incorporated into the common law by Lord Mansfield and others.' Ibid, p 1282.

${ }^{842}$ Baker I, n 38, p 1238 'At the level of substantive principle...it is doubtful whether any distinctions were made at all between the law merchant and the common law.' Certainly, issues re summons, attachment and no wager of law on the negative side are procedural. See 14. So too, burden of proof re a tally (sealed or not) or an oral agreement, see $\mathbf{8}$.

${ }^{843}$ See $n 174$

${ }^{844}$ See n 227 (text). 
derive from a universal ius gentium. Nor was it a distinct field of English law (even in the maritime area). This mis-stating may be explained by the fact that Davies was seeking to make a political point - as opposed to a legal one - Malynes was not a lawyer and Godolphin and Zouch were fighting to preserve the HCA's jurisdiction. ${ }^{845}$

\section{THE POSITION BY 1760}

In 1752, Beawes, a merchant, produced his Lex Mercatoria Rediviva or the Merchant's Directory which purported to deal with all matters relating to merchants. The work was popular and went through six editions until 1813. ${ }^{846}$ Beawes described a merchant (likely following Jacob in 1829) ${ }^{847}$ as follows:

The term merchant (in latin mercator) or trader, from tradendo...is in England, according to the general acceptation of the word, now confined to him who buys and sells any commodities in gross, or deals in exchange, that traffics in the way of commerce, either by importation, or exportation, or that carries on business by way of emption, vendition, barter, permutation, or exchange, and that makes a continued assiduity or frequent negotiation in the mystery of merchandising his sole business. It is true, that formerly every one who was a buyer or seller, in the retail way, was called a merchant, and they continue to be deemed so still, both in France and Holland, but here shopkeepers, or those who attend fairs and markets, have lost that appellation. ${ }^{848}$

Thus, the concept of 'merchant' was applying to a rapidly diminishing class of persons (see Appendix B). Beawes' directory is often overlooked. However, it was not only comprehensive, ${ }^{849}$ there was legal input by lawyers $^{850}$ and, thus, the chapters on BOE, maritime matters and insurance were particularly detailed. Regard should be had to this in light of the observation of Lord Campbell, in his Lives of the Chief Justices (1849), that, before Mansfield CJ (chief justice from 1756-88):

when questions necessarily arose respecting the buying and selling of goods, respecting the affreightment of ships, respecting marine insurances, and respecting bills of exchange and promissory notes, no one knew how they were to be determined. Not a treatise had been published upon any of these subjects, and no cases respecting them were to be found in our books of reports ... Mercantile questions were so ignorantly treated when they came into Westminster Hall, that they were usually settled by private arbitration among the merchants themselves. ${ }^{851}$

This was over statement. ${ }^{852}$ It also failed to note that, in 1760, Cunningham (a lawyer) had produced a large text (some 450 pages) on 'The Law of Bills of Exchange, Promissory Notes, Banknotes and Insurances'. ${ }^{853}$ Accepting that the law merchant was part of the common law, ${ }^{854}$ Cunningham bills of exchange and promissory notes in great detail. In so doing it is clear that - prior to when he wrote - the common law courts dealt with many

\footnotetext{
845 The only one who gave details of what the domestic law merchant was, was Davies.

${ }^{846}$ Other practical texts for merchants of this time were: (a) M Postlethwayt, Universal Dictionary of Trade and Commerce (1 ${ }^{\text {st }}$ ed 1751$)$; (b) $\mathrm{R}$ Rolt, A New Dictionary of Trade and Commerce (London, 1756); (c) T Mortimer, Elements of Commerce, Politics and Finances (London, 1772). Some of these were based, to an extent, on J Savary, Parfait Negociant $\left(1^{\text {st }} \mathrm{ed}, 1675\right)$ and his son's Dictionnaire Universel de Commerce (Paris, 1723-30).

847 See G Jacob, A New Law Dictionary (1 ${ }^{\text {st }}$ ed, 1729), see Appendix A.

${ }^{848}$ Beawes, n 21, p 25. Rolt, n 846 (merchant) had a similar definition. Beawes' definition was repeated in Tomlins, Law Dictionary (1797)(Tomlins took over editing Jacob's dictionary of 1729, see $\mathrm{n} 847$ ), vol 1, (merchant). Tomlins also noted that 'Bankers, and such as deal by exchange, are properly called merchants.'

${ }^{849}$ Thus, it dealt with, inter alia: (a) origins of trade; (b) factors, supercargoes and agents; (c) ship owners, captains and sailors; (d) freight, charter parties, bills of lading, demurrage and bottomry; (e) ballast; (f) pilots and lodesmen; (g) wrecks; (h) salvage, average or contribution; (i) ports, havens, lighthouses; (j) letters of marque and reprisal; (k) privateers, pirates, convoys and cruisers; (l) capture, condemnations and appeals; (m) embargoes, truces, declarations of war and peace; (n) admiralty; (o) consuls; (p) insurance; (q) arbitrators; (r) aliens; (s) banks and bankers; (t) usury; (u) customs; (v) BOE and promissory notes; (w) general trade.

${ }^{850}$ As noted in Beawes, $\mathrm{n} 21$, Preface, $\mathrm{p}$ vi.

851 J Campbell, The Lives of the Chief Justices (John Murray, 1849), vol 2, pp 402-3.

${ }^{852}$ One wonders whether Campbell took this from a much older text J Cary, Essay on the State of England in relation to its Trade, its Poor and its Taxes (Bristol, 1695), p 27 who argued for 'courts of merchants...for the speedy deciding all differences relating to sea affairs, which are better ended by those who understand them, than they are in Westminster Hall.' See also J Child, A Discourse about Trade (1690), p 112 (suggestions for a merchants' court). These are mentioned by Sutherland, n 37, pp 166, 168.

853 Cunningham, n 693.

${ }^{854}$ Ibid, vol 1, p 4, note (k), 'The custom of merchants is part of the common law of this kingdom, of which the judges ought to take notice; and if any doubt arise to them about their custom, they may send to the merchants to know their custom, as they may send for the civilians to know their law'. (Cunningham cited Van Heath $v$ Turner (1621), see $\mathrm{n} 737$ ). Ibid, p 5 'The custom of merchants in relation to foreign [BOE]... is now become part of the law of the land...'.
} 
cases on BOE and promissory notes and did not treat of them 'ignorantly. ${ }^{855}$ Also, Campbell failed to note how little of the 'law merchant' was left. The position in 1760 may be summarized in comparison to that in 1290 (see 14):

- $\quad$ Fair Courts. The zenith of fairs was reached by 1400. After 1466, merchants acted as assessors - not judges - in piepowder courts (see 13) and, by 1613 (if not before), there were likely few such courts, with those that existed available to non-merchants as well as to merchants. By 1760, piepowder courts were rare;

- BOE \& Promissory Notes. By 1622, BOE could be made by anyone, not just by merchants, ${ }^{856}$ and, by 1689 , it was unnecessary to refer to the 'custom of merchants' in a plea. ${ }^{857}$ Indeed, as early as the $16^{\text {th }}$ century, actions of assumpsit were used regularly in the King's Bench for enforcing BOE; ${ }^{858}$

- $\quad$ Statutes of Action Burnell 1283, Statute of Merchants 1285 \& Statute of the Staple 1353. By the $16^{\text {th }}$ century, these could be availed of by non-merchants (see 11 and 16 re Act of 1531). After 1660 (if not before) the staple, and its courts, became, effectively, redundant due to the prohibition on the export of wool. Further, recognizances (and their registration) was supplanted by BOE and promissory notes as an easier means of evidencing debt as well as securing recovery;

- Gilds. By the $15^{\text {th }}$ century, these were being replaced by (merged with) the craft guilds. Further, they were available to non-merchants;

- Admiralty Courts. By 1760, such local admiralty (and vice-admiralty courts) as existed were almost obsolete with the LHA (or common law courts) having taken such business. Maritime law had become increasingly statutory after $1660{ }^{859}$ and the Laws of Oleron (thought to be part of English law) as well as other foreign maritime laws (17(f)) were obsolete - or almost so.

At this juncture, mention may also be made of other matters which were discussed by some writers ${ }^{860}$ as being part of the law merchant:

- Insurance ${ }^{861}$ It is dubious whether the law on insurance derived from Roman law. ${ }^{862}$ MacDonell asserted that marine insurance was introduced into England by the Lombards and that it had become 'pretty general' by end of the $15^{\text {th }}$ century. ${ }^{863}$ He thought the earliest case was Dowdale (1605). ${ }^{864}$

\footnotetext{
${ }^{855}$ Nor did they do so after 1760, see, for example, Kyd, n 693 (in 1795). Indeed, there is nothing to suggest that the common law courts knew nothing of the law on the buying and selling of goods or BOE or promissory notes. However, it may be that they were less familiar than their admiralty counterparts of the law on freight or on marine insurance.

${ }^{856}$ See n 723. Cunningham, n 693, vol 1, p 39 'the bare drawing or accepting a bill makes a merchant for that purpose'. See also Hodges $v$ Steward (1691) 1 Salk 125 (91 ER 117) 'the drawing the bill was a sufficient merchandizing and negotiating to this purpose.' Ibid 'the court is to take notice of the law of merchants as part of the law of England.'

${ }^{857}$ Kiralfy, n 208, p 113 'Towards the end of the seventeenth century it became unnecessary to plead that the litigant was a merchant... Cunningham, $\mathrm{n} 693$, vol 1, p 79 'the custom of merchants concerning [BOE], being part of the common law of which the judges will take notice ex offiico, it is unnecessary to set forth the custom specially in the declaration, and that it is sufficient to say, that such a person, according to the usage and custom of merchants, drew the bill.'

${ }^{858}$ Baker II, p 1274 'During the sixteenth century, the action of assumpsit began to be used regularly in the King's Bench for the enforcement of bills of exchange, charter parties, marine insurance policies, and other commercial contracts; and this opened up the means of transferring business from urban courts to the courts of common law.'

${ }^{859}$ For example, ships were registered in 1660 (12 Car 2 c 18 s 10).

${ }^{860} \mathrm{See}$, in particular, those in $\mathbf{2 5}$.

${ }^{861}$ See generally, (a) N Magens, Essay on Insurances (1755, translation of an earlier work in German in 1753); (b) J Millar, Elements of the Law relating to Insurances (1787); (c) CF Trenerry, The Origin and Early History of Insurance including the contract of Bottomry (1926); (d) $\mathrm{J}$ Weskett, Digest of the Theory, Laws and Practice of Insurance ( $1^{\text {st }}$ ed, 1781, $3^{\text {rd }}$ ed, 1794); (e) J Bischoff, Marine Insurances ( $2^{\text {nd }}$ ed, 1836); (f) JA Park, System of the Law of Marine Insurance ( $1^{\text {st }}$ ed, 1787); (g) T Parker, Laws of Shipping and Insurance (1775); (h) F Martin, The History of Lloyds and of Marine Insurance in Great Britain (1876; it contains a useful bibliography); (i) M Bacon, A New Abridgment of the Law (5 ${ }^{\text {th }}$ ed, H Gwillim, 1798), vol 4, p 629 et seq.; (j) Bewes, n 34, ch 5; (k) R Lowndes, A Practical Treatise on the Law of Marine Insurance ( $1^{\text {st }}$ ed, 1881).

${ }^{862}$ Scrutton, n 188, p 183 'it does not seem that that law can be traced to Roman sources.' Also, apart from the fact that the Court of Insurance comprised two doctors of civil law 'there is no trace of Roman influence in the English law of insurance.' Lowndes, $\mathrm{n} 861, \mathrm{p}$ xviii, though that it had been invented by the Jews and the oldest mention in any ordinance was in Pisa in 1318. Ibid, $\mathrm{p} x \mathrm{x}$.

${ }^{863}$ Malynes, n 22 ( $3^{\text {rd }}$ ed, 1686), pp 105-6 asserted that the practice of assuring freight derived from the Romans (Claudius Caesar) which was then reflected in the laws of Oleron and then used in England. Also, "here in London, the meeting amongst merchants was in Lombard street in London....all the policies or writings of assurances, which there were and now yet are made, so make mention, that it shall be in all things concerning the said assurances as was accustomed to be done in Lombard street in London.' Repeated by Zouch, n 19 (in Malynes, $n 22$ ( $3^{\text {rd }}$ ed,
} 
- Not Restricted to Merchants. While it is likely that the practice of insurance did derive from merchants ${ }^{865}$ - and that those who effected insurance in early history called themselves 'merchants' (or traders) - there was no restriction on non-merchants acting as insurers or insured. ${ }^{866}$ Thus, insurance was a not part of the law merchant as such, although it was often viewed in the context of 'mercantile' law;

- Commission on Insurance. Further, while merchants likely settled insurance disputes by arbitration, rather than by recourse to the courts in Elizabethan times ${ }^{867}$ an Act concerning matters of Assurances among Merchants 1601 established a special commission - consisting of a judge of the Court of admiralty, two doctors of civil law, two common lawyers, and eight 'grave and discreet merchants' - to try matters relating to marine insurance in respect of policies registered in London. ${ }^{868}$ However, this court lapsed into obsolescence, ${ }^{869}$ probably before $1729 .{ }^{870}$ This may have been due to partiality; ${ }^{871}$

- No Ius Gentium. Finally, there is no evidence that the English courts had regard to foreign legal texts on insurance and applied them directly (or even as persuasive authority) in English law. For example, the first text on insurance is usually cited as being Santerna, Treatise on the Assurances and Promises of Merchants. ${ }^{872}$ Not only does this text contain many extraneous personal observations, such to make it clear that it can hardly be disclosing a ius gentium ${ }^{873}$ many of its propositions had already been pre-empted by English law ${ }^{874}$ or were at variance

1686), vol 1, p102 which contains his text). See also Cunningham, n 693, pp 145-6 and Martin, n 861, ch 1. See also Mitchell, n 30, p 141 et seq and Scrutton, n 188, p 183.

${ }^{864}$ Dowdale's Case (1605) 6 Co 48 (77 ER 323), p 47b. Cf. Bewes, n 32, p 66 (1533).

${ }^{865}$ Fitz-gerald v Pole (1754) 4 Bro PC 439 (2 ER 297) at p 444 'Though different accounts are given of the invention of insurances, yet they certainly were brought into practice by merchants, for the sake of trade, and in order to divide the risk.' Holdsworth, n 26, vol 5, p 130 'the whole law and practice of insurance originated in the first instance from the merchants themselves'. He cited 43 Eliz 1 .c 12 (see n 868) which stated, in its Preamble, that insurance: 'has been time out of mind a usage among merchants.'

${ }^{866}$ Bacon, n 861, p 629 'By the common law and usage of merchants, any person might be an insurer.' See also J Williams, Laws of Trade and Commerce ( $1^{\text {st }}$ ed 1812), p 291 (in 1812) 'By the common law and usage of merchants, any person whatever might be an insurer.' Ibid. 'In this country, all persons, whether British subjects or aliens, may, in general, be insured.' See also Potts, n 357 ('At common law, any man or company of men might have been insurers...') and W Smith, Compendium of Mercantile Law ( $3^{\text {rd }}$ ed, 1855), p 412.

${ }^{867}$ MacDonnell, $\mathrm{n}$ 375, p lxix 'Merchants disposed of such disputes in their own courts or in some domestic forum.'

86843 Eliz 1 .c 12 (1601, rep 1863). See also Senior, n 520, p 82. Martin, n 861, ch 1, thought that this Act 'was closely modelled on the insurance legislation of the Hanseatic League, and its passing was probably due to the influence exercised by the growing body of merchants of London engaged in foreign commerce, who had the field all to themselves after the departure of the denizens of the Steelyard.'

${ }^{869}$ Jacob (in 1729) stated, n 847, p 85 'now there is no such court in being, but such causes are try'd in the ordinary courts.'

${ }^{870}$ MacDonnell, $\mathrm{n}$ 375, $\mathrm{p}$ lxix 'The court proved of little use. The tendency of the superior courts to draw to themselves all lucrative business was too strong. A blow at the utility of the commission was struck by the decision in Came v Moye [1658, see 2 Sid 121 (82 ER 1290)], that a judgment by the commissioners was no bar to an action at law. Prohibitions to restrain them were issued, and the court fell into disuse. Writing in 1787, Park J observes that no commission had issued for many years.' See also Park, n 861, p xl (1789 ed) 'I am sure I rather go beyond, if I assert that in all our reporters, from the reign of Queen Elizabeth, to the year 1756...there are sixty cases upon matters of insurance.' Postlethwayt, n 846 (1774 ed) (assurance) 'no such court in being, and causes of this nature are tried in the ordinary courts of law.' See also Pritchard, n 218, p lxxxi, n 3; Holdsworth, n 26, vol 1, p 571; Martin, n 861, ch 1 and Lowndes, n 861, p xxvi.

${ }^{871}$ Beawes, $\mathrm{n} 21, \mathrm{p} 223$ explained that 'there being some defect in the [Act of 1601] touching the power of the commissioners, its continuance was not of long duration. But by a new Act of Parliament [13 \& 14 Car II c 23, 1662, rep 1863]...large powers were given to the Commissioners for carrying it into execution, and in consequence of this last Act, several insurances were made, and all disputes concerning them were determined by the Commissioners, but as private persons were not excluded thereby, from carrying on this business as before, and the Commissioners taking no cognizance of any policies not made in their office, and recovery of losses thereon being made easy at common law, besides, there having been some partiality practiced by the Commissioners, and an appeal being allowed from their determinations to the court of Chancery, the business of the court soon diminished, and the granting commissions was discontinued.' See also Cunningham, n 693, vol 1, p 153 quoting him.

${ }^{872}$ P Santerna, Tractatus de Assecurationinbus et Sponsionibus (1552, rep 1971, Gremio dos Seguradores, with English translation).

${ }^{873}$ e.g.(a) p 334 (title 16), whether the Jews should be wiped out as enemies of the Christian faith; (b) Ibid, (title 19), the Turks and Africans are enemies of the Christian empire; (c) (c) Ibid, (title 23), generally speaking all Jews are accursed rogues; (d) p 287 (title 52) immoderate snows usually rot cereals etc, etc.

${ }^{874}$ e.g, pp 231-2 (a) (title 2) between merchants there is no rigid application of the law, but rather of the rules of equity. Cf. London charter of 1341 (good faith and reason), see n 231. 
with the same. ${ }^{875}$ Further, there is no evidence that Santerna was writing a text to reflect any ius gentium. Indeed, he observed that custom was not extensive from one place to another; ${ }^{876}$

- By 1760, Cunningham noted in respect of insurance: 'The policies now a-days are so large, that almost all those curious questions that former ages, and the civilians according to the law marine, nay and the common lawyers too, have controverted, are now out of debate. Scarce any misfortune that can happen, or provision to be made, but the same is provided for in the policies that are now used...' 877

In conclusion, insurance was not part of the law merchant as such, since a person who was an insurer or insured did not have to be a merchant.

- Banking. As Holdsworth noted, banking was not a distinct business in the reign of Elizabeth I (1558-1603) and, when it became so, it was the profession of goldsmiths, not merchants. ${ }^{878}$ While Beawes definition of a merchant in 1752 included bankers, ${ }^{879}$ Stevenson (1764) made no such reference ${ }^{880}$ and it is likely that bankers were soon calling themselves such and not merchants. ${ }^{881}$ This is unsurprising since those who established the first banks were, often (besides goldsmiths) lawyers, scriveners and industrialists, not merchants. ${ }^{882}$ The Bank of England, when it was established in 1694, was prevented from being a merchant ${ }^{883}$ and there appears to be have been no legislative (or common law) requirement that a person had to be a 'merchant' in order to operate a bank;

In conclusion, banking was not part of the law merchant as such, since a person who was an insurer or insured did not have to be a merchant.

- $\quad$ Partnership. ${ }^{884}$ In early times, merchants often formed trading associations with respect to sea voyages and exchange. ${ }^{885}$ This was also reflected in the Assizes of Jerusalem and the Laws of Oleron, see 17(e). Further, in medieval times in Italy, it was common for money to be given to a merchant to use in his trade,

\footnotetext{
${ }^{875}$ e.g. p 238 'If the custom exists in one place, it is not thereby extensive to other parts... nor does it usually extend from one case to another...unless it is a question of a custom that is observed in various places, in which case the custom should be observed as a general custom.' Cf. Distinction in early English law between local and general customs.

${ }^{876}$ e.g. p 238 'If the custom exists in one place, it is not thereby extensive to other parts... nor does it usually extend from one case to another...unless it is a question of a custom that is observed in various places, in which case the custom should be observed as a general custom.'

${ }^{877}$ Cunningham, n 693, vol 1, p 147. In Fitz-gerald v Pole (1754) 4 Bro PC 439 (2 ER 297) the House of Lords when speaking of the policy of insurance and the BOE, referred at $\mathrm{p} 444$, to the 'intent of the agreement, the usage of merchants' and 'above all...judicial determinations which are the strongest evidence of the received law of merchants.'

${ }^{878}$ Holdsworth, n 26, vol 8, p 185. See also Rogers, n 12, p 116 et seq. Also, Bewes, n 34, p 57-9.

879 See n 848 and Appendix A.

${ }^{880}$ Stevenson, n 693, p 5 'bankers... are a set of people that reside in trading towns, dealing altogether in money and exchange, and are so called from the Italian word banca, signifying a kind of table or bank; because formerly those who dealt after that manner were accustomed to sit in the public market places with such tables or banks for computing their money and writing their bills of exchange; and because when such dealers had the misfortune of failing in their credit, their tables were broken, either out of contempt, if they were suspected of trading unfairly, or in order to get new ones and be re-established if they were found honest, they were called bankrupts, which name is in use today.'

${ }^{881}$ Davies, n 214, p 288 reflected this with reference to Birmingham's second bank 'founded by Robert Coales around 1770, described in that year's Business Directory as 'Sword-Cutler and Merchant' without even mentioning his banking. By 1789 he was known as 'Banker and Sword Cutler', and by 1797 simply as 'Banker'.

${ }^{882}$ Ibid, 'it was industrialists and transmitters of funds who were the most common sources of bank partnerships, together with lawyers, who, like the London scriveners, had long been accustomed to handling other people's money.' Davies cited LS Pressnell, Country Banking in the Industrial Revolution (1973).

${ }^{883}$ Bank of England Act 1694, s 26 (still extant, present wording) 'to the intent that theire majesties subjects may not be oppressed by the said corporation by theire monopolizing or ingrosseing any sort of goods wares of merchandizes the said corporation to be made and created by this Act shall not att any time dureing the continuance thereof deale or trade or permitt or suffer any person or persons whatsoever either in trust or for the benefitt of the same to deale or trade with any of the stock-moneyes or effects of or any [wise] belonging to the said corporation in the buying or selling of any goods wares or merchandizes whatsoever and every person or persons who shall soe deale or trade or by whose order or directions such dealeings or tradeing shall be made prosecuted or managed shall forfeite for every such dealeing or tradeing and every such order and directions treble the value of the goods and merchandize soe traded for to such person or persons who shall sue for the same by action in the High Court.' See also Holdsworth, n 26, vol 8, p 188.

${ }^{884}$ For early texts see B Montagu, A Digest of the Law of Partnership (London, 1815); W Watson, Law of Partnership (1794). For later texts, see Sweet \& Maxwell, n 320, vol 2. See also Bewes, n 34, ch 7.

${ }^{885}$ As Street noted, n 16, vol 2, p 346 'As may be seen from Van heath $v$ Turner (1622)[see n 737], persons engaged in the business of exchange in this period were not only what we would call correspondents of each other, but actually partners, forming an association or communitas, and liable on each other's contracts.'
} 
with the investor receiving a share of the profits (and bearing loss) - an arrangement called commenda. ${ }^{886}$ Thus, in medieval times, many partnerships were between merchants. However, there seems to have been no legal restriction prohibiting others forming partnerships and this occurred with regard to solicitors, bankers etc. In terms of the law merchant, by 1280 there were two 'privileges' with regard to merchants acting jointly in partnership, as Davies indicated, see 19(a). However, the duty to account became part of the common law and applied generally ${ }^{887}$ while the survivorship rule became of increasing unimportance as the general law on partnership developed; ${ }^{888}$

In conclusion, partnership was linked to the law merchant in early times since many merchants went into partnership, including in respect of sea voyages. However, partnerships were soon entered into by persons other than merchants and, in 1890, the Partnership Act governed matters.

- Charterparties, Bills of Lading \& Stoppage in Transitu. ${ }^{889}$ Although merchants were - from an early time - involved in hiring ships and in shipping goods, there seems to have been no restriction limiting charter parties to merchants alone. ${ }^{890}$

- Bills of Lading. This also applied to bills of lading, a consignor or consignee of goods laded on board ship did not have to be a merchant. ${ }^{891}$ Further, the assignability of bills of lading was accepted early on - doubtless influenced by the position on BOE. ${ }^{892}$ Thus, although maritime matters in this area tended to be associated with the law merchant in early times, this association was to the 'commercial law' in general, rather than to specific aspects of the law merchant; ${ }^{893}$

○ Bills of Sale. Shilton noted that, under maritime custom, a bill of sale was insufficient to transfer title (though it was at common law); physical delivery was necessary. ${ }^{894}$ This custom ended with the Navigation Act 1660 which required the registration of vessels and the transfer of title by way of bill of sale; ${ }^{895}$

- Stoppage in Transit. It was said, by some writers, that stoppage in transit was part of the law merchant. However, the right to stop by an unpaid seller was never restricted only to those who were 'merchants'. Further, the consensus tended to be that such a right was - originally - an equitable right ${ }^{896}$ (an equitable lien), ${ }^{897}$ later recognised by the common law; $;{ }^{898}$

\footnotetext{
${ }^{886}$ Rogers, n 12, p 18.

${ }^{887}$ See now Partnership Act 1890, s 28 'Partners are bound to render true accounts and full information of all things affecting the partnership to any partner or his legal representatives.' See also and Halsbury, Statutes of England and Wales, ( ${ }^{\text {th }}$ ed), vol 79 (partnership), para 135. Rogers, $\mathrm{n} 12, \mathrm{p} 18$ 'Account actions among partners are a particularly good example of how the central courts deliberately adapted the forms of the common law to the needs of commerce.' Montagu (in 1815), n 884, vol 1, p 45 'The action of account has fallen into disuse.' See also FW Maitland, The Forms of Action at Common Law (Cambridge, 1936), pp 63-4.

${ }^{888}$ Montagu, n 884, vol 1, p 162 devoted a footnote to it, stating 'An exception is to be made of joint merchants, for the wares, debts or duties that they have as joint merchants or partners shall not survive, but shall go to the executor of him that deceases, and this is per legem mercatoriam, which... is part of the laws of the realm for the advancement and continuance of commerce and trade, which is pro bono publico for the rule is ius accrescendi inter mercatores pro beneficio commercio locum non habet.'

${ }^{889}$ See generally: (a) WP Bennett, History and Present position of the Bill of Lading as a Document of Title to Goods (1914); (b) E Bensa, The Early History of Bills of Lading (1925). See also Scrutton, n 25, ch 4.

${ }^{890}$ See also texts referred to in $\mathrm{n} 520$. The charterparty itself was civil law version of the indenture. Potts, n 357(charterparty) 'A charter-party is the same in the civil law, as an indenture at common law; and is distinguished from a bill of lading, inasmuch as the former adjusts the term of the freight, and the latter ascertains the contents of the cargo.'

${ }^{891}$ In early times, people physically accompanied their goods (ships were also small). Later, goods placed on board were registered in a ship's register, signed by the captain. Finally, a triplicate bill was issued, when goods were loaded on the ship, both to evidence receipt as well as to comprise a document of title. See Bennett, n 889, pp 6-7.

${ }^{892}$ Evans v Marlett (1697) 1 Ld Raym 271 (91 ER 1078), p 271 per Holt CJ 'the consignee of a bill of lading has such a property as that he may assign it over.'

${ }^{893}$ See generally, Scrutton, $\mathrm{n} 25$, ch 5 .

${ }^{894}$ Shilton, n 250, p xxviii 'The execution of a bill of sale was not...sufficient under the law merchant to transfer the property in a ship. At common law property passed by a sale without physical delivery, but under the law merchant delivery was the essential matter.' She referred to Malynes, $\mathrm{n} 22$ ( $3^{\text {rd }}$ ed, 1686), vol 1, p 123 'the selling of a ship is not sufficient course to alienate the same; but the quiet possession thereof must be delivered upon the sale made.' Cf. When a ship was actually at sea transfer could be effected by execution and delivery of a bill of sale to the extent of enabling the buyer to enter and take possession of the ship on its return to port.'

${ }^{895}$ See 12 Cha 2 c 18 (rep 1825).

${ }^{896} \mathrm{Ibid}$, 'This practice which is founded on principles of justice and equity, was first sanctioned and established in the court of Chancery, and has been subsequently recognised and adopted by a variety of decisions in the courts of law.' See Wiseman v Vandeput (1690) 2 Vern 203 (23 ER 732) 'very allowable to equity.' Cf. Gibson v Carruthers (1841) $8 \mathrm{M} \mathrm{\&} \mathrm{W} 321$ (151 ER 1061) at p 338 per Abinger CB 'In courts of equity
} 
- Liens. The common law recognised certain liens for persons who were obliged to provide a service to the general public viz. common innkeepers, common carriers and common farriers. ${ }^{899}$ Liens were, then, extended to trades. ${ }^{900}$ Liens were not part of the law merchant since lienees were not treated as 'merchants' - save for bankers, when banks commenced in the $17^{\text {th }}$ century. However, bankers were not, generally, treated as merchants by $1729 ;{ }^{901}$

- Bankruptcy. Given the early association of Italians with exchange (the banca), bankruptcy was an act where a merchant became insolvent and his table was overturned. In English law, bankruptcy was reflected in various pieces of legislation which applied to those who 'traded', that is, bought and sold. However, in time, bankruptcy legislation was extended to cover all persons in business; ${ }^{902}$

- $\quad$ Factor. The first English factors were (likely) the agents of English landed gentry. They may also have originated from general agents in the banking field, such as the Italian fattore. ${ }^{903}$ Factors were a species (particular type) of agent. That is, a mercantile (commercial) agent who concentrated on the buying, selling and pledging of goods. ${ }^{904}$ Factors were closely associated with merchants, especially in the agricultural and textile trades and - unlike a broker (who disclosed his agency and did not possess the goods) - they possessed the goods of their principal and presented themselves as the owner. Thus, factors were a species of commercial (mercantile) agent. That is, one who - in the customary course of his business as agent - had his principal's authority to buy and sell goods, as well as to consign (send) them to others for sale and to raise money on them, using them as security. ${ }^{905}$ While closely associated with merchants, however, there seems to have been no restriction of factors only being 'merchants' and, thus, the law on factors applied generally and became progressively statutory, ending with the Factors Act $1889 .{ }^{906}$

Finally, in his criticism, Lord Campbell, in 1849, had declared 'Mercantile questions were so ignorantly treated when they came into Westminster Hall, that they were usually settled by private arbitration among the merchants themselves.' This may be compared with what Davies said in his tract c.1614-21. ${ }^{907}$ One would suggest that both

it has been a received opinion that it was founded on some principle of common law. In the courts of law it is just as much the practice to call it a principle of equity which the common law has adopted.'

${ }^{897}$ Ibid, p 215.'The right of the vendor to stop goods in transitu in case of the insolvency of the vendee is, in the language of Lord Kenyon [in Hodgson v Lay (1797) 7 TR 445 (101 ER 1065) at p 445)], a kind of equitable lien adopted by the law for the purposes of substantial justice, and does not proceed on the ground of rescinding the contract.' See also Smith, $\mathrm{n} 866, \mathrm{p} 679$.

${ }^{898}$ See Abbott, n 591 (in 1802), p 402 'This practice was first sanctioned and established in the Court of Chancery, but has since been frequently recognised and carried into effect by the courts of law.' J Houston, Principles of the Law of Stoppage in Transitu (1886), p 2 'It is difficult to determine the true principle on which the doctrine was established; though first introduced as a purely equitable privilege, it is now considered as a legal possessory right, exercisable for the purposes of justice; and it is consequently favoured and encouraged by courts of law.' Mason v Lickbarrow (1790) $1 \mathrm{H} \mathrm{Bl}$ 364(126 ER 209) per Lord Loughborough at p 363 'I state it be a clear proposition that the vendor of goods not paid for, may retain the possession against the vendee, not by any aid of equity, but on the grounds of law.' Blackburn, n 4 (2nd ed, 1885), p 229 'the right of stoppage in transitu... is now part of the common law.' Stoppage in transit is now statutory, see Sale of Goods Act 1979, ss 44-6.

${ }^{899}$ See generally, GS McBain, Codifying Common Law Liens (2006) 20(4) CLQ 3-47. The common innkeeper was the first, likely, c.1348.

${ }^{900}$ For example, to packers, calico printers, fullers, dyers and bleachers. It was also extended to solicitors and to factors (see $\mathrm{n} 899$ ).

${ }^{901}$ Cf. $n 978$ where Campbell LC indicated that bankers had a general lien recognised in 1749 as part of the law merchant. It would have been more accurate to say that they acquired such a lien by virtue of being a tradesman.

${ }_{902}$ Williams (1812), n 866, p 480 'All persons, whether natural born subjects, aliens, or denizens, being in trade, and capable of making binding contracts, by virtue of the statutes 13 Eliz c 7 s 1 [1571, rep 1825], 1 Jac I c 15 s 2 [1603, rep 1825] and 21 Jac I c 19 s 15 [1623, rep 1825], are liable to the bankrupt laws.' Williams then provided a long list which included 'Any merchant or other person using the trade of merchandise, by way of bargaining, exchange, bartering, cherisance, or otherwise, in gross, or by retail, or seeking his trade of living by buying and selling, is subject to the bankrupt laws.' Cf. cattle drovers, innkeepers, alehouse keepers or victuallers etc were not, in respect of such stock, liable to these laws. Ibid, p 482. See also Bewes, n 34, pp 61-2 'it was not until the year 1861 [24 \& 25 Vict c 134, Bankruptcy Act 1861] that any insolvent debtor other than a trader could be made bankrupt.' See also IF Fletcher, The Law of Insolvency (4 ${ }^{\text {th }}$ ed, 2009),para 1-1017 (following the orthodox view of Holden and Holdsworth, see n 836).

${ }^{903}$ See McBain, $\mathrm{n} 3$ (Codifying Common Law Liens), p 11.

${ }^{904}$ Factors Act $1899 \mathrm{~s} \mathrm{1(1)} \mathrm{'The} \mathrm{expression} \mathrm{'mercantile} \mathrm{agent'} \mathrm{shall} \mathrm{mean} \mathrm{a} \mathrm{mercantile} \mathrm{agent} \mathrm{having} \mathrm{in} \mathrm{the} \mathrm{customary} \mathrm{course} \mathrm{of} \mathrm{his} \mathrm{business} \mathrm{as}$ such agent authority to sell goods, or to consign goods for the purpose of sale, or to buy goods, or to raise money on the security of goods.'

${ }^{905}$ Ibid. Factors soon became a form of banker extending credit to the principal on the security of the goods sent to him. Ibid.

${ }^{906}$ Legislation on factors commenced with 4 Geo IV c 83 (1823, rep 1889). See also Bennett, n 889, pp 25-4 and Scrutton, n 25 , ch 6.

${ }^{907}$ Davies, n 18, pp 16-7 'Until I understood this difference between merchandizes and other goods, and between the law merchant and the common law of England, I confess I do not a little marvel, England being so rich, and entertaining traffic with all the nations of the world, having so many fair ports and so good shipping... what should be the cause that in our books of the common law of England, there are to be found so few cases concerning ships or merchants, or concerning customs or impositions payable for merchandises. But now the reason thereof 
overlooked an absence of legal records as well as a rather vital business point.

- There are (and even more so when Campbell wrote) very few records of fairs' court or of local maritime courts and the HCA records only start c. 1524.Thus, it is wrong to conclude that merchants did not utilize them. They may have done so extensively in early times. As for the king's courts, as Glanvill (c. 1189) noted, the king's courts did not deal with such matters in early times; ${ }^{908}$

- The business point is that the merchant would only have gone to court, anyway, if he could not otherwise settle matters. The latter would have included peer pressure, the support of his guild, ostracism of a defaulter etc. All this would, likely, have achieved as much success (and more cheaply) than going to court. I think that both Campbell and Davies underestimated the fact that, in early times, merchants (acting as a body) would have been fairly formidable. Thus, resort to private arbitration was less to have been due to the ignorance of the common law courts. Rather, it was more on the basis of speed and cost (much as it is today). ${ }^{909}$

In conclusion, by 1760, there was almost nothing of the law merchant left apart from some business practices in the fields of financial law (BOE and promissory notes) and maritime law. ${ }^{910}$

\section{LAW MERCHANT: BLACKSTONE \& MANSFIELD}

Mitchell, in his Essay on the Early History of the Law Merchant (1904), stated:

During the $17^{\text {th }}$ century the decisions of Lord Holt and Lord Mansfield introduced into English common law most of the customs and usages of English merchants, and the law merchant became an integral part of the common law of the realm, and the common law courts practically the only courts where commercial cases were decided...England had by the $17^{\text {th }}$ century already begun to transfer the jurisdiction over commercial cases to the ordinary law courts, and by the $18^{\text {th }}$ century, the process was practically complete. $^{911}$

This opinion (likely based on that of Holdsworth, see 25) reflected the view that the early law merchant was a distinct law; one which became absorbed into the common law.

- However, it is asserted this view is incorrect. It is unsupported by the facts. Also incorrect (it is asserted) is that there was much work to do after 1760. To the contrary, there was precious little left of the 'old' law merchant (that is, privileges accorded to merchants) from 1290 onwards;

- Thus, one would agree with Holden that $90 \%$ of business practices in respect of BOE and promissory notes had become part of the common law (or legislation) by 1710 . The same applied to insurance and maritime matters, where the HCA was in decline (save in respect of prize).

Against this background, it is important to assess the contributions of Mansfield CJ and Blackstone.

(a) Mansfield CJ (1756-88) ${ }^{912}$

Mansfield CJ has been lauded as the 'founder' of commercial law. ${ }^{913}$ However, he built on the foundations of prior judges, such as Hale CJ and Holt CJ. ${ }^{914}$

\footnotetext{
is apparent, for the common law of the land does leave these cases to be ruled by another law, namely the law merchant, which is a branch of the law of nations.' Also cited by Zouch, n 19, p 89.

908 See n 158.

${ }^{909}$ See also Holdsworth, n 26, vol 5, pp 149-50 and pp 152-3.

910 On BOE and promissory notes, one would agree.

${ }^{911}$ Mitchell, n 30, pp 77-8.

${ }^{912}$ See Piergiovanni II, n 41, p 161 et seq, containing a chapter by CP Rodgers, Continental Literature and the Development of the Common Law by the King's Bench: c.1750-1800.' Also, J Oldham, The Mansfield Manuscripts (Univ. of North Carolina Press, 1992).

${ }^{913}$ Lickbarrow v Mason (1787) 2 TR 63 (100 ER 35) per Buller J at p 73, that Mansfield CJ may be truly said to be 'the founder of the commercial law of this country. 'He also noted that, prior to Mansfield CJ, Ibid, p 73'in courts of law all the evidence in mercantile cases was thrown together; they were left generally to a jury, and they produced no established principle.' Holdsworth, n 26, vol 7, p 45 noted Mansfield CJ's Scots legal background, his training in Roman law and his critical analysis, 'These qualities of his mind fitted him admirably for the work of creating and settling the law merchant, which in England was in a backward and unsettled state.' (italics supplied). See also Scrutton, n 188, p 181.

${ }^{914}$ A point noted by Baker I, n 38, pp 1257-8.
} 
- It would also seem clear that Mansfield CJ treated the law merchant as part of English law as he indicated in Edie v East India Co (1761) ${ }^{915}$ and in Pillans v Mierop (1765) ${ }^{916}$ Other judges of the time had a similar opinion; ${ }^{917}$

- Also, like Holt CJ, Mansfield rejected the practices of merchants if he thought that the issue was one of law and not one of fact ${ }^{918}$ or where the matter was already settled by the common law. ${ }^{919}$

Further, while it is often noted that Mansfield referred to a ius gentium in the maritime context - as well as (on relatively few occasions) to foreign maritime laws and legal writers - he cited these foreign laws and writers as persuasive authority only. He was not according them primacy over English law. ${ }^{920}$ Thus, his approach was more consonant with that of his predecessors than might be supposed. Further, Mansfield CJ would have been aware that foreign maritime laws - and foreign writers - often held views contrary to the position under the law of England. Hence, no ius gentium there. An example is a case decided by Mansfield CJ which is often cited as evidence that he believed in a mercantile ius gentium. In Luke v Lyde (or Lloyd)(1759) ${ }^{921}$ - which held that, in event of loss at sea, freight should be paid in proportion to the goods saved and the part of the voyage performed - Mansfield CJ stated:

the maritime law is not the law of a particular country, but the general law of all nations. ${ }^{922}$

Mansfield CJ went on to refer to various foreign maritime laws ${ }^{923}$ as well as writers on the same - such as the Naples jurist, Roccus whose Remarks on Ships and Freight (1655) dealt with the freight payable on goods lost at sea. ${ }^{924}$ Mansfield CJ also referred to English writers on maritime law (Malynes and Molloy) as well to as the laws of Oleron (treated, at that time, as part of English law) ${ }^{925}$ although, curiously, Mansfield failed to cite early English law on jettison. ${ }^{926}$ However, a review of this case often misses out some important details:

\footnotetext{
9152 Burr 1216 (97 ER 797) at pp 1222 \& 1224. See also Baker II, n 38, p 1275.

${ }_{916}$ Pillans $v$ Van Mierop (1765) 3 Burr 1663 (97 ER 1035) per Mansfield CJ at p 1669: 'The law of merchants, and the law of the land, is the same: a witness cannot be admitted to prove the law of merchants; we must consider it as a point of law.' See also Rogers, n 12, p 222 and Baker II, n 38, p 1275. Cranch, n 16, vol 3 p 74 'it [the law merchant] ought not to be considered as a system contrary to the common law, but as an essential constituent part of it.'

${ }^{917}$ Edie v East India Co (1761)(see n 915 at p 1226 per Foster J ' But the custom of merchants, or law of merchants, is the law of the kingdom; and is part of the common law... This custom of merchants is the general law of the kingdom, part of the common law, and therefore ought not to have been left to a jury after it had been already settled by judicial determinations.' Ibid, per Wilmot J, at p 1227 'The custom of merchants is part of the law of England; and the courts of law must take notice of it as such.' Ibid, $p 1228$ 'these judicial determinations of the point are the lex mercatoria, as to this question: for they settle what is the custom of merchants; which custom is the lex mercatoria, which is part of the law of the land.'.

${ }^{918}$ Grant v Vaughan (1764) 3 Burr 1516 (97 ER 957). A special jury held that a cheque payable to bearer was not negotiable. Mansfield CJ rejected this, p 1523 'for it is a question of law 'whether a bill or note be negotiable. , or not' It appears in the books that these notes [cheques to bearer] are by law, negotiable.' For other cases where the courts granted new trials when dissatisfied with jury findings, see Rogers, $n 12, \mathrm{p}$ 212. See also Coquillette, n 13, pp 291-2.

${ }^{919}$ Edie v East India Co (1761) 2 Burr 1216 (97 ER 797), p 1222 'I ought not to have admitted any evidence of the particular usage of merchants in such a case...for the law is already settled.' See also Holden, n 375, pp 118-9.

${ }^{920}$ See the charge by the author of Junius against him, 'In contempt or ignorance of the common law of England, you have made it your study to introduce into the court where you preside, maxims of jurisprudence unknown to Englishmen. The Roman code, the law of nations, and the opinions of foreign civilians, are your perpetual theme.' Cf. Scrutton, n 188, p 180 'in no instance did he [Mansfield] ever attempt to substitute Roman rules and maxims for those of the common law.' See also Campbell, n 851, vol 2, p 437.

9212 Burr 882 (97 ER 614).

${ }_{922}$ Ibid, p 887. In this judgment, Mansfield CJ, at p 887 quoted Cicero (see n 767). This was mis-quoted by Scrutton, n 25, p 6 as 'Mercantile law is not the law of a particular country, but the law of all nations', a point noted by Rogers, n 12, p 168, fn 46.

${ }_{923}$ Mansfield CJ referred to: (a) Rhodian law; (b) the Consolato del Mare; (c) laws of Oleron (taken from Usages and Customs of the Sea); (d) Hanseatic laws, including those of Wisby; (e) Ordinance of Louis XIV of 1681. See 17(f). See also Cunningham (pub 1760), n 693, vol 1, pp 321-5.

${ }^{924}$ Roccus, $\mathrm{n} 674$. He divided his text into articles ('notes'). In note 81 (see Ingersoll's trans, p 71) he stated: 'When a part of the goods and the ship are lost, and another part is recovered and saved, freight is payable in proportion to the quantity of goods saved, and according to the portion of the voyage performed up to the place where the loss happened'. Roccus cited for this proposition the Spanish jurist, Juan de Hevia Bolano, his Curia Philipica (1615, facsimile ed 1797, pub. Lex Nova, 1989), a text on commercial and maritime law. However, this principle may be traced to the laws of Oleron (which the Consolato del Mare reflected) and, prior to that, the Rhodian law (which the Digest of Justinian reflected).

${ }^{925}$ See 17(e).

${ }^{926}$ The Laws of William I (c. 1070), see Robertson, n 52, p 269 made provision on jettison which, as Twiss noted, accorded not with Roman law but 'with a more modern usage, such as we find subsequently reduced into writing in the Rolls of Oleron.' See also Shomberg (he was a fellow of Magdalen College, Oxford), n 638, p 60 (the law of William I was made 'in imitation of the ancient Rhodian law'). Shomberg also referred to the Rolls of Oleron, arts 8-10.
} 
- Roccus himself referred to other texts (including Justinian's Digest and the Consolato del Mare) as persuasive authority. ${ }^{927}$ Thus, Mansfield CJ was not treating Roccus as stating the law per se, nor his view as being conclusive of the matter;

- Further, various statements of Roccus in his text clearly conflicted with English law, which (likely) Mansfield would have been aware of;

- For example, Roccus asserted that a master of a ship might be compelled to carry goods and passengers for the public good, similar to an innkeeper who might be compelled to receive guests. ${ }^{928}$ However, a common (public) carrier under English common law was only compelled to carry: (a) goods (not passengers); (b) when he held himself out as carrying for the public; and (c) in limited circumstances. 929 And, a common (public) innkeeper was only compelled to entertain guests when holding himself out as such - and only in limited circumstances. ${ }^{930}$

Thus, there is no evidence that Mansfield CJ would have supported Roccus on these points ${ }^{931}$ - which also indicate there was no ius gentium of which English law was part, in respect of the same. Indeed, a review of the decisions of Mansfield $\mathrm{CJ}$ in the maritime, insurance and financial fields (when he dealt with BOE and promissory notes) indicate that his references to foreign laws (and writers) were relatively few and that he was citing these as persuasive authority rather than as be part of a ius gentium which must, thereby, being applied to English law as well.

In conclusion, Mansfield CJ adhered to the view (since 1280, see 8) that the law merchant was part of, not distinct from, English law. Further, the courts controlled the process of receiving business practices (customs of merchants) into the common law. There was no obligation to apply them automatically.

\section{(b) Blackstone (1765-9)}

Blackstone, in his Commentaries on the Laws of England (1769), noted the protection given to foreign merchants and to trade. ${ }^{932}$ He also referred to the ius gentium. ${ }^{933}$ and stated that:

in mercantile questions, such as bills of exchange and the like; in all marine causes, relating to freight, average, demurrage, insurances, bottomry, and others of a similar nature; the law merchant, which is a branch of the law of nations, is regularly and constantly adhered to. So too in all disputes relating to

\footnotetext{
${ }^{927}$ Ibid, p 131 'The custom of merchants is to be respected in marine insurances. When the practice and observance of merchants are notorious, any good proof of them should be admitted.' Ibid, p 139 'subjects of insurance and disputes relative to ships are to be decided according to maritime law; and the usages and customs of the sea are to be respected. The proceedings are to be according to the forms of maritime courts and the rules and principles laid down in [the Consolato del Mare], in which every thing relating to these subjects is to be found, and it is always considered a guide in these disputes.' Ibid, p 17 'Shipping and navigation, are of the greatest importance and utility to mankind. Our object in these notes is to explain the general rules and principles of law, by which they are regulated.'

${ }^{928}$ For example, Roccus stated (see Ingersoll, n 674, p 22) 'A master of a ship may be compelled to sail with his ship and to carry goods, passengers and sailors, and to make any ordinary voyage, because the public good requires it, and the public have a right to the use of ships. So widely is this principle extended that if a person endeavour to excuse his ship from public use, it will be confiscated. Another reason for this principle is, that the owner or master of a ship is considered in the light of an innkeeper, who, after opening his house and undertaking to entertain, may be compelled regularly to receive guests.' Roccus referred to the Digest, n 642, bk 11, title 3, 'De Navibus.'

${ }_{929}$ See McBain, n 3 (Common Carrier), pp 545-96. Further, the liability of the common carrier to carry - as well as his strict liability in respect of carriage - derives from the common law, not Roman law. See Ibid, p 556 citing Nugent $v$ Smith (1876) 1 CPD 423, 430 (re strict liability) and p 563, citing Rushforth $v$ Hadfield (1806) 6 East 519 (102 ER 1386) per Ellenborough CJ at p 525 'by the custom of the realm a common carrier is bound to carry the goods of the subject for a reasonable reward.' See also Lane v Cotton (1701) 12 Mod 472 (88 ER 1458), per Holt CJ (public policy requirement).

${ }^{930}$ See McBain, $n 3$ (Liability of Hotelkeepers), pp 705-55. Also, McBain, n 3 (Common Carrier), p 557.

931 Thus, in Forward v Pittard (1785) 1 TR 27 (99 ER 953) (a case concerning a common carrier) there is no evidence that Mansfield CJ regarded the strict liability of the same as deriving from Roman law. Rather, following Coggs v Barnard (1703) 2 Ld Raym 909, per Holt CJ, he took it as a policy of the common law. And for an obligation to carry see, there is no evidence that Mansfield CJ would not have followed Holt CJ in Lane v Cotton (1701), see n 929. See also McBain, n 3 (Common Carrier), p 558.

932 Blackstone, n 186, vol 1, pp 252-3.

${ }^{933}$ Ibid, vol 4, p 67 'The law of nations is a system of rules, deducible by natural reason, and established by universal consent among the civilized inhabitants of the world, in order to decide all disputes, to regulate all ceremonies and civilities, and to insure the observance of justice and good faith, in that intercourse which must frequently occur between two or more independent states, and the individuals belonging to each...' Ibid, p 67 'In arbitrary states this law, wherever it contradicts or is not provided for by the municipal law of the country, is enforced by the royal power: but since in England no royal power can introduce a new law, or suspend the execution of the old, therefore the law of nations (wherever any question arises which is properly the object of its jurisdiction) is here adopted in its full extent by the common law, and is held to be part of the law of the land. And those acts of Parliament, which have from time to time been made to enforce this universal law, or to facilitate the execution of its decisions, are not to be considered as introductive of any new rule, but merely as declaratory of the old fundamental constitutions of the kingdom; without which it must cease to be a part of the civilized world.'
} 
prizes, to shipwrecks, to hostages, and ransom bills, there is no other rule of decision but this great universal law, collected from history and usage, and such writers of all nations and languages as are generally approved and allowed of. ${ }^{934}$ (italics supplied)

Blackstone cited no authority for this proposition - although he was likely influenced by Malynes and Molloy. ${ }^{935}$ As to the law merchant, Blackstone made it clear that it was part of the common law, stating:

as the transactions of foreign trade are carried on between subjects of independent states, the municipal laws of one will not be regarded by the other. The affairs of commerce are regulated by a law of their own called the law merchant or lex mercatoria, which all nations agree in and take notice of, and it is particularly held to be part of the law of England which decides the causes of merchants by the general rules which obtain in all commercial countries, and that often even in matters relating to domestic trade, as for instance, in the drawing, the acceptance, and the transfer of bills of exchange. ${ }^{936}$ (italics supplied)

More particularly, Blackstone considered custom which was part of the common law, including special (particular) customs. ${ }^{937}$ In respect of the latter, he referred to the customs of London and of merchants stating:

particular customs within the city of London, with regard to trade, apprentices, widows, orphans, and a variety of other matters; which are all contrary to the general law of the land, and are good only by special custom, though those of London are also confirmed by act of parliament. To this head may most properly be referred a particular system of customs used only among one set of the king's subjects, called the custom of merchants or lex mercatoria; which, however different from the common law, is allowed for the benefit of trade, to be of the utmost validity in all commercial transactions; the maxim of law being, that 'cuilibet in sua arte credendum est. ${ }^{, 938}$ [a person skilled in his art is to be believed]

With regard to both London customs and those of merchants, the method of proving them differed. London customs could be certified by the recorder. ${ }^{939}$ However, for customs of merchants - as with other customs (save for gavelkind and borough-English) ${ }^{940}$ - it was pleaded before a jury unless the custom had been previously upheld. ${ }^{941}$ When proved to exist, it had to be a 'good' custom, thus, it must:

(a) have been used so long, that memory of man ran not to the contrary; ${ }^{942}$

(b) have been continuous; 943

(c) be peaceable and acquiesced in; 944

(d) not be unreasonable; ${ }^{945}$

\footnotetext{
934 Blackstone, n 186, vol 4, p 67.

${ }^{935}$ See also Jacob, $\mathrm{n} 847$ (in 1729) definition of Law Merchant (Lex Mercatoria)' Is a special law differing from the common law of England, proper to merchants, and become a part of the law of England.' See also G Jacob, Lex Mercatoria or the Merchant's Companion ( $\left(1^{\text {st }}\right.$ ed, 1729), p 23 'The law merchant (so called from its universal concern) all nations take special knowledge of, and the common and statute laws of England, leave the causes of merchants, in many cases, to their own peculiar law.'

${ }^{936}$ Blackstone, n 186, vol 1, pp 263-4.

${ }^{937}$ Ibid, p 63 'The lex non scripta, or unwritten law, includes not only general customs, or the common law properly so called; but also the particular customs of certain parts of the kingdom; and likewise those particular laws, that are by custom observed only in certain courts and jurisdictions.'

${ }_{938}$ Ibid, p 75. Blackstone followed Coke, n 16, vol 1, 125 ('cuilibet in sua arte perito est credendum').

${ }^{939}$ Ibid, p 76 'The customs of London differ from all others in point of trial: for, if the existence of the custom be brought in question, it shall not be tried by a jury, but by certificate from the lord mayor and aldermen by the mouth of their recorder; unless it be such a custom as the corporation is itself interested in, as a right of taking toll, etc, for then the law permits them not to certify on their own behalf.'

${ }^{940}$ Ibid. 'As to gavelkind and borough-English, the law takes particular notice of them; and there is no occasion to prove that such customs actually exist, but only that the lands in question are subject thereto.'

${ }^{941}$ Ibid. 'All other private customs must be particularly pleaded, and as well the existence of such customs must be shown, as that the thing in dispute is within the custom alleged...The trial... is by a jury of twelve men, and not by the judges, except the same particular custom has been tried, determined, and recorded in the same court.'

${ }^{942} \mathrm{Ibid}$, 'That it have been used so long, that the memory of man runneth not to the contrary. So that if any one can show the beginning of it, it is no good custom.'

${ }^{943}$ Ibid, p 77 'It must have been continued [continuous]. Any interruption would cause a temporary ceasing: the revival gives it a new beginning, which would be within the time of memory, and thereupon the custom will be void.'

${ }^{944}$ Ibid, 'It must have been peaceable, and acquiesced in; not subject to contention and dispute. For as customs owe their origin to common consent, their being immemorially disputed either at law or otherwise is proof that such consent was wanting.'

${ }^{945}$ Ibid. 'Customs must be reasonable; or rather, taken negatively, they must not be unreasonable. Which is not always, as sir Edward Coke says, to be understood of every unlearned man's reason, but of artificial and legal reason, warranted by authority of law.'
} 
(e) be certain;

(f) be compulsory;

(g) be consistent with other customs.

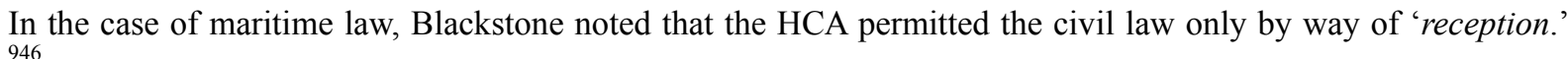

\section{(c) $\underline{\text { Conclusion }}$}

There is no doubt of the great contribution of Mansfield CJ to commercial law. However, in respect of the law merchant, he was at the 'tail end' of things since the 'old' law merchant had gone and BOE's and promissory notes had long been in common use; they could be sued on by anyone and not just 'merchants' for nearly a hundred years (c.1692). ${ }^{947}$ Further, there was nothing unorthodox about Mansfield's approach vis-à-vis the court accepting business practices and, thereby, making them part of the common law. His great skill was, perhaps, in giving much more attention to the jury - as well as to the benefits of commercial law - than some of his predecessors.

\section{Given then, that the law merchant was almost over by 1788 , when did it die?}

\section{DECLINE OF THE LAW MERCHANT}

\section{(a) Period 1802-1834}

In 1802, Abbott published the first edition of his celebrated treatise on the Law relative to Merchant Ships and Seamen. ${ }^{948}$ It may be seen as helping create a separate branch of law - maritime law - just as Park had done with his text in 1787 on insurance. ${ }^{949}$ Abbott noted that his was the first text on maritime law by an English lawyer since Molloy (in 1676 with editions until 1788). ${ }^{950}$ Although Abbott quoted foreign maritime laws and lawyers, ${ }^{951}$ he emphasized that this was for illustrative purposes only. ${ }^{952}$ As for other texts in this period:

- Montefiore, Commercial Dictionary (1803), referred to the law merchant. ${ }^{953} \mathrm{He}$ also noted that retailers were no longer called 'merchants'; ${ }^{954}$

- There were texts on commercial law by Williams (1812) ${ }^{955}$ and Woolrych (1829), ${ }^{956}$ both of which made scant reference to the law merchant. Apart from some early texts on contract, ${ }^{957}$ in 1834 , there was a commercial dictionary by McCulloch ${ }^{958}$ as well as a text by Chitty. ${ }^{959}$

\footnotetext{
${ }^{946} \mathrm{Ibid}, \mathrm{vol}$ 3, p 108 'The proceedings of the courts of admiralty bear much resemblance to those of the civil law, but are not entirely founded thereon; and they likewise adopt and make use of other laws, as occasion requires, such as the Rhodian laws, and the laws of Oleron. For the law of England... does not acknowledge or pay any deference to the civil law considered as such, but merely permits its use in such cases where it judges its determination equitable, and therefore blends it, in the present instance, with other marine laws: the whole being corrected, altered and amended by acts of Parliament, and common usage; so that out of this composition, a body of jurisprudence is extracted, which owes its authority only to its reception here by the consent of the Crown and people.' (italics supplied)

${ }^{947}$ See $\mathrm{n} 723$.

948 See n 591.

949 See Park, n 861 .

${ }^{950}$ Abbott, $\mathrm{n}$ 591, p iii 'It is now more than a century since the first publication of the work of Molloy, the only English lawyer, who has written on these matters... Yet the absence of a general and established code of maritime law, which almost every other European nation possesses, seems to render a collection of the principal points of that law peculiarly necessary both for English merchants and English lawyers.'

951 Ibid. Preface. Abbott quoted (a) laws of Oleron; (b) laws of Visby; (c) Ordinances of the Hanse towns (1597 \& 1614); (d) Ordinance of Louis XIV 1681 (with commentary by Valin), as well as to writers such as Roccus, Pothier and Emerigon.

${ }_{952}$ Ibid, p vii 'not only of all these treatises, but also of the civil law, and the Ordinances... have not the binding force or authority of law in this country; and that they are here quoted, sometimes to illustrate principles generally admitted and received; sometimes to show the opinion of learned persons, and the rule adopted in maritime nations upon points not hitherto settled by the authority of our own law; and at other times to furnish information, that may be useful in our commercial intercourse with foreign states.'

${ }_{953}$ Montefiore, n 559 (1803)(law merchant), 'Law merchant, is a system of customs acknowledged and taken notice of by all commercial nations, and these customs constitute a part of the general law of the land; and being part of that law, their existence cannot be proved by witnesses, but the judges are bound to take notice of them ex officio. These customs are of the highest validity in all commercial circles.'

${ }^{954}$ Ibid. '(merchant) 'a person who buys and sells commodities in the gross, or who traffics commercially by exporting or importing for his own account. The word was formerly of a different meaning in this country from what it is now; retail dealers were then called merchants, as they are in France and Holland still; but in this country those who sell retail, with a few exceptions, have lost that appellation. The transacting mercantile business does not constitute a merchant. Those who buy, sell, export, and import for the account and at the risk of others, are called agents, factors, and bankers. Those who transact business, by keeping goods ready in their possession, are termed warehousemen, though they do not sell by retail; yet, in some cases, those who do deal in retail transactions, such as coal merchants, wine merchants, hop merchants, timber merchants, etc etc are honoured with that appellation.'
} 


\section{(b) Smith - Compendium of Mercantile Law (1834)}

An important work in this era was Smith, Compendium of Mercantile Law (1834), ${ }^{960}$ since his introduction (I quote from the $3^{\text {rd }}$ ed in 1885) influenced other writers such as MacDonell and Scrutton. According to Smith, the English law merchant, mainly, derived from Roman law as well as from European maritime codes; ${ }^{961}$ Despite this, and somewhat inconsistently, Smith indicated that such sources were illustrative only ${ }^{962}$ stating:

the foreign laws and foreign lawyers, who have been just mentioned ${ }^{963}$ as having influenced the formation of the mercantile law of this country, were never, at any period, recognized by the judges of our courts as being, per se, of any authority whatsoever. Respected the rules which they lay down may be for the learning and sagacity which they evince, but, when they are obeyed, it is as part of the law and custom of England, declared to be such, either by long usage and tradition, or by the decisions of our own courts of justice containing an enlightened adaptation of ancient principle to modern convenience. $^{964}$

Smith also declared that:

The mercantile law of England is, in point of fact, an edifice erected by the merchant, with comparatively little assistance either from the courts or legislature. The former have, in very many instances, only impressed with a judicial sanction, or deduced proper and reasonable consequences from, those regulations which the experience of the trader, whether borrowing from foreigners or inventing himself, had already adopted as the most convenient. ${ }^{965}$

Despite this analysis, in his text, ${ }^{966}$ Smith made almost no reference to the 'merchant' - referring, instead, to the more generic concept of a trader. ${ }^{967}$ He made even less reference to the law merchant, reflecting the (almost total) demise of the latter.

\footnotetext{
${ }^{955}$ Williams, n 866. His text was, really, the first, modern style, text on commercial law, gathering together disparate works on maritime law, insurance, bankruptcy, BOE etc, see $\mathrm{p}$ viiii.

${ }^{956}$ HW Woolrych, Commercial and Mercantile Law of England (1829). Although he analysed a wide range of what was then commercial law viz (a) shipping; (b) insurance; (c) contacts; (d) liens; (e) bonds; (f) BOE and promissory notes; (g) bankruptcy and insolvency, he did not discuss the law merchant and he used the term 'merchant' in a general sense.

${ }^{957}$ See (a) S Comyn, Law of Contracts and Agreements not under Seal ( $1^{\text {st }}$ ed, 1807); (b) HT Colebrooke, Treatise on Obligations and Contracts. Pt 1 (1818); (c) J Newland, Contracts within the jurisdiction of Courts of Equity (1806).

${ }^{958}$ McCulloch, see n $396\left(1^{\text {st }}\right.$ ed, $1834,3^{\text {rd }}$ ed, 1856).

${ }^{959}$ E Chitty, The Commercial and General Lawyer ( $1^{\text {st }} \mathrm{ed}, 1834-6 ; 2^{\text {nd }}$ ed, 1840). He made no mention of 'merchant' or 'law merchant.' See also S Clarke \& J Williams, The Cyclopaedia of Commerce (1819) and J Chitty (jun), Law of Contracts $\left(1^{\text {st }}\right.$ ed, 1826; 21 $1^{\text {st }}$ ed, 1955).

${ }^{960}$ Smith, n 866 (1st ed,1834; $13^{\text {th }}$ ed, 1931). I quote from the $3^{\text {rd }}$ ed (1855).

${ }^{961}$ Ibid, p 18 'As the mercantile law of England contains a great variety of interests and possessions, so it is derived from a variety of sources and authorities. In ascertaining the legal rights arising out of commercial transactions, it frequently becomes necessary to have recourse to the volumes of international law, frequently to the contemporaneous laws of nations ... It is deducible in great part from the different maritime codes of ancient Europe; and all these, its components, while they are interspersed and qualified by a multiplicity of statutory enactments, are explained, blended, and applied, and the cases for which they have omitted to provide are solved, by the English courts of law or equity.' Cf. De la Chaumette v Bank of England (1831) 2 B \& Ad 385 (109 ER 1186) per Tenterden CJ at p 389 'the custom of merchants, which was part of the common law introduced into this country, in consequence of the practice in other countries.' See also Baker II, n 38, p 1266.

962 Ibid, p 23.

${ }^{963}$ Smith referred to maritime laws such as Rhodian law, Consolato del Mare, Ordinance of Visby, Hanseatic Ordinances and the Laws of Oleron, as well as French legal writers such as Valin, Pothier and Emerigon.

${ }^{964}$ Smith, n 866, p 23.

${ }^{965}$ Ibid, p 29. Ibid, p 24 'It is under the action of assumpsit that the modern law merchant has been incorporated into the common law. In the time of Edward III [1327-77] we discover, that in the ordinary transactions amongst merchants, that is, members of the trading community, a distinct law prevailed, of a more liberal nature than the general law, and that it was more summarily and expeditiously exercised. This was called the lex mercatoria: it had, in all probability, silently prevailed in London, and other commercial towns, in some shape, throughout the whole of the Anglo-Saxon times.'

${ }^{966}$ Smith analysed the law on: partners, companies, agency, shipping, bills of exchange and promissory notes, insurance, contracts of employment (including those of apprentices and seamen), guarantees, contracts of sale, debt, stoppage in transit and liens. Those in italics are now viewed as discrete fields of law.

${ }^{967}$ Smith, n 866, p 37 'Trade may be carried on by individuals, partnerships, or companies, corporations, and their respective agents...The word trader is used in the bankrupt laws in a definite and peculiar sense. For the general purposes of law it seems to have a wider signification that is either there, or in common parlance of mankind, attributed to it; and, perhaps, it is not going too far to say, that every man who does an act upon which any of the rules of law operate becomes, quoad that act, a trader, though his ordinary pursuits may not be of a mercantile character.'
} 


\section{(c) Period 1834-1882}

From 1834-82, there were some more texts on commercial law ${ }^{968}$ as well as on contract. ${ }^{969}$ However, in terms of the law merchant, they added nothing to what had been previously stated, save that Blackburn - in his text, Contract of Sale (1845) - adverted to the obscurity of the law merchant as a concept. ${ }^{970}$ There were some important Victorian cases, though, which deprecated the law merchant being part of a ius gentium or a distinct field of law. Thus:

- No Ius Gentium. In Lloyd v Guibert (1865) ${ }^{971}$ Willes J, delivering the judgment of the Exchequer Chamber, expressed scepticism about any ius gentium; ${ }^{972}$

- Law Merchant. In Crouch v Credit Foncier of England (1873), Blackburn J noted that the law merchant was part of English law, ${ }^{973}$ as did Bigham J in Edelstein $v$ Schuler \& Co (1902)..$^{974}$

In Goodwin v Robarts (1875) ${ }^{975}$ - a case on the negotiability of certain foreign scrip - Cockburn CJ made an important statement in respect of the law merchant. Rejecting an argument that mercantile usage had to be of considerable age before it would be accepted by the English courts, ${ }^{976}$ he also stated that the law merchant:

is neither more nor less than the usages of merchants and traders in the different departments of trade, ratified by the decisions of courts of law, which, upon such usages being proved before them, have adopted them as settled law with a view to the interests of trade and the public convenience, the court proceeding herein on the well-known principle of law that, with reference to transactions in the different departments of trade, courts of law, in giving effect to the contracts and dealings of the parties, will assume that the latter have dealt with one another on the footing of any custom or usage prevailing generally in the particular department. By this process, what before was usage only, unsanctioned by legal decision, has become engrafted upon, or incorporated into, the common law, and may thus be said to form part of it. ${ }^{977}$

Thus, Cockburn CJ emphasized that the customs (business practices or usages) of merchants were not, in themselves, law; they only became so when accepted by the courts - a point which had also been made by Campbell LC in Brandao v Barnett (1849). ${ }^{978}$

\footnotetext{
968 See: (a) L Levi, Manual of the Mercantile Law of Great Britain and Ireland ( $1^{\text {st }}$ ed, 1854); (b) G Stephen, Principles of Commerce and Commercial Law ( $1^{\text {st }}$ ed, 1853); (c) R Campbell, Law relating to the Sale of Goods and Commercial Agency (1 $1^{\text {st }}$ ed, 1881); (d) G Willmore \& E Bedell, Mercantile and Maritime Guide (1 ${ }^{\text {st }}$ ed, 1856); (e) RV Campbell, Principles of Mercantile Law (1 $1^{\text {st }}$ ed, 1890).

${ }^{969}$ See: (a) CG Addison, Law of Contracts (1st ed, 1845-7); (b) W Anson, Principles of the Law of Contracts (1 ${ }^{\text {st }}$ ed, 1879); (c) WE Ball, Principles of Torts and Contracts ( $1^{\text {st }}$ ed, 1880); (d) CCM Plumptre, Law of Simple Contracts ( $1^{\text {st }}$ ed, 1879); (e) F Pollock, Principles of Contract $\left(1^{\text {st }}\right.$ ed, 1876; $13^{\text {th }}$ ed, 1950); (f) A Shearwood, Law of Contract $\left(1^{\text {st }}\right.$ ed, 1879).

${ }^{970}$ See $\mathrm{n} 4$ ( $2^{\text {nd }}$ ed, 1885). See also Baker I, n 38, p 1233 and MacDonell, n 375, p lxiii.

${ }^{971}$ LR 1 QB 115. See also The Gaetano and Maria (1882), per Brett LJ, see n 685.

${ }^{972}$ With respect to the contention that a contract of affreightment ought to be construed with reference to 'the general maritime law', Willes $\mathrm{J}$ stated, pp 123-5, 'We can understand this term in the sense of the general maritime law as administered in the English courts, that being in truth nothing more than English law, though dealt out in somewhat different measures in the common law and chancery courts, and in the peculiar jurisdiction of the admiralty ... it would be difficult to maintain that there is....any general in the sense of universal law, binding at sea, any more than upon land ...In truth any general, much more any universal, maritime law, binding upon all nations using the highway of the sea in time of peace, except when limited as administered in some court, is easier longed for than found.'

973 (1873) LR 8 QB 374. See also Baker II, n 38, p 1266.

${ }^{974}$ [1902] 2 KB 144, at p 155 'our common law, of which the law merchant is but a branch.'

975 (1875) LR 10 Ex 337. The decision of the House of Lords ((1875) LR 10 Ex 337 at 346 was not very satisfactory. See Baker II, n $38, \mathrm{p} 1281$ and FA Bosanquet, Law Merchant and Transferable Debentures (1899) 15 LQR 130-44. Cf. FB Palmer, The Negotiability of Debentures to Bearer and the Law Merchant, Ibid, pp 245-58.

${ }^{976} \mathrm{Ibid}, \mathrm{p} 346$ 'It is founded on the view that the law merchant thus referred to is fixed and stereotyped, and incapable of being expanded and enlarged so as to meet the wants and requirements of trade in the varying circumstances of commerce. It is true that the law merchant is sometimes spoken of as a fixed body of law, forming part of the common law, as it were coeval with it. But as a matter of legal history, this view is altogether incorrect. The law merchant thus spoken of with reference to bills of exchange and other negotiable securities, though forming part of the general body of the lex mercatoria, is of comparatively recent origin.' See also Bechuanaland Exploration Co v London Trading Bank [1898] 2 QB 658 (usage originating within the memory of living persons can operate to create a valid custom under the principles of the law merchant). Also, Edelstein v Schuler \& Co (1902) 2 KB 144 per Bigham J 'it is to be remembered that in these days usage is established much more quickly than it was in days gone by; more depends on the number of transactions which helped to create it than on the time over which the transactions are spread.'

977 Ibid, p 346.

978 Ibid. Cockburn CJ quoted Campbell LC in Brandao v Barnett (1849) $12 \mathrm{Cl} \& \mathrm{~F}$ (8 ER 787) (it dealt with a bankers' general lien), at p 805 'The usage of trade by which bankers are entitled to a general lien, is not found by the special verdict, and unless we are to take judicial notice of it, the plaintiff is at once entitled to judgment. But, my lords, I am of opinion that the general lien of bankers is part of the law
} 
In conclusion, the Victorian courts emphasized that the law merchant was part of English law. Also, that it was not part of any ius gentium.

\section{BILLS OF EXCHANGE ACT 1882 \& OTHER LEGISLATION}

The Bills of Exchange Act 1882 codified the law relating to bills of exchange, cheques and promissory notes. It is still with us. ${ }^{979}$ It was drafted by Sir McKenzie Chalmers and its purpose was to consolidate all extant common law (including the law merchant) on the matter. ${ }^{980}$ It made only one reference to the law merchant, $\mathrm{s}$ 97(2) stating:

The rules of common law including the law merchant, ${ }^{981}$ save in so far as they are inconsistent with the express provisions of this Act, shall continue to apply to bills of exchange, promissory notes, and cheques. (italics supplied)

This section put beyond doubt - in the context of BOE and promissory notes - that the law merchant was part of the common law since it used the word 'including.' However, was this saving necessary? It seems that it was made ex abundante cautela and, indeed, there appear to have been no cases on s 97(2) with reference to the law merchant since $1882 .{ }^{982}$ Two other pieces of legislation referred to the law merchant:

- Marine Insurance Act 1906. Chalmers adopted the same process of reference to the law merchant in the Marine Insurance Act 1906, s 91(2). ${ }^{983}$ As with the Bills of Exchange Act 1982, there appear to be no subsequent cases relating to it; ${ }^{984}$

- $\quad$ Sale of Goods Act 1893. The Sale of Goods Act 1893, s 61 contained a similar provision on the law merchant ${ }^{985}$ one now contained in the Sale of Goods Act 1979, s 62. ${ }^{986}$ There also appear to have been no cases with reference to the law merchant. ${ }^{987}$

These three Acts appear to be the only legislation remaining that refers to the 'law merchant'. If such words were deleted, it would have no effect since reference to the common law remains (including any law merchant).

In conclusion, these three pieces of legislation refer to the law merchant. However, such are not required and can be deleted today.

\section{THE STRANGE DEATH OF THE LAW MERCHANT: 1898}

There were a few legal texts on mercantile law in the period 1882-98, but they added nothing to what has been

merchant, and is to be judicially noticed - like the negotiability of bills of exchange, or the days of grace allowed for their payment. When a general usage has been judicially obtained and established, it becomes a part of the law merchant, which courts of justice are bound to know and recognize. Such has been the invariable understanding and practice in Westminster Hall for a great many years; there is no decision or dictum to the contrary, and justice would not be administered if evidence were required to be given toties quoties to support such usages, and issue might be joined upon them in each particular case.' Ibid, p 810 'There is no question that, by the law merchant, a banker has a general lien for his general balance on securities deposited with him.'

${ }^{979}$ For texts on BOE and promissory notes from 1800-1950, see Sweet \& Maxwell, n 320, vol 2. For modern texts see: (a) D Richardson, $A$ Guide to Negotiable Instruments ( $7^{\text {th }}$ ed, 1983); (b) AG Guest (ed), Chalmers \& Guest on Bills of Exchange, Cheques and Promissory Notes (1 ${ }^{\text {st }}$ ed, 1878; $17^{\text {th }}$ ed, 2009); (c) N Elliott et al (ed), Byles on Bills of Exchange and Cheques (29 ${ }^{\text {th }}$ ed, 2013); (d) W Hedley, Bills of Exchange and Bankers Documentary Credits ( $4^{\text {th }}$ ed, 2001); (e) H Beale (ed), Chitty on Contracts (32 ${ }^{\text {th }}$ ed, 2015).

${ }^{980}$ Chalmers analysed this Act in two texts, see e.g. M Chalmers, The Bills of Exchange Act 1882, with explanatory Notes $\left(7^{\text {th }}\right.$ ed, 1892) and M Chambers' Digest of the Law of Bills of Exchange ( $4^{\text {th }}$ ed , 1891). See also MD Chalmers, Codification of Mercantile Law (1903) LQR 10-18.

${ }^{981}$ A M'Neil, Bills of Exchange, Cheques and Promissory Notes ( $\left.3^{\text {rd }} \mathrm{ed}, 1920\right), \mathrm{p} 95$ 'By the term 'law merchant' is meant the usages of merchants and traders in the different departments of commerce, ratified by the decisions of courts of law, which upon such usages being proved before them, have adopted them as settled law, with a view to the interests of trade and the public convenience.'

${ }_{982}$ Halsbury, Statutes of England and Wales ( $5^{\text {th }} \mathrm{ed}$ ), vol 19(1), does not refer to any; nor do the texts cited in $\mathrm{n} 979$.

${ }^{983}$ It provides: 'The rules of common law including the law merchant, save in so far as they are inconsistent with the express provisions of this Act, shall continue to apply to contracts of marine insurance.' (italics supplied)

${ }^{984}$ Halsbury, $\mathrm{n} 982$, vol 19(1), does not refer to any. See also J Gilman et al, Arnould's Law of Marine Insurance and Average $\left(1^{\mathrm{st}} \mathrm{ed}, 1848 ; 17^{\text {th }}\right.$ ed, 2008); Chalmers Marine Insurance Act 1906 ( $1^{\text {st }}$ ed, 1901; 10 $0^{\text {th }}$ ed, 2007); S Hodges, Law of Marine Insurance (1 ${ }^{\text {st }}$ ed, 1996, rep 2005); J Lowry et al, Insurance Law: Doctrine and Principles ( $3^{\text {rd }}$ ed, 2011); J Birds, Birds' Modern Insurance Law ( $1^{\text {st }}$ ed, 1982; $9^{\text {th }}$ ed, 2010); MA Clarke, The Law of Insurance Contracts $\left(1^{\text {st }}\right.$ ed, $1989 ; 5^{\text {th }}$ ed, 2006).

${ }^{985}$ Sale of Goods Act 1893, s 61.

${ }^{986}$ It provides: 'The rules of the common law, including the law merchant, except in so far as they are inconsistent with provisions of this Act, and in particular the rules relating to the law of principal and agent and the effect of fraud, misrepresentation, duress or coercion, mistake, or other invalidating cause, apply to contracts for the sale of goods.'

${ }^{987}$ Halsbury, n 982, vol 9(1), does not refer to any. See also: (a) PS Atiyah, Atiyah's Sale of Goods (1 ${ }^{\text {st }}$ ed, 1957; 12 ${ }^{\text {th }}$ ed, 2010); (b) MG Bridge, The Sale of Goods ( $3^{\text {rd }}$ ed, 2014); (c) Benjamin 's Sale of Goods ( $1^{\text {st }}$ ed, 1868; $9^{\text {th }}$ ed, 2014), see $9^{\text {th }}$ ed, para 1.007. 
previously stated. ${ }^{988}$ So, when did the concept of the law merchant die?

- One would suggest that it is possible to fix on a final date, 1898 - the date when the last piepowder court is alleged to have sat (at Hemel Hempstead);

- However, this was only a formality and, as can be seen from Appendix B, a large amount of early legislation on commercial matters - including on weights and measures as well as the Statutes of Acton Burnell 1283, Statute of Merchants 1285 and Statute of the Staple 1353 - was repealed in 1863. Thus, 1863 is another possible date;

- That said, perhaps - even more appropriately - 1835 may be said to be the terminal date since the Municipal Corporations Act 1835 abolished all remaining restrictions on trading by retail or wholesale. This, effectively, ended the concept of 'merchant' as a distinct category of person or of trade.

The fourth edition of Goode, edited by McKendrick, has proposed an even earlier date:

By the time of his retirement [that of Mansfield CJ in 1788], the law merchant had become fully absorbed into the common law, so that a century later the draftsman of the Bills of Exchange Act 1882 and the Sale of Goods Act 1893 was able to provide in both statutes that 'the rules of common law, including the law merchant' [emphasis added] should continue to apply to bills of exchange and contracts of sale respectively. ${ }^{989}$

As it is, ex abundante cautela, I have settled on 1898. By that date - regardless of differing viewpoints as to whether the law merchant was a distinct area of law or whether it derived from (or was an example of) a ius gentium - one thing seems certain. All that the law merchant comprised (even taking into account the more extensive views of civilian lawyers) no longer existed by 1898. It had either been incorporated into legislation or the common law or it was obsolete (often long so). See Appendix B. In conclusion, by 1898, there were no 'merchants' and there was no 'law merchant.' Thus:

- No 'Merchants.' In early times, 'merchant' covered anyone who bought, and sold, goods as a profession. In 1661, Godolphin excluded from this term isolated acts of sale, artisans (i.e. those who made and sold goods) and usurers (but included bankers). Jacob followed this in his law dictionary of 1729. In his commercial directory of 1752, Beawes also excluded: (a) shopkeepers; and (b) those who attended markets and fairs (market traders). By the final edition of Molloy, in 1769, ware housekeepers were also excluded and, by the end of the $18^{\text {th }}$ century, bankers were being referred to as such and were excluded from the definition of merchant. In his commercial directory in 1803, Montefiore excluded retailers. Thus 'merchant' became, by then, limited to describing a person who - as a profession - sold goods by way of wholesale, especially in the case of export trading. The Municipal Corporations Act 1835 ended restrictions on selling by way of retail or wholesale. Thereafter, the term 'merchant' died away rapidly - both in general and legal speech;

- No Law Merchant. Piepowder courts, local admiralty courts and gilds were becoming defunct by the $16^{\text {th }}$ century. Local admiralty courts were abolished in 1835 (save for the Cinque Ports' Court of Admiralty, obsolete since 1914). The HCA merged with the High Court in 1875 (equity and the common law also being combined) and the last piepowder court sat in 1898.

- The Statutes of Acton Burnell 1283, Statute of Merchants 1285 and Statute of the Staple 1353 were repealed in 1863. Wager of law was abolished in 1833. Letters of marque and reprisal were no longer issued after 1815 and could no longer be issued after 1856. Tallies became obsolete by early Victorian times, with Exchequer tallies ending in 1826;

- By 1802 , maritime law began to be treated as a separate field of law. The Laws of Oleron, laws of Visby, the Consolato del Mar etc. were obsolete by the $18^{\text {th }}$ century. Charterparties, bills of lading and stoppage in transit had never been, legally, restricted to merchants as such;

- Insurance, banking, partnership and factoring had never been legally restricted to merchants as such - although merchants were often involved in them. By Victorian times they had become discrete fields of law.

\footnotetext{
${ }^{988}$ See: (a) JA Slater, Principles of Mercantile Law (1 $1^{\text {st }}$ ed, 1884); (b) TM Stevens, Elements of Mercantile Law (1 ${ }^{\text {st }}$ ed, 1890); (c) J Hurst \& R Cecil, Principles of Commercial Law ( $1^{\text {st }}$ ed, 1891); (e) MM Ullah \& JG Colclough, Manual of Contract $\left(1^{\text {st }}\right.$ ed, 1895).

${ }^{989}$ McKendrick, n 766, p 7. See also KP Berger, The Creeping Codification of the Lex Mercatoria (Kluwer, 1999), p 1 'With the codification wave of the $19^{\text {th }}$ century, [the] ancient law merchant, based on the practices and statutes of powerful trade-guilds, customary law and the case law of the curiae mercatorum, had fallen into oblivion.'
} 
The death of the concept of 'law merchant' was strange, since it happened without any one really noticing. However, it was the same with all London, and local, customs. ${ }^{990}$ By 1898, all London commercial customs, including any in charters, ${ }^{991}$ - as well as (likely) all local customs - had either become obsolete or become part of legislation. Their passing was also not (likely) mourned. As Coke CJ had stated such customs were 'against' the common law. That is, they were particular, being designed to benefit a specific category of person as opposed to the general population. ${ }^{992}$ In a more egalitarian society they were unnecessary.

\section{In conclusion, by 1898, the concept of the 'law merchant' had become redundant.}

\section{ACADEMIC WRITING ON THE LAW MERCHANT}

Although the law merchant, legally, had become extinct by Victorian time, it did not wholly disappear. Instead, from the 1890's, there emerged a volume of academic writing on it. Unfortunately, rather like the writing of Davies and others in the $17^{\text {th }}$ century, there was a marked tendency of these writers to bring pre-conceived notions to the subject matter. Thus, unsurprisingly, the found what they were looking for. Once more there was a resurrection of belief that the English domestic law merchant in early times had derived from a ius gentium. Also, that it had been a distinct field of law, one which the common law, slowly and reluctantly, absorbed. This writing was also a case of 'follow my leader', since most of it relied on MacDonell (whom Scrutton closely followed) or Holdsworth. Of all of it, Holdsworth has the most merit, not least since writers such as Mitchell and Bewes actually dedicated very little space to the position under English law.

\section{(a) MacDonell: Compendium of Mercantile Law}

In 1890, Macdonell, editor of the $10^{\text {th }}$ edition of the Compendium of Mercantile Law, ${ }^{993}$ discussed the origins of mercantile law in his introduction. ${ }^{994} \mathrm{He}$ asserted the following:

- Ius Gentium. The lex mercatoria was once spoken of as a form of private international law and it was the 'fact that the same rules of law were generally applied throughout civilized Europe'. ${ }^{995}$ Also, 'undoubtedly', there was a time when the 'lex mercatoria, though the law of England, was also the law of other nations, and was the law of England because it was the law of other nations'; 996

- $\quad$ Foreign Laws \& Customs. Some parts of mercantile law were 'undoubtedly' borrowed from Roman law ${ }^{997}$ with a 'more important source' being collections of maritime usages and customs (coutumiers) drawn up for the use of merchants and lawyers. ${ }^{998}$ Macdonell referred to: (a) international fairs in the Middle Ages where the dealings of merchants required the use of simple rules; ${ }^{99}$ (b) the staple courts; 1000 (c) gild merchants; ${ }^{1001}$ and (d) mercantile customs; ${ }^{1002}$

\footnotetext{
990 See McBain, n 44. Also, Aske, n 16.

991 The City of London by this time was tiny in the terms of the number of citizens to which they could have applied, see $n$ 473 (c. 31,000 people resident in the City in 1896). Today, it is even smaller (c. 13,000). All these customs only applied to the City of London, not to Greater London.

${ }_{992}$ City of London's Case (1610) 8 Co Rep 127 (77 ER 658) per Coke CJ 'There are divers customs in London which are against common right, and the rule of the common law, and yet they are allowed in our books...because they have not only the force of a custom, but are also supported and fortified by authority of Parliament. 'Day v Savadge (1614) Hob 86 (80 ER 235) per Hobart CJ at p 87 'such customs are of the nature of local laws, peculiar laws for that city, general to all the citizens, differing from the general law of the kingdom.'

${ }_{993}$ MacDonell, $\mathrm{n} 375$. He was a master of the Supreme Court.

${ }^{994}$ At $\mathrm{p}$ lxiii 'In this treatise mercantile law is understood to comprise partnership, the law of joint stock companies, agency, bills of exchange, contracts with carriers, the contract of affreightment, insurance, sale, bottomry and respondentia, debt, guaranty, stoppage in transit, lien and bankruptcy.'

${ }^{995}$ Ibid, p lxiv.

${ }^{996}$ Ibid, lxv.

${ }_{997}^{97}$ McDonell referred to the Roman law of bailment, the chief doctrines of partnership, principal and agent, contract of affreightment, general average, contracts of bottomry and respondentia and salvage.

${ }_{998}$ Ibid, pp lxvi-vii. He referred to the laws of Trani, Oleron, Wisby and the Consolato del Mare.

${ }^{999}$ Ibid, p lxx 'It was necessary that there should be expeditious settlements of disputes, and summary executions to enforce decisions between buyers and sellers, who were strangers to each other, and who dispersed to distant places when their transactions were over. Hence arose the market law...expanded and modified, it became a principal part of the lex mercatoria.'

${ }^{1000} \mathrm{Ibid}$, p lxxiii. MacDonell also referred to the Statute of Acton Burnell 1283 and the Statute of Merchants 1285.

${ }^{1001}$ Ibid, p lxxiv.

${ }^{1002}$ Ibid, p lxxvii-iii. However, MacDonell failed to note that some of the customs that he cited (from Davies, see $\mathrm{n} 18$ ) were London customs. Also, that the custom of foreign attachment (which he mentioned) was a London custom. Cf. W Brandon, A Treatise upon the Customary Law of Foreign Attachment (London, 1861), ch 1. Foreign attachment enabled the attachment of the goods of a foreign (a non-citizen) to be attached for his debts, when the goods were in the hands of a third party. It was a speedy form of attachment.
} 
- English MercantileTexts. Before the end of the $14^{\text {th }}$ century, there were no writers on mercantile law (Mitchell did not cite the text, Lex Mercatoria, see 8). Further, the writings of Malynes, Marius, Molloy and Beawes were little more than translations of Italian and German works. ${ }^{1003}$

MacDonell divided the history of mercantile law into 3 stages:

- When it was administered in special courts (a period up to the appointment of Coke as CJ in 1606); $;^{1004}$

- Later, it chiefly consisted of a body of customs binding only a special class (a period up to the appointment of Mansfield CJ);

- Finally, these customs were incorporated in the general law and they were binding on all, whether merchants or not.

The difficulty with Macdonell's analysis is that it was cursory and that he cited no detailed evidence for any ius gentium; or that the early law merchant was a distinct body of law. Nor did he note that many customs of merchants were - first of all - London customs and that they were shared with others.

\section{(b) Scrutton (1891)}

In 1891, Scrutton (at that time, a lecturer in common law at the Law Society) delivered a series of lectures with the title 'The Elements of Mercantile Law. ${ }^{1005}$ Scrutton noted there were few texts on the law merchant ${ }^{1006}$ and few early cases on commercial law. ${ }^{1007}$ The reason, he surmised, was that such cases were dealt with by special courts and under a special law. Citing Davies, Malynes, Blackstone, Mansfield CJ, and Lord Blackburn, ${ }^{1008}$ he stated (following MacDonell) that there were 3 stages of development in the mercantile law:

- $\quad$ Stage 1 - To 1606. Prior to the appointment of Coke as CJ, the law merchant was administered as ' $a$ special law administered by special courts for a special class of people', ${ }^{1009}$

- Stage 2 - To 1756. From Coke to the appointment of Mansfield as CJ, 'the special courts die out, and the law merchant is administered by the king's courts of common law, but it is administered as a custom and not as law, and at first the custom only applies if the plaintiff or defendant is proved to be a merchant. ${ }^{1010}$ Since the law merchant was a custom, the custom and the facts were left to the jury without any directions in point of law; ${ }^{1011}$

- $\quad$ Stage 3 - From 1756. Mansfield CJ built up 'a system of law as part of the common law, embodying and giving form to the existing customs of merchants'. Mansfield CJ 'with a Scotch training, was not too favourable to the common law of England, and he derived many of the principles of mercantile law that he laid down, from the writings of foreign jurists, as embodying the custom of merchants all over Europe, 1012 as well as employing special juries of merchants.

Scrutton then cited what was, effectively, a fourth stage. There was now (i.e. in 1891) 'a fairly complete code of mercantile rules' and the English courts 'in the wealth of English commercial law' were entitled to 'disregard the law of other countries. ${ }^{1013}$ Further, the law merchant could be extended by usages that had sprung up. ${ }^{1014}$

\footnotetext{
${ }^{1003}$ Ibid, pp lxxx-xxxi 'The works of Malynes, Marius, Molloy and Beawes....are adaptations, in parts little more than translations, of the writings of Italian and German writers'.

${ }^{1004} \mathrm{Ibid}$, p lxxxii 'administered in special courts, and for the purpose of settling the disputes of a special class, subject to peculiar duties and possessed of peculiar rights.'

${ }^{1005}$ See $\mathrm{n} 25$.

${ }^{1006}$ Scrutton, $\mathrm{n} 25, \mathrm{p} 1$ thought that the 'best, and almost the only satisfactory sketch of the history of the law merchant' was that of Macdonell (see (a)). He also cited the Prefaces to MD Chalmers, Bills of Exchange, see $\mathrm{n} 980$ and Lowndes, see n 361. See also Scrutton, n 188, chs 13 \& 14.

${ }^{1007} \mathrm{Ibid}, \mathrm{p} 4$ 'it is a curious fact that one finds in the reports of that century, two hundred years ago, hardly any commercial cases. If one looks up the law of bills of exchange, 'the cases on the subject are comparatively few and unimportant till the time of Lord Mansfield.' He cited the Preface to Chalmers (see $\mathrm{n} 980$ ) and Park, see $\mathrm{n} 861$.

${ }^{1008}$ M'Lean v Clydesdale Banking Co (1883) (Privy Council) 9 App Cas at p 105 'the general law merchant for many years has in all countries caused bills of exchange to be negotiable... There are in some cases differences and peculiarities which by the municipal law of each country are grafted upon... but the general rules of the law merchant are the same in all countries.'

${ }^{1009}$ Scrutton referred to fairs and courts of piepowder as well as to local maritime courts.

${ }^{1010}$ Scrutton, n 25, p 13.

${ }^{1011}$ Ibid, pp 13-4 'as a result little was done towards building up any system of mercantile law in England.'

1012 Ibid, p 15.

${ }^{1013}$ Scrutton, n 25, p 17 cited Svendsen $v$ Wallace (1884) 13 QBD 69 at pp 72-3, per Brett MR 'It was urged that even if the proposition is stated in terms larger than have hitherto been recognised in English law, yet it ought now to be adopted in order to bring the principle of English law
} 
Scrutton noted 6 pre-requisites for a custom to be established ${ }^{1015}$ but that - for a mercantile custom - only 4 were now required. ${ }^{1016}$ In the remainder of his lectures, Scrutton considered negotiable instruments, shipping documents, the Factors' Acts, insurance policies and contracts of sale. ${ }^{1017}$ In particular, he considered that 'Many of the rules of mercantile law, the law merchant, are directed to evade inconvenient rules of the common law', citing 'market overt' as an example ${ }^{1018}$ (however, market overt, likely, originated long before the law merchant and it did not apply just to merchants, but to anyone buying in a market). ${ }^{1019}$ In the case of BOE, Scrutton noted that the Bills of Exchange Act 1882 now, legislatively, provided for such matters. ${ }^{1020}$

In conclusion, Scrutton's analysis - including the stages of development of the law merchant - was based on Macdonell.

\section{(c) Holdsworth (1901)}

Holdsworth, in the first volume of his History of English Law completed in 1901, stated:

The law merchant of primitive times comprised both the maritime and the commercial law of modern codes. From the earliest period in their history an intimate relationship has subsisted between them. Both applied peculiarly to the merchants who, whether alien or subject, formed in the Middle Ages a class very distinct from the rest of the community. Both laws grew up in a similar manner from the customary observances of a distinct class. Both laws were administered in either the same or in similar courts, ${ }^{1021}$ which were distinct from the ordinary courts. Both laws differed from the common law. ${ }^{1022}$ Both had in the Middle Ages an international character; and both continued to possess this international character right down to modern times. ${ }^{1023}$ (italics supplied)

This thesis Holdsworth pursued both throughout the rest of the volumes of his work and generally. Doubtless, Holdsworth's view was influential in his time and his views reflected the prevailing tide. However, in hindsight, his analysis was an over-simplification of the position and it ignored the statements of the differences between the common law and the law merchant both in the Lex Mercatoria (see 8) and in Davies (see 19(a)). Further:

- Not all commercial law in medieval times was the law of merchants. For example, the laws on weights and measures, and the Assizes, applied generally and chartered privileges (such as in the London and other town charters) applied to citizens and not just to merchants. Also, people could still trade if they did not belong to a guild and, to belong to a gild, one did not have to be a merchant. Further, maritime law applied to mariners as well as merchants (the reason why merchants were closely associated with it, initially, is that most mariners would also have been transporting goods by sea, to sell);

\footnotetext{
on the subject into consonance with the laws of all other countries. But to this I cannot agree. It is useless to inquire whether the law is, as stated, the same in all European countries. For if it is, yet no English court has any mission to adapt the law of England to the laws of other countries; it has authority only to declare what the law of England is.'

${ }^{1014}$ Ibid, pp 17-8. Scrutton cited Cockburn CJ in Goodwin v Robarts (1875), see n 975.

1015 (a) must date from, at least, 1189; (b) must be continuous from that date; (c) must be universally acquiesced in; (d) must be reasonable; (e) must be certain; (f) must be binding.

1016 (a) and (b) were not required. At p 20 'it is sufficient for you to prove that the custom is certain, so that people know what it is; that it is reasonable, that it is fairly universal...that it has existed for some time (five years may suffice), and that merchants in the trade consider it binding...'

${ }^{1017}$ Much of this has been superceded by legislation or caselaw or is obsolete (for example, bought and sold notes, see Scrutton, n 25, pp 178-85).

${ }^{1018}$ Scrutton, n 25, pp $22 \& 24$

1019 See n 255. See also Bentley v Vilmont (1887) 12 App C at p 471

${ }^{1020}$ Scrutton, n 25, p 35 'on all matter treated on by that Act [Bills of Exchange Act 1882] the law merchant is now to be found in its clauses, and not in the cases and customs on which those clauses were founded.' The position on bills of lading was similar as a result of the Bills of Lading Act 1855 (rep 1992). Ibid, p 27.

${ }^{1021}$ Ibid, vol 5, p 144 'In the Middle Ages, when the commercial customary law was administered in special courts for a very separate body of persons, it was something quite outside the common law.'

${ }^{1022}$ See also Holdsworth, n 26, vol 1, p 543 'these courts - maritime and commercial - administered, and, by administering, helped to create the law merchant. It was a law which necessarily differed at many points from the ordinary law...For the most part it was law laid down by the merchants in their courts; and, though particular rules may have differed slightly in different places, its character was essentially cosmopolitan. Of the contents of this customary law the common law courts as yet knew very little. It was admitted to be a law quite distinct from the common law.' See also Ibid, vol 5, p 60 et seq.

${ }^{1023}$ Holdsworth, n 26, vol 1, p 526. Holdsworth, p 528 also stated 'It is probable that in Europe, in the troubled times of the ninth and tenth centuries, the merchants had always known a special market law.' However, there is no evidence of this so early, or of a unified practice.
} 
- There is a contradiction between Holdsworth - on the one hand - indicating that the law merchant differed from the common law (he cited one example) ${ }^{1024}$ and - on the other - citing the Lex Mercatoria (c. 1280) and noting that the writer regarded the law merchant as a 'mere off-shoot of the common law, and he can only point to three specific differences.; ${ }^{1025}$

- In respect of maritime law, Holdsworth thought the laws of Oleron were 'transplanted' to England, something of an equivocation ${ }^{1026}$ though it seems likely he accepted they had become part of English law anyway. As to other maritime laws - such the Rhodian law, laws of Visby, Consolato del Mare etc. - Holdsworth failed to note the differences between them - as well as the paucity of times they were actually employed in English caselaw as persuasive authority. ${ }^{1027}$

In short, although Holdsworth was the primary modern exponent of the law merchant: (a) being part of a ius gentium; (b) being distinct to the common law in early times; (c) being incorporated into the common law; he was short on detail. ${ }^{1028}$ In particular, he failed to analyse the precise ways this an asserted extensive - and international - law merchant differed from the common law. Also, since the courts in which it was employed (piepowder and local admiralty courts) were obsolete by the end of the $16^{\text {th }}$ century (on Holdsworth's own admittance) ${ }^{1029}$ what then of the concept?

- Holdsworth accepted that the law merchant (or such as was left of it by then) was assimilated into the common law - he termed what was left as rules of 'commercial' law as opposed to rules of a 'law merchant'; ${ }^{1030}$

- Even accepting the thesis of Holdsworth that there was a distinct law merchant, it was a short-lived phenomenon. In c. 1280 it only comprised 3 differences and by the end of the $16^{\text {th }}$ century (according to Holdsworth) it was all gone.

In conclusion, Holdsworth provided no evidence of the law merchant being a ius gentium or, that it was - in early times - a separate branch of law to the common law.

\section{(d) Mitchell (1904)}

In 1904, Mitchell wrote his Essay on the Early History of the Law Merchant. He noted:

The law merchant has been aptly called 'the private international law of the Middle Ages'. It was regarded as a kind of ius gentium known to all the merchants throughout Christendom and the later writers who treated the subject laid stress upon its international character. ${ }^{1031}$

Initially, Mitchell challenged this assumption:

\footnotetext{
${ }^{1024}$ Ibid, p 543 'One illustration of the ignorance of the common law courts of the commercial usages of the period, and of the rules of law which governed those usages, will sufficiently explain why the courts and law of the merchants were at this period wholly distinct from the common law courts and the common law'. Holdsworth referred to the records of the fair courts, which indicated that a writing obligatory payable to bearer was known among merchants as early as the $13^{\text {th }}$ century. However, he made no reference to London customs.

${ }^{1025}$ Ibid, p 539. Holdsworth also cited Coke's words that the law merchant was part of the common law (see n 805). Ibid, vol 5, p 145.

${ }^{1026}$ Ibid, p 527. See also vol 5, p 120. Ibid, p 129 'England based its maritime law upon the laws of Oleron.' Ibid, p 123, Holdsworth noted that the original 24 laws of Oleron were supplemented by 11 more in the $13^{\text {th }}$ century. He also accepted, Ibid, $\mathrm{p} 123$ ' There were many problems for which they [the laws of Oleron] made no provision, and there were many points upon which their meaning was by no means clear. Moreover, in course of time it was certain that peculiarities of national maritime custom would begin to make their influence felt.' As to these 11 additional articles, Holdsworth stated, Ibid, p 124 'That they were accepted in England is clear from the fact that they are included in the Black Books and in other English MSS of these laws.' He thought that the Black Book was probably compiled in the reign of Henry VI (perhaps 1422-5). Ibid, $p$ 125. Cf. Twiss, $\mathrm{n} 23$, vol 3, p xii who thought that 10 of the 11 additional articles 'were received in England as part of the Laws of Oleron in the reign of Edward III [1327-77].' The $11^{\text {th }}$ article was likely from the rime of king John (1199-1216), see $\mathrm{p}$ xi.

${ }^{1027}$ By Victorian times, Holdsworth accepted they were irrelevant anyway.

${ }^{1028}$ Holdsworth, n 26, vol 1, p 569 stated 'The common law had borrowed certain rules from the law merchant. The rules that there is no warranty of title in a sale of goods, and that, under some circumstances, a sale in market overt by a non-owner will pass the property, probably come from this source. The merchant's view of the efficacy of the earnest money to bind the bargain was recognised by the Statute of Frauds [1677, s 17, see n 249]. However, one would assert that market overt was a London custom and that it did not apply to merchants, but generally. See ns 74, 255 and 1019.

${ }^{1029}$ Holdsworth, n 26, vol 1, p 569 'the fairs and their courts were decadent by the end of the sixteenth century....By the end of the sixteenth century the internal trade of the country was regulated by a common law thus modified and not by a separate law merchant.' See also vol 5 , $p$ 112 'English fairs began to decline in the fifteenth and sixteenth centuries.'

${ }^{1030} \mathrm{Ibid}, \mathrm{n} 26$, vol 5, p 148 'It is clear however that, as early as the first half of the seventeenth century, the process of incorporating the rules of commercial law into the common law had begun'. This reference to the 'first half of the seventeenth century' contradicts his statement that by the end of the sixteenth century, there was no longer a law merchant, see n 1029.

${ }^{1031}$ Mitchell cited Malynes and Davies, see 19.
} 
Strictly construed it was not correct for the law as it existed in the $17^{\text {th }}$ century, and it was still less correct for the law merchant in the earlier stages of its evolution. There was during the early Middle Ages no strictly uniform system of mercantile law administered throughout the whole of Europe either in town or seaport or fair. ${ }^{1032}$ (italics supplied)

That said, and although the law merchant was vague and indefinite, Mitchell asserted that: ${ }^{1033}$

in spite of its vagueness the law merchant existed. In every commercial country in Europe there were rules and legal doctrines for merchants and mercantile transactions that were regarded alike by merchants and by jurists as distinct from the common law of the land. These rules and doctrines, which were distinct...from the common law, were the law merchant. Each country, it may almost be said each town, had its own variety of the law merchant, yet all were but varieties of the same species. Everywhere the leading principles and the most important rules were the same, or tended to become the same. ${ }^{1034}$

Mitchell's Essay had as its object 'to trace the development of the common essential elements that are found in the early law merchant of every country. ${ }^{1035}$ In particular, he noted that:

- custom was the 'ruling principle and the originating force of the law merchant' 1036 and the summary nature of its jurisdiction as well as the spirit of equity. He also accepted that, in this, England lagged behind since the records of the St Ives court 'show that formalism and technicalities still held their ground.'; 1037

- the 'most strking feature of the law merchant' was 'its strongly marked international character' 1038 which entitled the law merchant to be called the 'private international law of the Middle Ages. ${ }^{1039}$

For the rest of his Essay, Mitchell mainly concentrated on fairs and fair courts. ${ }^{1040} \mathrm{He}$ also concentrated on the laws of Italy, France and Germany (and, to a lesser extent, Spain), but with little reference to English law.

- The problem with his Essay is his view of the Continental position (whether correct or not) he simply transposed on English law; he never analysed Anglo-Saxon law or the writings of Bracton or Britton or Fleta. Further, although quoting the treatise Lex Mercatoria, Mitchell asserted that the law merchant was separate from the common law when the author of that treatise held the opposite view;

- There was also much contradiction in what Mitchell wrote. Thus, Roman law was 'in the main, the basis of the law merchant'. Yet, 'customs and usages of the merchant himself remained the decisive factor in the development of the law merchant. ${ }^{1041}$ Further, while adhering to the view of a ius gentium, Mitchell accepted there was no uniform system of mercantile law.

Thus, it seems clear that Mitchell was of the view that: (a) the law merchant derived from Roman law but was developed in the medieval ages from custom; (b) it was distinct from English law; and (c) it was part of a ius gentium. This reflected much of the views of Macdonnell and Scrutton. However, the Essay contained little

\footnotetext{
${ }^{1032}$ Mitchell, n 30, pp 1-2. Also, p 5 'Maritime law... which showed great uniformity in later times, was far from uniform during the middle ages. Numerous local laws and customs existed which were gradually supplanted in the north by the laws of Oleron and Wisby, and in the south by the laws of Barcelona. It was a slow process, however, for as late as the $17^{\text {th }}$ century the code of Amalfi was recognised in southern Italy, while legislation in England, Holland and France soon began to create fresh divergences.'

${ }^{1033} \mathrm{Ibid}, \mathrm{p} 8$ 'The law merchant, in fact, was vague and indefinite; in many of its courts the law was regarded as a purely customary law to be declared, in case of doubt, by the merchants of the courts themselves...'

${ }^{1034}$ Ibid, p 9. Ibid, p 7 'in spite of minor differences, the international character of the law merchant as administered in the fair courts cannot be denied.'

${ }^{1035}$ Ibid, p 10. At $\mathrm{p} 10$ 'The law merchant... was a body of rules and principles relating to merchants and mercantile transactions, distinct from the ordinary law of the land.' Ibid, p 38 'It was in fair and market and town that the law merchant was created and developed...'.

${ }^{1036}$ Ibid, p 12.

${ }^{1037}$ At p 17. Ibid, pp 12-6.

${ }^{1038}$ At $\mathrm{p} 20$.

${ }^{1039}$ At $\mathrm{p} 21$. See also $\mathrm{p} 156$ 'The whole history of the law merchant in Europe during the Middle Ages was characterised by a constant advance towards uniformity and by the successful assertion of new principles of law.'

${ }^{1040}$ At p 27 'It does not seem too much to say that out of the immunity of market and fair courts rose the law merchant.' Ibid, p 38 'It was in fair and market and town that the law merchant was created and developed, and it is in the records of fair and market, of town and seaport, that the sources of its history mainly lie.' Ibid, p 39 'In the $10^{\text {th }}$ and $11^{\text {th }}$ centuries, when the law merchant was in process of formation, the only courts that could in any sense be regarded as special courts for commercial purposes were held in markets and fairs.'

${ }^{1041}$ At, pp 160-1. Ibid, p 161 'When the true interests of commerce were at stake the merchant persistently and obstinately refused to recognise the rules of Roman law....'Out of his own needs and his own views' the merchant of the Middle Ages created the law merchant.'
} 
analysis on English law as such. ${ }^{1042}$ Thus, one would assert that, at most, Mitchell proved that there was some degree of commonality between English and Continental law in that they all had laws on fairs, maritime matters, BOE's etc. What he failed to prove was a ius gentium.

In conclusion, Mitchell provided much detail on Continental law (Italian law especially) but did not show how, in the relatively little he wrote on English law, it was distinct from the common law or that it was part of a unified ius gentium.

\section{(e) Thornely (1904)}

Thornely (a barrister) wrote a brief History of the Law Merchant and Negotiability. His view of the law merchant was enunciated in the opening lines:

Although the actual origin of the law merchant is enveloped in obscurity, this much may be said with certainty, it existed in its early stages as a body of varying customs obtaining among a certain class of the population - the class of merchants. As the number of the merchants increased, so the existence of these customs became more pronounced, with the result that they gradually became of sufficient importance to be generally recognized by the king's court, and finally to be included in the general law of the land. ${ }^{1043}$

Thornely considered that a notable peculiarity of the law merchant in its earlier stages was its international character. ${ }^{1044}$ He referred to a body of rules governing merchants distinct from the common law:

These rules formed a code of law to be applied rather to a particular class of mercantile transactions, than to a class of men, in that they consisted chiefly of a group of rules of evidence, such as the proof to be given of sales and contracts, the value of the tally, and the nature of earnest money. They were rules which were regarded as being specially known to merchants, and which were then declared by them in the courts holden at fairs and markets: they were rules which were not looked upon as purely English but as a ius gentium known and acknowledged by all the merchants of the then known world. ${ }^{1045}$ (italics supplied)

Thornely considered the law on fairs, the staple, maritime law and BOE to be part of this ius gentium. ${ }^{1046}$ The problem with this analysis is that (even less than Mitchell) he failed to provide evidence that the law merchant was distinct from the common - as opposed to being business practices accepted by the courts and, thereby, becoming part of the common law. Nor did he provide evidence that the courts at fairs in England - or that the laws of Oleron, Visby, the Consolato del Mare etc. (which were quite distinct) - comprised a ius gentium universally applied in England and by all merchants of the 'then known world.'

In conclusion, Thornley provided no substantive evidence of the English law merchant being part of a ius gentium or a distinct branch of law.

\section{(f) Bewes (1923)}

Bewes, a barrister, produced - in 1923 - his Romance of the Law Merchant. ${ }^{1047}$ The title was rather infelicitous, intimating a fairy tale element to the history of the law merchant, and, indeed, when describing the early history there was much conjecture and much wandering through history. ${ }^{1048}$ However, it seems clear that Bewes wanted to correct a notion that the law merchant had been 'invented' by Italians. Thus, his opening words were:

It has been confidently assumed by most writers that the law merchants arose in Italy in the central part of the Middle Ages, was chiefly founded on Roman law, and was carried by the traders of that country, who at that time almost monopolized international trade, into every country which they penetrated. ${ }^{1049}$

Bewes went on to show (doubtless, correctly) that trading - and various mechanics of the same - existed long

\footnotetext{
${ }^{1042}$ Mitchell did not analyse London customs. Nor how the customs of merchants at fairs and seaports were also available, to a great extent, to non-merchants.

1043 Thornely, n 32, p 1 .

${ }^{1044}$ Ibid. He was sceptical whether it could be traced back to Roman law, however. Ibid, p 6

1045 Ibid, p 6. Ibid, p 8 'jus gentium, that is, as being of universal application among one class of the population of the civilised world.'

${ }^{1046}$ As to the Laws of Oleron, while avoiding judgment on whether they had been enacted by Richard I, at $\mathrm{p} 8$, 'it is certain that the judgments of Oleron had universal application.' (italics supplied).

${ }^{1047}$ See n 34. The sub-title was 'An Introduction to the Study of International and Commercial Law with some account of the Commerce and Fairs of the Middle Ages.'

1048 The text cannot, unfairly, be described as a work of legal comparative history as opposed to an analysis of the English law merchant.

1049 Bewes, n 34, p 1.
} 
before the Italians. Bewes referred to Macdonell and was disinclined to see Roman law as the source of the law merchant. Rather, it was the 'usages of the fairs as the true and transcendental spring from which flowed the present law of merchants.' ${ }^{1050}$ As to what it comprised:

There is some initial obscurity as to what in truth constituted or now constitutes the substance of the lex mercatoria, but it may be best defined as the law administered as between merchants in the consular or commercial courts, some of it being substantive law and some rules of evidence and procedure... ${ }^{1051}$

Bewes thought that the 'two great distinctive elements' were 'good faith and dispatch. ${ }^{1052}$ He also referred to 15 other 'chief distinctive points to be noticed in the law of the merchants' ${ }^{1053}$ However, most of his analysis - and citations - were to Continental law, as was much of his work which concluded with a long citation from a text of the French writer, Huvelin, on fairs. ${ }^{1054}$ Apart from these matters, Bewes did not say much on how he viewed the English law merchant. As it is, his work did not analyse early English law on the matter (whether Anglo-Saxon law or Bracton etc.) and he did not consider whether the concept of 'law merchant' may have changed over time.

In conclusion, Bewes discounted the thesis that the law merchant was founded on Roman law and his work was a comparative text which did not concentrate on the specifics of English law.

\section{(g) Conclusion}

The texts of Mitchell and Bewes are works of comparative law with little attention to the English law merchant. Thornely dealt mainly with the negotiability of BOE and Scrutton followed MacDonell. The most detailed analysis was that of Holdsworth. However, his idea of a distinct early medieval law which merged into the common law - as well as the English law merchant being part of a ius gentium - is not sustainable.

\section{THE LAW MERCHANT IN MODERN TIMES}

\section{(a) Texts on Commercial Law: 1898-1955}

There were a number of legal texts on commercial (mercantile) law from 1898-1984 ${ }^{1055}$ as well as on contract. ${ }^{1056}$ These evidence a great decline in mention of the law merchant. The principal texts on commercial law in this period were:

- Ranking, Mercantile Law (1911-1975); ${ }^{1057}$

- Slater, Mercantile Law (1884-1977); ${ }^{1058}$

- Stevens, Elements of Mercantile Law (1890-1978); $;^{1059}$

\footnotetext{
${ }^{1050}$ Ibid, p 13.

${ }^{1051}$ Ibid, p 14.

1052 Ibid, p 19.

1053 Ibid, pp 19-25.

${ }^{1054}$ P Huvelin, Essai Historique sur le Droit des Marches et des Foires (Paris, 1897).
}

1055 See: (a) WD Edwards, Commercial Law (1 $1^{\text {st }}$ ed, 1900); (b) A Nixon \& RW Holland, Commercial Law (1 $1^{\text {st }}$ ed, 1907); (c) TL Davies, Banking and Commercial Law ( $1^{\text {st }}$ ed, 1920); (d) TS Kerr, Commercial Law ( $1^{\text {st }}$ ed, 1939); (e) FJ Wright, Commercial Law (1 ${ }^{\text {st }}$ ed, 1948-50); (f) MR Emanuel, Lectures on Mercantile Law (1 $1^{\text {st }}$ ed, 1933).

1056 See: (a) MR Emanuel, Contracts (2nd ed, 1906); (b) AT Carter, Elements of the Law of Contract (1st ed, 1902); (c) WGH Cook \& JW Baggally, Elements of the Law of Contract ( $\left.1^{\text {st }} \mathrm{ed}, 1931\right)$; (d) Carter, Elements of Contract ( $\left.1^{\text {st }} \mathrm{ed}, 1902\right)$; (e) GC Cheshire \& CHS Fifoot, Law of Contract ( $1^{\text {st }}$ ed, 1945); (f) AB Keith, Elements of the Law of Contracts $\left(1^{\text {st }} \mathrm{ed}, 1931\right)$.

${ }^{1057}$ DF Ranking et al, Mercantile Law ( $1^{\text {st }}$ ed $1911,14^{\text {th }}$ ed, 1975). The $13^{\text {th }}$ edition [date], p xxxix-xl stated 'The law merchant, or lex mercatoria...evolved from the general custom of merchants, and is one of the few branches of English law to have been influenced by continental legal methods.' It then stated the orthodox view (see $n$ 836) that the law merchant had existed in special courts at fairs, in markets and in maritime courts. Also, that such customs were recognized, over time, by the common law courts. It concluded 'As the common law courts became stronger and more effective they gradually absorbed the work of the mercantile courts, a process which was completed in the $17^{\text {th }}$ and $18^{\text {th }}$ centuries under the influence if Lord Holt and Lord Mansfield.'

${ }^{1058}$ See $\mathrm{n}$ 988. Lord Chorley, Slater's Mercantile Law (17 ${ }^{\text {th }}$ ed, 1977), $\mathrm{p}$ xlix 'The principal sources of mercantile law are the common law of England, as modified and supplemented by equity, and statute law. To these must be added the law merchant, largely usages of trade and mostly of foreign origin, having been introduced by foreign merchants. During the seventeenth and eighteenth centuries the law merchant was incorporated into the common law, a process for which we have to thank three eminent Lords Chief Justices: Sir Edward Coke, Lord Holt and Lord Mansfield.'

${ }^{1059}$ See n 281. Also, JK Macleod (ed), Stevens \& Borrie's Elements of Mercantile Law (Butterworths, 17 $7^{\text {th }}$ ed, 1978) 'The law governing commerce in this country traces its origins to the law merchant of medieval and early modern times, which was administered in the courts of fairs and markets and the court of admiralty but was ultimately received into the common law by great eighteenth-century judges such as Holt CJ and Lord Mansfield.' 
- Chance, Principles of Mercantile Law (1922-80); ${ }^{1060}$

- Charlesworth, Principles of Mercantile Law (1929-84). ${ }^{1061}$

In all these texts - and lesser texts - reference to the law merchant, or discussion of it, were scant. As to caselaw, Baker, in his article on 'Law Merchant' as a Source of English Law' (2000) stated:

The 'law merchant' is said to be a part of the law of England, and this proposition is acknowledged in our statute law, ${ }^{1062}$ though few if any modern commentators have thought its meaning worth exploration. Moreover, although less is heard of the law merchant nowadays than in the nineteenth century, the expression has occasionally surfaced in recent cases...Most of these recent references, when not simply quoting from nineteenth century judgments, ${ }^{1063}$ are effectively historical statements purporting to explain the source of some rule of common or statute law. In other passages, the term is used rather loosely as a synonym for mercantile or commercial law. ${ }^{1064}$

With regard to the cases referred to by Baker, they all referred to the 'law merchant' as a synonym for commercial law, and not to the older concept of a law which applied to merchants only. Thus:

- Sanders Bros v MacLean \& Co (1883). In the context of a bill of lading, Bowen LJ stated: 'But the practice of merchants...is not based on the supposition of possible frauds. The object of mercantile usages is to prevent the risk of insolvency, not of fraud; and any one who attempts to follow and understand the law merchant will soon find himself lost if he begins by assuming that merchants conduct their business on the basis of attempting to insure themselves against fraudulent dealing. The contrary is the case. Credit, not distrust, is the basis of commercial dealings; mercantile genius consists principally in knowing whom to trust and with whom to deal, and commercial intercourse and communication is no more based on the supposition of fraud than it is on the supposition of forgery.'; ${ }^{1065}$

- Monarch Steamship Co Ltd v Karlshamns Olje-Fabricker (1949). Lord Wright stated: 'It is certainly desirable that as far as possible there should be uniformity between the law merchant as administered in the United States and in Britain.'; ${ }^{1066}$

- $\quad$ The Heron II (1966). Salmon LJ stated: 'It is...of great importance that the law merchant should, so far as possible, be uniform in all the great trading nations of the world, not least in England and the United States of America. '; ${ }^{1067}$

- Miliangos $v$ George Frank (Textiles) Ltd (1976). Lord Simon (dissenting) stated: 'It is quite unnecessary to have recourse to the medieval law merchant - though that is available if required.' 1068 However, it seems clear that Lord Simon - in the context of the case (whether a court could order judgment to be paid in a foreign currency) - was referring to the older commercial law in general (on debt) and not to the law applying only to merchants; ${ }^{1069}$

- Barclays Bank v Quinecare Ltd (1992). Steyn J stated: 'the relationship between merchants is very different from the relationship between a banker and a customer. ${ }^{1070}$

Baker questioned whether the law merchant was worth retaining as a concept. His conclusion was:

\footnotetext{
${ }^{1060}$ EW Chance, Principles of Mercantile Law ( $1^{\text {st }}$ ed $1922,13^{\text {th }}$ ed, 1980).

1061 J Charlesworth, Principles of Mercantile Law $\left(1^{\text {st }}\right.$ ed 1929, $14^{\text {th }}$ ed, 1984). The $14^{\text {th }}$ edition made no reference to the law merchant; nor did P Dobson, Charlesworth's Business Law $\left(16^{\text {th }}\right.$ ed, 1997).

1062 Baker referred to the Bills of Exchange Act 1882, the Sale of Goods Act 1979 and the Marine Insurance Act 1906.

${ }^{1063}$ Baker noted, p 1263, that the most often quoted dictum was that of Bowen LJ in Sanders v MacLean (1883) (see text).

1064 Baker II, n 38, p 1263. He referred to Monarch Steamship (1949) and The Heron II (1966) (see text). Also, to The Maratha Envoy (1977) 1977] QB 324 per Denning MR at $\mathrm{p} 340$ 'The merchants and shipping men on both sides of the Atlantic use the same standard forms of contract, and the same words and phrases. These should be interpreted the same way in whichever place they come up for decision.'

1065 (1883) 11 QBD 327, 343. This was quoted in National Westminster Bank Ltd v Barclays Bank Int Ltd [1975] QB 654 per Kerr J at pp 674-5. Also, in Phoenix General Insurance Co of Greece SA v Halvanon Insurance Co Ltd [1988] QB 216 per Hobhouse J, at p 236. See also Baker II, n 38, p 1263, fn 3 .

1066 [1949] AC 196 at $\mathrm{p} 231$.

1067 [1966] 2 QB 695 at $\mathrm{p} 745$.

${ }^{1068}$ [1976] AC 443 at $\mathrm{p} 484$.

${ }^{1069}$ See argument of counsel at $\mathrm{p} 451$ (action of debt).

${ }^{1070}$ [1992] 4 AE 363 at 377. This was quoted in Macmillan Inc v Bishopsgate Investment Trust plc [1995] 1 WLR 978 per Millett J at 1015.
} 
Neither the remains of the old law merchant, if there are any, nor the new law merchant, if such a thing exists at all, ${ }^{1071}$ can be regarded as an autonomous body of coherent jurisprudence...casual use of the phrase 'the law merchant' or 'lex mercatoria' to describe fluctuating uses - or applied common sense may do more harm than good, especially if it is intended to imply some kind of continuity with a quasi-mythical medieval system of lex mercatoria. ${ }^{1072}$

\section{(b) $\underline{1982-2016}$}

In 1982, there was the first edition of Goode, Commercial Law. In the fourth edition of this work in 2010, edited by McKendrick, ${ }^{1073}$ after referring to the traditional view of the law merchant being distinct and part of a ius gentium $^{1074}$ it stated:

modern scholars have tended to reject the traditional, rather romanticized view of the medieval English law merchant as a separate corpus of law and to regard it instead as 'the factual matrix within which certain types of contract are made, ${ }^{1075}$ and its rules as largely procedural in character, offering speedy justice and the relaxation of technical requirements of pleading and evidence...

One would agree with the tenor of this. In particular, that the law merchant was part of the common law, comprising a speedier process and the relaxation of a few rules of evidence and legal process, in order to facilitate trade. Other modern texts on commercial law, make no reference to the law merchant or very brief reference. ${ }^{1077}$

\section{THE CASE FOR ABOLITION}

When writing about the likely abolition of the custom of market over, which was effected by the Sale of Goods (Amendment) Act 1994, Reynolds stated:

Lovers of curiosities in the law may sigh with regret at the passing into legal history of a rule of medieval origin, as may those who wish to facilitate the sale of stolen goods. All others should welcome this long overdue event. ${ }^{1078}$ (italics supplied)

Certainly, reviewing the law on the market overt in the hundred years from the Sale of Goods Act 1893 until the Sale of Goods (Amendment) Act 1994, it would, actually, have been a good idea to have abolished it in 1893, if not before. It was an anomaly. ${ }^{1079}$ Confusing, of no real benefit and long past its 'sell-by date. ${ }^{1080}$ One would assert that the case for the abolition of the concept of the law merchant is similarly compelling - if not overwhelming. There are no 'merchants' left. And there is no 'law merchant' - that is, privileges applying solely to merchants - left. Thus, by 1898 (nearly 120 years ago) the law merchant had become one and the same as the 'commercial law', that is, that part of the common law that relates to trade and commerce. To retain such a concept simply confuses everyone, without providing any concomitant benefit. As to abolition - as indicated at the beginning of this article - this will not affect the law, one wit, for the following reasons:

\footnotetext{
${ }^{1071}$ I deal with this in 27.

1072 Baker II, n 38, pp 1282-4. Baker noted that his article did not deal with admiralty law nor whether 'some kind of stateless law merchant can be recognized as an autonomous regime for the purposes of international arbitration.'

1073 McKendrick, n 766.

${ }^{1074}$ Ibid, p $3^{\text {‘ }}$ [the] medieval law merchant, which for hundreds of years substituted as a distinct source of rights, administered by courts in which the merchants themselves were judges, before ultimately becoming redundant because of the adaptation of the common law itself to continental needs and usages. The maritime courts, the courts of the fairs and boroughs, and the staple courts, in company with other commercial courts of the Middle Ages, determined disputes involving foreigners not by English domestic law but according to the 'general law of nations' based on mercantile codes and customs such as the Laws of Oleron and reflecting international maritime and commercial practice.' In a footnote, fn 3, it also stated: 'Oleron... was for some while in the ownership of the English Crown as a commune of the province of Guienne (Aquitaine). The decisions of the mercantile community were treated as of the highest authority in England, and the Rolls of Oleron were promulgated by Richard I [1189-99].' Cf. $1^{\text {st }}$ ed (1982), p 31.

${ }^{1075}$ McKendrick cited Baker II, n 38, p 96.

${ }^{1076}$ McKendrick, n 766, pp 6-7.

1077 See e.g. (a) P Dobson, Commercial Law ( $8^{\text {th }}$ ed, 2012); (b) R Bradgate \& F White, Commercial Law (2012) (see also 2000 ed, paras 1.2 , 31.4 and 1.4.6.); (c) LS Sealy \& RJA Hooley, Commercial Law, Text, Cases and Materials (2009); (d) A Brown, Commercial Law (2001); (e) D Keenan, Law for Business ( $1^{\text {st }}$ ed, 1965; $13^{\text {th }}$ ed, 2006);(f) E MacIntyre, Business Law ( $1^{\text {st }}$ ed, 2001; $7^{\text {th }}$ ed, 2006); (g) K Abbott et al, Business Law $\left(9^{\text {th }}\right.$ ed, 2013).

${ }^{1078}$ FMB Reynolds, Abolition of Market Overt (1995) 111 LQR 76, at p 76.

1079 When first accepted, shops did not exist. There were just open markets, in which bystanders and others could witness what was going on. By Elizabethan times (if not before) shops were closed affairs, in which persons entered a private room or building. Thus, the basic element of public view had gone.

${ }^{1080}$ The confusion and legal complexity can be seen in Clayton v Le Roy [1911] 2 KB, pp 1038-45.
} 
- Bills of Exchange Act 1882, Sale of Goods Act 1979 \& Marine Insurance Act 1906. The references to the 'law merchant' in these Acts are to it being part of the common law. Their exclusion would not prevent the courts receiving into the common law any new customs in these areas - albeit, such a prospect is rather remote these days (see below);

- New Lex Mercatoria. From the 1960's, various academics argued for the existence of an international, transnational or global law merchant - a modern lex mercatoria. ${ }^{1081}$ In England, one of these was Clive Schmitthoff, writing in 1961. ${ }^{1082}$ As part of this debate it was asserted this new lex mercatoria was the modern incarnation of a medieval law merchant. There was then extensive academic debate as whether the latter existed. ${ }^{1083}$ In more recent times, the idea of a medieval law merchant has died away somewhat, analysis being concentrated more on the actual development of international or transnational law. In England, articles by Baker (from 1975) and others ${ }^{1084}$ have challenged (one would argue, convincingly) the existence of the English law merchant, in early times, being part of a ius gentium or being a distinct field of law. As it is - leaving aside any debate whether the early English law merchant was part of a ius gentium or not - it is manifest that abolition of the concept of 'law merchant' will have no effect on the development of any international, transnational or global law;

- International Trade Practices. These can become part of English law by way of treaty (convention) or by being part of UK legislation. ${ }^{1085}$ It has never been asserted (as far as I am aware) that such treaties or legislation was part of the English law merchant, which has related to mercantile 'customs' both in early times and since. Similarly, contracts between parties may expressly, or impliedly, import trade practices and usages into the contract, making them terms thereof. Suffice to say that, abolition of the concept of the 'law merchant' will not affect this, since it operates by way of contract, not custom;

- Custom \& Usage. Abolishing the concept of the law merchant would not prevent the English courts recognizing mercantile customs or usages in the future, in accordance with Goodwin v Robarts (1875). 1086 However, it is (one would assert) unlikely that the courts would now recognize any new mercantile (or maritime) customs or usages (even more so, customs of London or those of other towns or cities) since such matters can be more easily dealt with in legislation or by way of contract. Thus, for example, it is possible that the English courts might recognize the negotiability of new financial instruments. However, this is more likely to occur (if at all) by way of legislation or through contract (see also 29).

\section{CONCLUSION \& POSTCRIPT}

Mansfield CJ (in 1782) noted that:

In all mercantile cases there are two objects, convenience and certainty. ${ }^{1087}$

This should apply generally to English commercial law. The Law Commission has the laudable object of simplifying the law and this would be helped in the commercial sphere by abolishing the concept of the law merchant. Would anyone object? Did anyone object to the abolition of market overt? Would any one regret its passing? In conclusion, the law merchant should be abolished, something which can be achieved without difficulty. ${ }^{1088}$

By way of postscript - in this analysis of the law merchant - review has been made of the Bills of Exchange Act 1882. This is an area of law which might also, usefully, be looked at by the Law Commission, both in respect of: (a) abolishing the anomaly of the need to note, and protest, foreign $\mathrm{BOE} ;{ }^{1089}$ and (b) to consider whether inland

\footnotetext{
${ }^{1081}$ Berger, $\mathrm{n} 989, \mathrm{p} 1$ 'Since the beginning of the 1960s, the protagonists of a transnational world trade law have advocated the existence of a new law merchant, the modern lex mercatoria.'

1082 See e.g. C Schmitthoff, International Business Law: A New Law Merchant, Current Law and Social Problems 1961 , p 129 et seq. See also Trakman, n 39 and texts referred to in Baker II, n 38, p 1266, n 16.

1083 This is discussed in detail in Berger, $\mathrm{n} 989$.

${ }^{1084}$ Baker, n 38 and articles in Piergiovanni, see n 41.

1085 See n 15.

1086 See ns 975 and 977 (text).

1087 Medcalf $v$ Hall (1782) 3 Doug 113 (99 ER 566) at p 113. Also, 'Nothing is more mischievous than uncertainty in mercantile law...Convenience the basis of mercantile law.' Also, Vallejo $v$ Wheeler (1774) 1 Cowp 143 (98 ER 102 ) at p 153 'In all mercantile transactions the great object should be certainty.' See also Lockyer v Offley (1786) 1 TR 252 (99 ER 1079) at p 259 per Willes J 'in all commercial transactions the great object is certainty.' See also Rogers, n 12, pp 211 \& 214 and Coquillette, n 13 , p 291.

1088 viz (1) The legal concept of the 'law merchant' is abolished; (2) references to the 'law merchant' in the (i) Bills of Exchange Act 1882, s 97(2); (ii) Marine Insurance Ac 1906, s 91(2); and (iii) Sale of Goods Act 1979, s 62, are hereby repealed.'

1089 See GS McBain, Modernising the Law on Notarisation and Public Notaries [2016] Journal of Business Law 91-114.
} 
BOE should be abolished. ${ }^{1090}$

${ }^{1090}$ Inland BOE are those: (a) drawn and payable in the British islands; or (b) drawn in the British Islands on a person resident there. All other BOE are treated as foreign BOE. See Bills of Exchange Act 1882, s 4. The British Islands means any part of the UK, including the Isle of Man, Guernsey, Jersey, Alderney and Sark. Given modern electronic payment systems such as SWIFT as well as direct debts, credit cards, debit cards etc; one would suggest that that: (a) must be very rare now and (b) also rare. Like cheques, which the Government is keen to get rid of, BOE suffer from similar problems in respect of: (i) potential for fraud (especially when indorsed); (ii) legal complexity; (iii) administration; (iv) lack of demand. Foreign BOE are still used in export credit transactions. For the decline in cheques, see Payments Council, UK Cheques 2014. See also C Murray et al, Schmitthoff: The Law and Practice of International Trade (12 ${ }^{\text {th }}$ ed, 2012), ch 9. 


\section{APPENDIX A - CHANGING DESCRIPTION OF 'MERCHANT'}

\section{(a) $\underline{17^{\text {th }} \text { Century }}$}

Coke (1611)

Godolphin (1661)

Blount (1674) $)^{1092}$

Malynes (1686)

\section{(b) $18^{\text {th }}$ Century}

Holt CJ (1705)

Cowell (1708)

Jacob (1729)

Beawes (1752)
In Hamond v Jethro (1611) ${ }^{1091}$ shopkeepers were treated as merchants. The casewriter cited Coke CJ as stating that: 'the are four sorts of merchants, that is, merchant adventurers, merchants dormant, merchants travelling, and merchants residents, and amongst them all there shall be no benefit by survivor. Jus accrescendi inter mercatores locum non habet.'

A View of the Admiral Jurisdiction (1661) 'not every one that buys and sells, is ...to be denominated a merchant, but he only who in the way of trade and negotiation deals in movables for gain or profit, upon design of disposing thereof in the way of commerce either by importation, exportation, or otherwise, in the way of emption, vendition, barter, permutation, or exchange. So that he is not properly said to be a merchant, who once and no more does buy commodities that he may sell the same, for it is not one act that does denominate a merchant, but a certain assiduity or frequent negotiation in the mystery of merchandising, unless he be matriculated or entered as such in the society or corporation of merchants. He also may be said to be a merchant, who by common fame and in the opinion of men is commonly reputed a merchant. They that buy wares or merchandizes to reduce them by their own art or industry into other forms than formerly they were of, are reputed rather artificers than merchants; unless by their order they are so transformed by the art and industry of others upon design of selling the same to gain thereby, in which case they may be said to be rather merchants than craftsman or artificers. And such as buy wares for present money, that without altering the form thereof they may sell the same at a future day of payment at a far dearer price than they were bought, are reputed rather usurers than merchants. But bankers, money changers, and such as deal by way of exchange are reputed under the notion of merchants. For whereas it is formerly said that a merchant deals only in movables, understand that money is comprised under that notion. So also are ships.'

Glossographia (1674). Mercable (mercabilis) that may be bought. Mercative (mercativus) belonging to chapmanry. Mercature (mercatura) the trade of merchandise.'

Consuetudo vel Lex Mercatora or the Ancient Law Merchant $\left(3^{\text {rd }}\right.$ ed, 1686), "he that continually deals in buying and selling of commodities, or by way of permutation of wares at home and abroad in foreign parts, is a merchant.' 1093

The Mayor etc of London $v$ Wilks (1705) 2 Salk 445 (91 ER 386). The word merchant includes all sorts of traders, as well and as properly as merchant adventurers.

A Law Dictionary or the Interpreter of Words and Terms (1708)(Mercandisa) 'All goods and wares exposed to sale in fairs and markets...And therefore the word mercator was not restrained, as it seems now to be, to merchants or traffickers in foreign commodities, but extended to all sorts of traders, or buyers and sellers, 1094

Law Dictionary $\left(1^{\text {st }}\right.$ ed, 1729)(merchant, mercator), 'Is one that buys and trades in any thing. And as merchandise includes all goods and wares exposed to sale in fairs or markets, so the word merchant formerly extended to all sorts of traders, buyers and sellers. But everyone that buys and sells is not at this day under the denomination of a merchant, only those who traffic in the way of commerce, by importation or exportation, or carry on business by way of emption, vendition, barter, permutation, or exchange, and which make it their living to buy and sell, by a continued assiduity, or frequent negotiation, in the mystery of merchandizing, are esteemed merchants. Those that buy goods, to reduce them by their own art or industry, into other forms than they are of, and then to sell them, are artificers and not merchants. Bankers and such as deal by exchange, are properly called merchants. ${ }^{1095}$

Lex Mercatoria Rediviva or the Merchant's Directory ( $1^{\text {st }}$ ed, 1752), 'The term merchant (in latin mercator) or trader, from tradendo... is in England, according to the general acceptation of the word, now confined to him who buys and sells any commodities in gross, or deals in exchange, that traffics in the way of commerce, either by importation, or exportation, or that carries on business by way of emption, vendition, barter, permutation, or exchange, and that makes a continued assiduity or frequent negotiation in the mystery of merchandising his sole business. It is true, that formerly every one who was a buyer or seller, in the retail way, was called a merchant, and they continue to be deemed so still, both in France and Holland, but here shopkeepers, or those who attend fairs and markets, have lost that appellation. ${ }^{1096}$

1091 (1611) 2 Brown 99 (123 ER 836).

1092 T Blount. Glossographia ( $1^{\text {st }}$ ed, 1656; 4th ed, 1674).

1093 See $n 799$.

${ }^{1094}$ See also n 803

${ }^{1095}$ See n 847.

${ }^{1096}$ See n 848 
Rolt (1756)

Molloy (1769)

Comyns (1792)

\section{(c) $19^{\text {th }}$ Century}

Montefiore (1803)

Potts (1815)
A New Dictionary of Trade and Commerce ( $1^{\text {st }}$ ed, 1756). 'A general term, signifying a person occupied in some commercial employment, for the purchase, sale, and exchange of commodities; by wholesale or retail, by land, or by sea, or both conjointly.' 1097

De Jure Maritimo et Navali or a Treatise of Affairs Maritime and of Commerce $\left(9^{\text {th }}\right.$ ed, 1769). 'Every one that buys and sells is not from thence to be denominated a merchant, but only he who traffics in the way of commerce, by importation or exportation, or otherwise in the way of emption, vendition, barter, permutation, or exchange, and which makes it his living to buy and sell, and that by a continued assiduity, or frequent negotiation in the mystery of merchandizing. But those that buy goods to reduce them by their own art in industry into other forms than formerly they were of, are properly called artificers, not merchants...but persons buying commodities, though they alter not the form, yet if they are such as sell the same at future days of payment for greater price than they cost them, they are not properly called merchants, but are usurers, though they obtain several other names, as warehouse-keepers, and the like, but bankers, and such as deal by exchange, are properly called merchants.'

Digest. And, generally, every one shall be a merchant who traffics by way of buying and selling, or bartering of goods or any merchandise within the realm, or in foreign parts. ${ }^{1098}$

A Commercial Dictionary (1803) (merchant) 'a person who buys and sells commodities in the gross, or who traffics commercially by exporting or importing for his own account. The word was formerly of a different meaning in this country from what it is now; retail dealers were then called merchants, as they are in France and Holland still; but in this country those who sell retail, with a few exceptions, have lost that appellation. The transacting mercantile business does not constitute a merchant. Those who buy, sell, export, and import for the account and at the risk of others, are called agents, factors, and bankers. Those who transact business, by keeping goods ready in their possession, are termed warehousemen, though they do not sell by retail; yet, in some cases, those who do deal in retail transactions, such as coal merchants, wine merchants, hop merchants, timber merchants, etc. etc. are honoured with that appellation. ${ }^{1099}$

A Compendious Law Dictionary (1815)(merchant) 'every one who buys and sells, is not to be denominated a merchant, but only he who traffics in the way of commerce by importation or exportation, or otherwise in the way of emption, vendition, barter, permutation, or exchange, and who makes it his living to buy and sell.'

${ }^{1097}$ See $\mathrm{n} 846$.

1098 This is the 3rd edition. The first edition of Comyns, Digest was 1762-67 (5 vols). Comyns cited Holt CJ in The Mayor etc of London v Wilks (1705) 2 Salk 445 (91 ER 386).

${ }^{1099}$ See n 954. 


\section{APPENDIX B - HISTORY OF THE LAW MERCHANT}

\section{(a) Position 1066-1290}

Exchequer of the Jews 1194

Bracton (c. 1240)

Lex Mercatoria (c. 1280)

Britton (c.1290)

Fleta (c.1290)

Weights \& Measures

Statute of Acton Burnell 1283

Statute of Merchants 1285

\section{(b) Position 1290-1621}

Carta Mercatoria 1303

Statute of the Staple 1353

Piepowder Courts - Fairs

Gilds

Davies (c.1614-21)
This Ordinance applied to Jewish merchants. It ended in 1290 with the expulsion of the Jews.

Summons \& Attachment. (a) 'because of persons who ought to have swift justice, as merchants, to whom justice is done piepowder...the time of summons is shortened and sometimes provides a period of less than [15] days;(b) 'the formal order of attachments need not always be observed in personal actions, sometimes because of the privilege and favour of crusaders, whose affairs call for thorough and immediate consideration. Similarly because of the privilege and favour of merchants [mercatorum].' As to (a), a shorter period also applied to others. As to (b), by the reign of Edward I (1272-1307), the position of merchants was the same as other plaintiffs.

3 Differences. "the law of the market differs from the common law...in three general ways.. First, it generally delivers itself [of a judgment] more quickly... Second, whoever pledges someone to answer for a trespass, covenant, debt, or detinue of chattels pledges the whole debt, damages, and costs of the plaintiff, if the one pledged is convicted and does not have enough [to pay the judgment] within the bounds of the market. And if one pledged happens to be first attached by gage or by chattels and afterwards he takes the gage away, [and] the market reeve lets him take it outside the bounds of the market on account of such a pledging, the pledge should answer [to] the court or the plaintiff for a gage of this sort or its value...Third...it does not admit anyone to [wager of] law on the negative side, but in this law it always belongs to the plaintiff to prove, for example, by suit or deed or both, and not to the defendant.'

As to these: (a) speedy courts existed for London citizens since 1268 and, thus, were not just the privilege of merchants. For piepowder courts, see below; (b) pledge of entire debt, this was linked to piepowder courts, see below; (c) no wager of law also applied to London citizens and not just to merchants (see n 218, re tally). Wager of law was abolished in 1833

Weighing Drv Goods - Merchants' Measure. 'Merchants nevertheless shall have their weights as far as regards avoirdupois according to their customs.' This exception ended with the Statute of the Staple 1353, which provided for standard measures.

Seller Backing Out of Sale after Earnest Paid. "if ...the seller...regrets what he has done, he shall give the buyer double what he has received by way of earnest, unless this conflicts with the custom of merchants, which lays it down, in accordance with the law merchant, that [he] is either to deliver to the buyer the thing bought or to pay [5s] for every farthing of earnest money.' This became part of the common law and then legislation, see Statute of Frauds 1677, s 17 (see n 249).

Assizes on these (and penalties) applied generally to merchants and non-merchants. The Assize of Weight and Measures, the Assize of Bread and Ale and the Assize of the Pillory (all c. 1266), were repealed in 1863.

Registration of Recognizances of Debt. First limited to merchants, it was availed of by non-merchants from the $14^{\text {th }}$ century. This Act was repealed in 1863 .

Ibid.

Speedy process for Foreign Merchants. This charter emphasised speedy process for merchants. It probably lapsed in 1327 . In expired by 1809 at the latest.

Registration of Recognizances of Debt. First limited to merchants, it was availed of by non-merchants from the $14^{\text {th }}$ century and the right to so register was accepted in an Act of 1531. It was repealed in 1863.

These courts may have commenced c.1221 (in London) or before. By 1466 merchants acted as assessors and not as judges. By 1612 (if not considerably before), these courts were also used by nonmerchants. Piepowder courts became obsolete, in the main, by the $18^{\text {th }}$ century. The Administration of Justice Act 1977 prevented any continuing to operate.

Most were in decline by $16^{\text {th }}$ century. The last gild was said to have been held in 1882 (Preston).

7 Differences. Davies cited the following as differences between the law merchant and the common law: (a) partners, a duty to account re merchants; (b) partners, a survivorship rule re a merchant; (c) letters of reprisal; (d) wager of law on a debt in a simple contract; (e) suit not on a deed could be brought by a merchant on a BOE, bill of lading, insurance policy etc.; (f) Statute of Merchants 1285 and Statute of the Staple 1353;(g) exception re alien merchants that the Crown could not take their stolen goods as waif. As to these: (a), (b) \& (e) became part of the common law (and (a) applied to executors also under the Statute of Westminster 1285); (c) \& (f) applied not just to merchants (and were almost obsolete when Davies 
wrote); (d) wager of law was abolished in 1883 but was in decline in the $16^{\text {th }}$ century; $(\mathrm{g})$ was a common law interpretation corollary to Magna Carta, ch 41 rather than any custom. It is noteworthy that Molloy $\left(2^{\text {nd }}\right.$ ed, $\left.1677, p 437\right)$ only referred to (a) and (b).

\section{(c) Admiralty}

Local Maritime Courts

Vice-Admiralty Courts

High Court of Admiralty

Laws of Oleron

Rhodian Law
Most of these were redundant by the $16^{\text {th }}$ century and all were abolished in 1835 save for the Cinque Ports' Court of Admiralty which has not sat since 1914 and is obsolete.

These courts became obsolete c. 1800 . Technically, they still exist.

This court (c. 1360-1875) became part of the High Court in 1875.

Said to be legislation of Richard I (1189-99). By 1786, 'long ago grown obsolete.' ${ }^{1100}$

Also, Laws of Visby, Mare del Consolato, Amalfitan Table etc. These foreign laws were not directly applicable in English law. They were obsolete by the $19^{\text {th }}$ century.

\section{(d) BOE \& Promissory Notes}

BOE

Promissory Note
The first reported case on a BOE is said to be 1602. By 1692, the courts held that a merchant did not need to be involved for an action to be brought on a BOE. Most usages of merchants on BOE's had been accepted by the courts by 1710. See now Bills of Exchange Act 1882. Reference to any 'law merchant' seems not to have been pleaded since then.

The first reported case on a promissory note is said to be 1663 . By 1704 , their negotiability was recognised. See now Bills of Exchange Act 1882. Reference to any 'law merchant' seems not to have been pleaded since then.

\section{Copyrights}

Copyright for this article is retained by the author(s), with first publication rights granted to the journal.

This is an open-access article distributed under the terms and conditions of the Creative Commons Attribution license (http://creativecommons.org/licenses/by/4.0/).

\footnotetext{
${ }^{1100}$ See n 638 .
} 